UNIVERSIDADE DE SÃO PAULO INSTITUTO DE GEOCIÊNCIAS

\title{
DESCRIÇÃO DE UM COMPORTAMENTO HIDROLÓGICO NÃO USUAL DE UMA LAGOA NA FORMAÇÃO RIO CLARO, SÃO PAULO
}

\author{
RAFAEL KENJI TERADA
}

Orientador: Prof. Dr. Ricardo César Aoki Hirata

\author{
Dissertação de Mestrado
}

Programa de Pós-Graduação em Recursos Minerais e Hidrogeologia

São Paulo

2015 
Ficha catalográfica preparada pelo Serviço de Biblioteca e Documentação do Instituto de Geociências da Universidade de São Paulo

Terada, Rafael Kenji

Descrição de um comportamento hidrológico não usual de uma lagoa na Formação Rio Claro, São Paulo. / Rafael Kenji Terada. - São Paulo, 2015. 121p. : il. + anexos

Dissertação (Mestrado): IGc/USP

Orient.: Hirata, Ricardo César Aoki

1. Águas subterrâneas 2. Lagoas I. Título 
À minha Família. 


\section{SUMÁRIO}

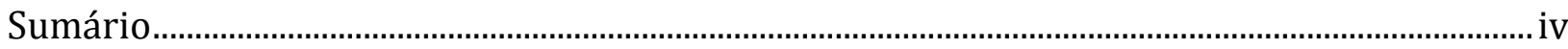

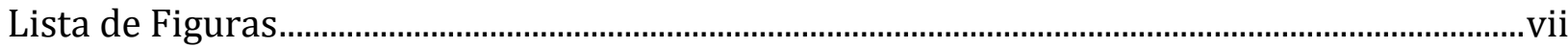

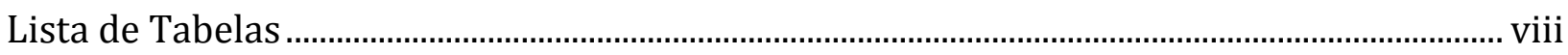

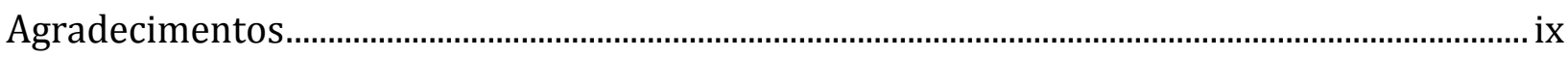

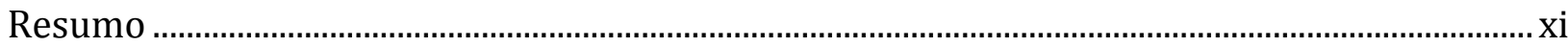

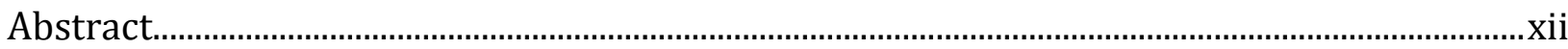

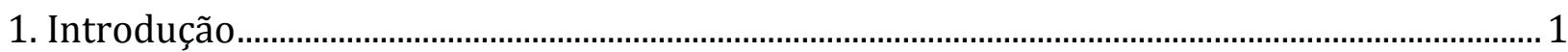

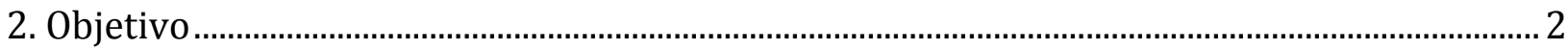

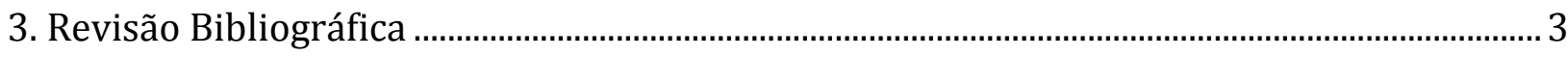

3.1. Interação entre águas subterrâneas e águas superficiais ..................................................... 3

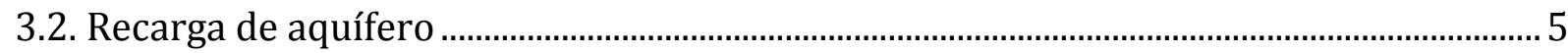

3.3. Métodos de estimativa de recarga ....................................................................................... 7

3.3.1. Método do balanço hídrico …...........................................................................................

3.3.2. Método da flutuação dos níveis de água do aquífero ................................................. 11

3.3.3. Aproximações darcynianas........................................................................................... 13

3.3.4. Método baseado em técnicas isotópicas........................................................................... 14

3.4. Uso agrícola da água ........................................................................................................... 18

3.4.1. Cultura de cana-de-açúcar .......................................................................................... 18

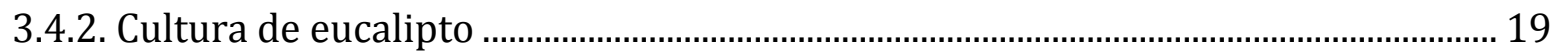

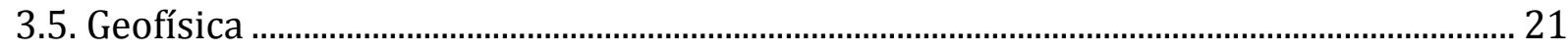

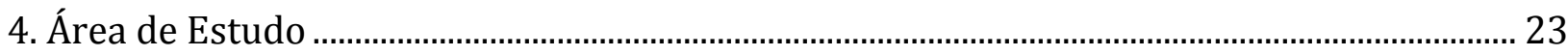

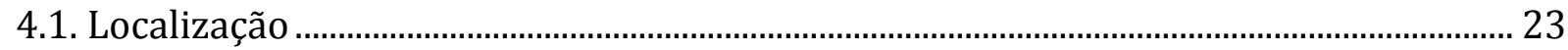

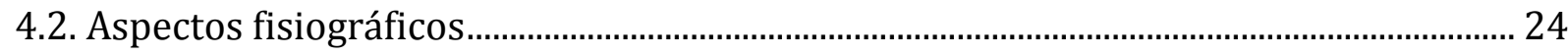

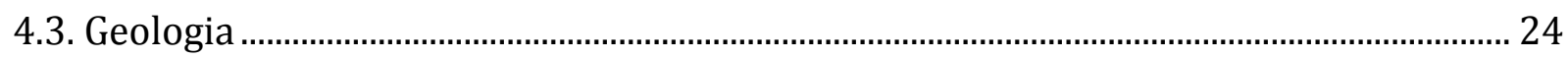

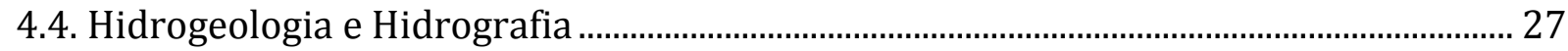

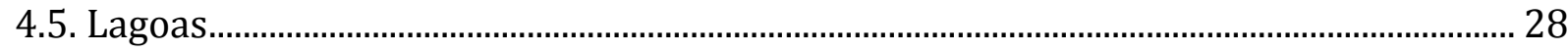


4.6. Aspectos da hidroquímica da Formação Rio Claro ……...................................................... 31

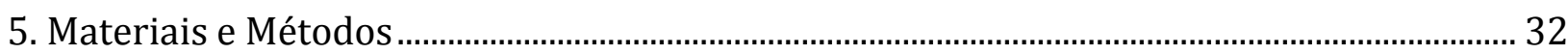

5.1. Perfuração de poços de monitoramento ………................................................................ 32

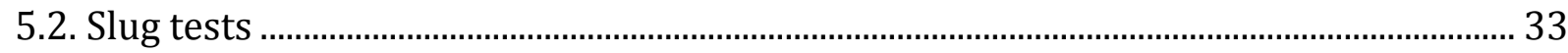

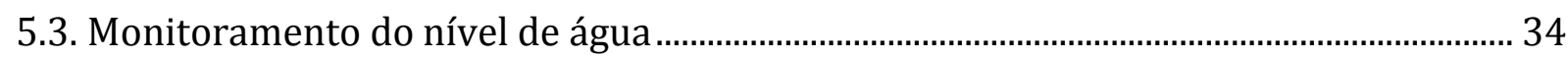

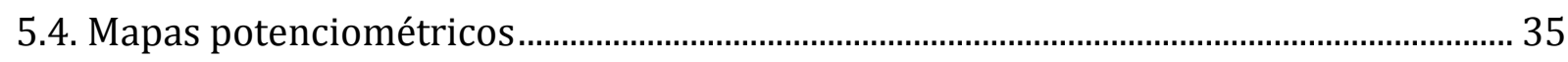

5.5. Coleta de água e análises físico-químicas e isotópicas e análises químicas.................. 35

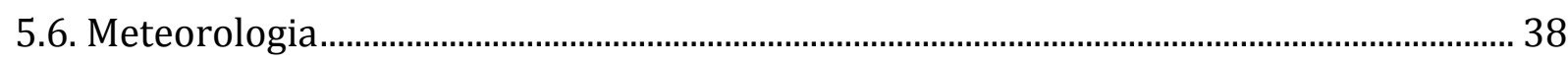

5.7. Cálculo de estimativa de recarga ...................................................................................... 38

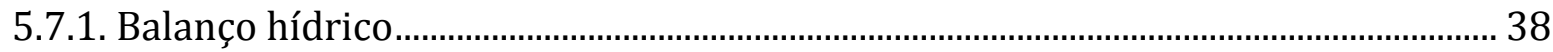

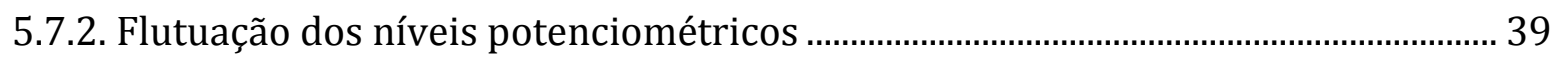

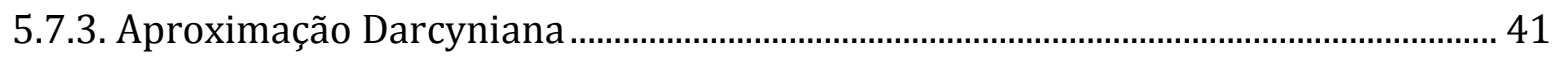

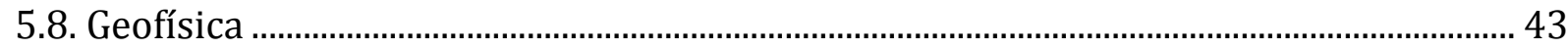

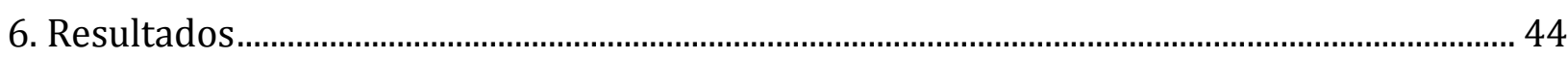

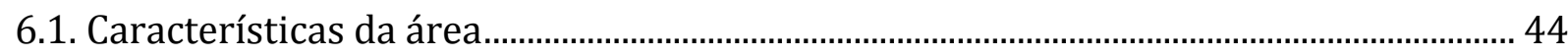

6.2. Fluxo das águas subterrâneas......................................................................................... 47

6.2.1. Avaliação da variação dos níveis dos poços no tempo com as chuvas ................... 47

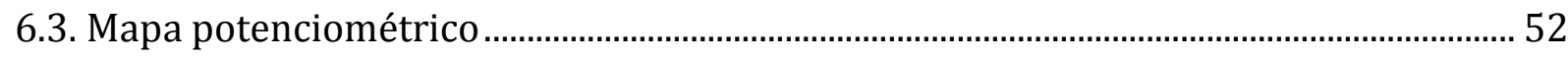

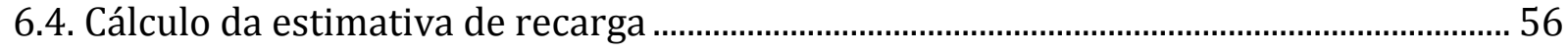

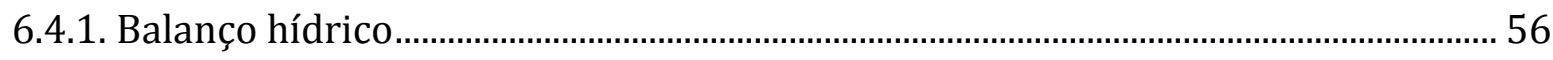

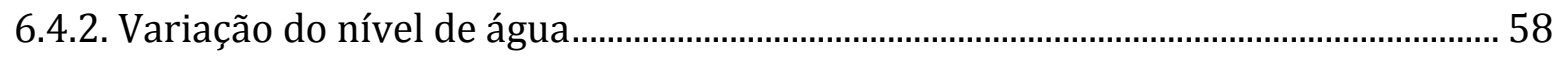

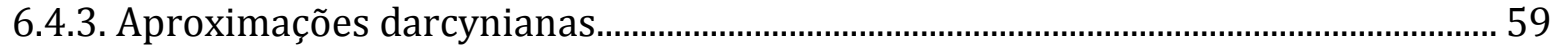

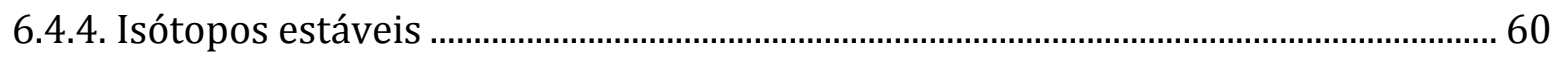

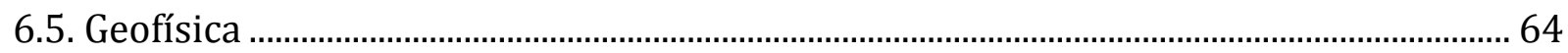

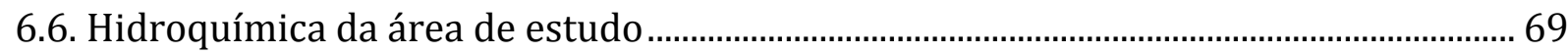

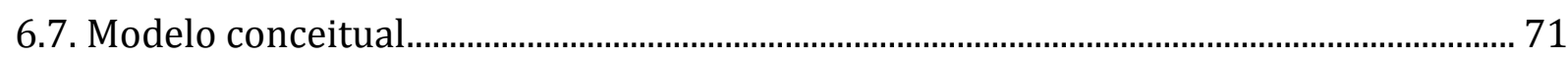

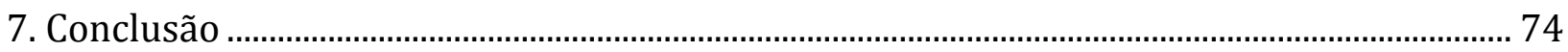

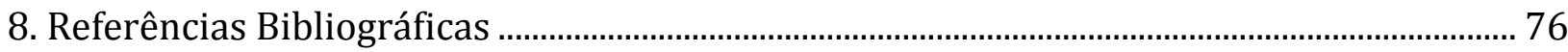




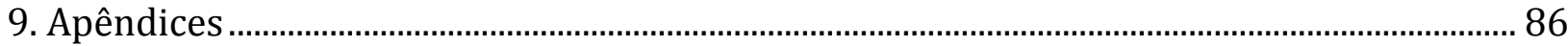

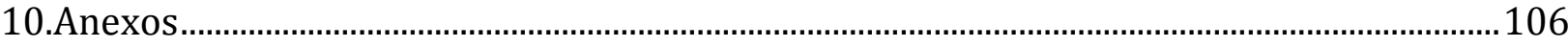




\section{LISTA DE FIGURAS}

FIGURA 1. REPRESENTAÇÃO DA VARIAÇÃO DO NÍVEL DE ÁGUA E OBTENÇÃO DO PARÂMETRO $\triangle H$.

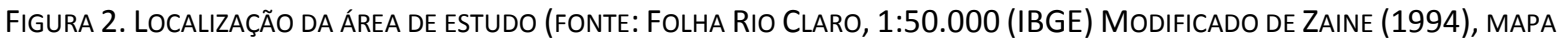
TOPOGRÁFICO DA ÁREA, 1:50.000 (IBGE, 1969))

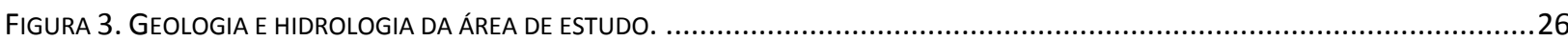

FIGURA 4A. SONDAGEM POR TRADO MECANIZADO; 4B AMOSTRA DO SOLO; 4C LAGO E 4D POÇO 20.........................................32

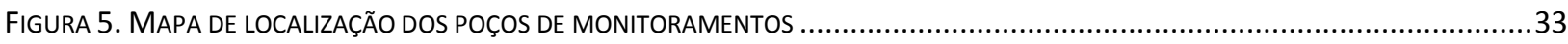

FIGURA 6. TOPOGRAFIA DA ÁREA DE ESTUDOS SOBRE IMAGEM GoOGLE (2012) …........................................................4

FIgURA 7. RELAÇÃo dA PRECIPITAÇÃO E TEMPERATURA NA ÁREA DE ESTUdo (ESTAÇÃO METEOROLÓGICA CEAPLA/UNESP/IGCE, RIO

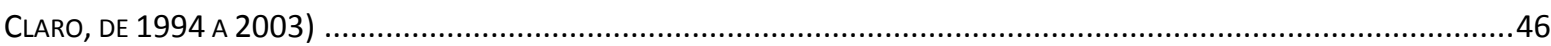

FIGURA 1. VARIAÇÃO TEMPORAL DO NÍVEL DE ÁGUA EM POÇOS DE MONITORAMENTO E A RECARGA POTENCIAL DE ESTUDO............... 48

FIGURA 9. VARIAÇÃO DE PRESSÃO/ NÍVEL DE ÁGUA E CONDUTIVIDADE ELÉTRICA DO POÇO H ......................................................49

FIGURA 10. VARIAÇÃO DE PRESSÃO/ NÍVEL DE ÁGUA E CONDUTIVIDADE ELÉTRICA DO POÇO G...................................................50

FIGURA 11. VARIAÇÃO DE PRESSÃO/ NÍVEL DE ÁGUA E CONDUTIVIDADE ELÉTRICA DO POÇO P .....................................................52

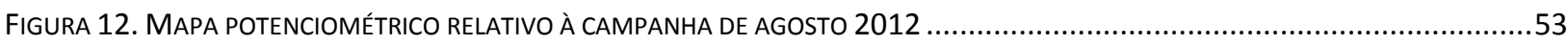

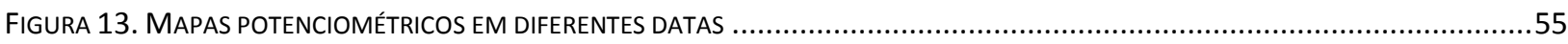

FIGURA 14. GRÁFICO DO BALANÇO HÍDRICO PARA O PERÍODO DE DEZEMBRO 2011 A NOVEMBRO 2012 ........................................57

FIGURA 15. GRÁFICO DO BALANÇO HÍDRICO PARA O PERÍODO DE JANEIRO 2013 A DEZEMBRO 2013 ...........................................58

FIGURA 16. GRÁFICO PARA O CÁlCULO dE RECARGA do POÇO A UTILIZANDO-SE DO MÉTODO DE VARIAÇÃo dE NÍVEL DE ÁGUA............59

FIGURA 17. RELAÇÃo ENTRE 180 E 2H(D) DOS EVENTOS DE CHUVAS EM PIRACICABA E A RETA METEÓRICA LOCAL NO PERÍODO ENTRE 1989 e 1998 (DAdOS De IAEA - INTERNATIONAL ATOMIC ENERGy AGENCY, HTTP://WWW-NAWEB.IAEA.ORg/NAPC/ IH/IHS_RESOURCES_ISOHIS.HTML).

FIGURA 18. RETA METEÓRICA LOCAL, ALINHAMENTO DAS ÁGUAS SUBTERRÂNEAS LOCAIS E ÁGUA DA LAGOA, MOSTRANDO QUE ESTA É O RESULTADO DA EVAPORAÇÃO DE ÁGUAS DA CHUVA E A MÉDIA PONDERADA COM A CHUVA, A PARTIR DOS DADOS DA CHUVA.........62

FIGURA 19. VALORES DAS RAZÕES ISOTÓPICAS NA RETA DE EVAPORAÇÃO DOS POÇOS DE MONITORAMENTO, SEGUNDO A DISTÂNCIA DA LAGOA (VER MAPA ASSOCIADO DA FIGURA 21)

FIGURA 2. AgRUPAMENTO DOS POÇOS SEGUNDO A ASSINATURA ISOTÓPICA DE SUAS ÁGUAS (VER FIGURA 20).............................64

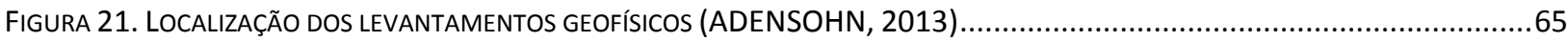

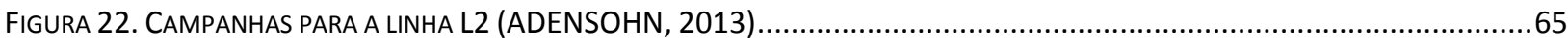

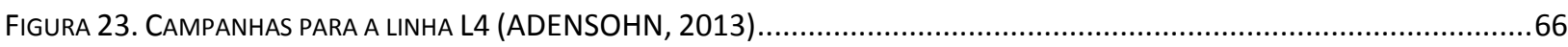

Figura 24. CuRVA da SEV 10, Ao lado do Poço de MONitoramento “O” E TABela de RESUltados (ADENSOHN, 2013) .........68

FIGURA 25. CURVAS DE ISOVALORES DE MILIVOLTS (MV) REFERENTES AOS DADOS DO LEVANTAMENTO DO POTENCIAL ESPONTÂNEO (SP) COM INTERPOLAÇÃO DAS DIREÇÕES DE FLUXO SUBTERRÂNEO (ADENSOHN, 2013).

FIGURA 26. DIAGRAMA DE PIPER CORRESPONDENTE AO TIPO DE HIDROQUíMICO DA FORMAÇÃo RIO CLARO EM POÇOS DE MONITORAMENTO. NOTA: TRACEJADO AZUL: CANA-DE-AÇÚCAR; VERMELHO: LAGOA; VERDE: EUCALIPTO...............................70

FIGURA 27. MOdELO CONCEITUAL DA ÁREA DE ESTUdOS - CORTE B-B' - NÍVEL DE ÁGUA EM PERÍOdO DE ESTIAGEM.........................72

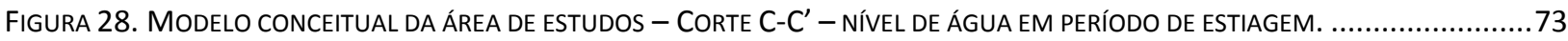




\section{LISTA DE TABELAS}

TABELA 1. MÉTODOS DE ESTIMATIVA DE RECARGA POR ORIGEM DE DADOS (LERNER, 1990)..................................................

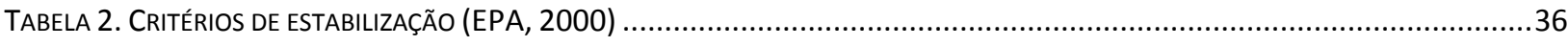

TABELA 3. TABELA DE ERRO VS. CONDUTIVIDADE ELÉTRICA - CUSTÓDIO E LLAMAS (1976) ........................................................37

TABELA 4. VAZÃo ESPECÍFICA EM \% (MODIFICADO DE JOHNSON, 1967, APUD FETTER, 2001) ...............................................40

TABELA 5. VALORES do CÁlCULO dA RECARGA E EVAPOTRANSPIRAÇÃo PELO MÉTOdO DE THORNTHWAITE, DEZEMBRO 2011 A NOVEMBRO

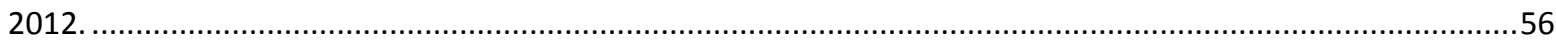

TABELA 6. VALORES do CÁlCULO dA RECARGA E EVAPOTRANSPIRAÇÃo PELO MÉTOdO DE THORNTHWAITE, JANEIRO 2013 A DEZEMBRO

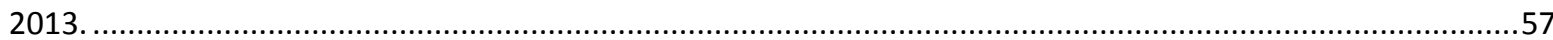

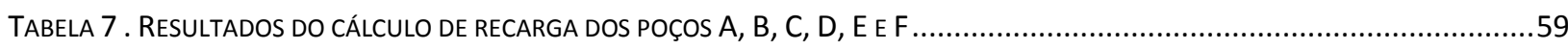

TABELA 8. CÁlCULO dA ESTIMATIVA de RECARGA PELO MÉTOdo dE APROXIMAÇÃo DARCYNIANA ...............................................60

TABELA 9. RESULTADO DO CÁLCULO DE ESTIMATIVA DE RECARGA COM TRÊS TÉCNICAS DIFERENTES................................................60

TABELA 10. RELAÇÃO DAS PROFUNDIDADES DOS ESTRATOS GEOELÉTRICOS EM CADA SEV REALIZADA. NíVEL de ÁGUA APARENTE ENTRE

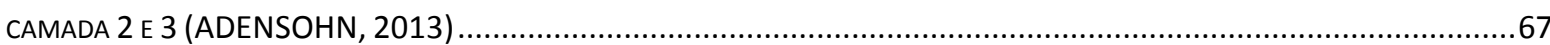




\section{AGRADECIMENTOS}

Esta é a oportunidade para eu expressar meu profundo agradecimento às pessoas que apoiaram (e ainda apoiam) a minha jornada, tanto no trabalho, quanto no meu dia a dia.

Sou grato às pessoas e instituições que, de alguma forma, contribuíram com o desenvolvimento do presente trabalho, dentro e fora da Universidade.

Gostaria de começar meus agradecimentos pelo Prof. Dr. Ricardo Hirata que abriu as portas do LAMO para que eu pudesse concretizar meu antigo sonho da pós-graduação. Sou eternamente grato pelas conversas, conhecimentos, liberdade, amizade e, principalmente, pela paciência e orientação.

Agradeço à Fundação de Amparo à Pesquisa do Estado de São Paulo - FAPESP e ao CNPQ pelo auxílio financeiro (Processo 2012/20124-3) e bolsa de estudo.

Agradeço ao CEAPLA - UNESP pelos dados meteorológicos.

Agradeço aos proprietários da área de estudos, Sr. Roberto e Sr. Natal, pela permissão de uso.

Agradeço a todos amigos do LAMO desta geração, sem os quais a convivência seria totalmente sem graça, em especial a Paulo Galvão, Sandra Procell, Bruno Pirilo, John Batista, Lucas Andreata, Glaucia, Mari Bernardino, Guilleume Bertrand e Osvaldo Ally, que contribuíram diretamente ou indiretamente para este trabalho, e também aos das gerações passadas por terem deixado suas contribuições para os seguintes.

Aos professores Alexandra Suhogusoff, Luiz Ferrari, Reginaldo Bertolo, Veridiana Martins, pelos ensinamentos e auxílios, e à Claudia Varnier e ao John (Jonathan Batista), pela discussão, revisão e confecção de figuras.

Aos amigos Fernando Saraiva, Paulinho Lima e Samuca, pela parceria e diversão no dia-a-dia do campo.

Agradeço, à distância, à equipe japonesa do projeto, em especial agradeço aos Professores Norio Tase, Tsutomu Yamanaka e Shin-ichi Onodera pelo trabalho, amizade e hospitalidade.

Aos amigos do curso LIGEA, em especial: Sidney Fernandes (Sidão), Mariza Silva, Ricardinho, Leandro Martins (Mortolito), Pedrão, Raquel Romão e Jessika Rabello, que sempre compram minhas brigas. Sou muito grato por ter vocês!

À turma IQ-2002, por sempre elevarem o nível e serem referências para mim, em especial: Zé Baldinato, Jú Reigada, Gi Testoni, Xandão, Bolo, Chantily, Batata, Ponê, Digão, Redz e Zozó. 
Aos amigos de toda vida, sem os quais minha passagem por esta vida não teria muito sentido até agora: Mayara Fukuda, Fábio Lefort, Vini Chacon, Marco Sabino, Rodrigo Lombardi, Luciana Spegni, Bidu, Fábio Jorge, Fabinho Ferreira, Barbara Marques, Zé Corsini e Luiz Fernando Pereira.

Quero registrar meus agradecimentos à toda minha Família (tios, tias, primos e primas), mas sou grato especialmente aos meus pais, avó e irmãos pelo compromisso com a família, pelo companheirismo, pela parceria de todos os dias, por terem colocado na minha cabeça que vale a pena estudar e terem dado a estrutura necessária para que isso acontecesse: Yoshiyuki Terada (Pai), Mafalda Tiomi Terada (Mãe), Glauco Jun Terada (irmão), Márcia Miyuki Terada (irmã) e Teresa Okano (Bachan).

Obrigado! 


\section{RESUMO}

TERADA, R. K. Descrição de um comportamento hidrológico não usual de uma lagoa na Formação Rio Claro, São Paulo. 2015, 110. Dissertação de Mestrado - Instituto de Geociências, UNIVERSIDADE DE SÃO PAULO, São Paulo, 2015.

Corpos de águas superficiais são conectados às águas subterrâneas, mas nem sempre a direção de fluxo é a esperada, o que pode comprometer o entendimento da hidrologia local. O objetivo deste trabalho foi construir um modelo conceitual de circulação das águas subterrâneas em uma porção do aquífero Rio Claro, em área onde o uso do solo é predominantemente agrícola, com uso de ferramentas hidrogeológicas, hidrogeoquímicas, geofísicas e de hidrologia isotópica, a fim de entender o papel de uma lagoa rasa, que é uma feição comum à Formação Cenozóica Rio Claro. Foram perfurados 7 poços na área de cana-de-açúcar, 21 poços na área de eucalipto e 7 no entorno da área lagoa, inclusive na área adjacente da lagoa, que passaram a ser monitorados de novembro de 2011 à dezembro de 2013. A recarga para a região foi calculada por três métodos para o ano de 2012, resultando em valores elevados: a)variação de nível de água (576 mm/a), cálculo de balanço hídrico do solo $(520 \mathrm{~mm} / \mathrm{a})$ e aproximação Darcyniana (590 mm/a). Os isótopos estáveis de hidrogênio e oxigênio auxiliaram na interpretação da dinâmica do fluxo local, corroborando com os mapas potenciométricos, mostrando claramente que as águas do aquífero ficavam com uma assinatura mais negativa à medida que os poços se afastavam da lagoa, sugerindo um modelo de mescla simples, sendo as águas da chuva e da lagoa os end members. As águas subterrâneas possuem baixa salinidade $(27 \mu \mathrm{S} / \mathrm{cm}), \mathrm{pH}$ ligeiramente abaixo de 7 , e composição bicarbonatada cálcica e, algumas vezes magnesianas. Entretanto, notou-se a formação de diferentes grupos hidroquímicos segundo a ocupação do terreno, sendo aquele associado à cana-deaçúcar o que apresentou as maiores concentrações de nitrato (até 272,64 mg / $\mathrm{L} \mathrm{NO}_{3}{ }^{-}$) e cálcio (até $24,37 \mathrm{mg} / \mathrm{LCa}^{2+}$ ).

Palavras-chave: Água subterrânea, recarga, lagoa, Formação Rio Claro. 


\section{ABSTRACT}

TERADA, R. K. Description of an unusual hydrological behavior of a pond in Formação Rio Claro, São Paulo. 2015, 110. Master's Thesis - Institute of Geosciences, UNIVERSITY OF SÃO PAULO, São Paulo, 2015.

Superficial water bodies are connected to groundwater, but not always the flow direction is the one expected, which can completely be changed by the local hydrology. The objective of this study was to build a groundwater flow conceptual model of in agricultural area of Rio Claro Aquifer (Rio Claro/SP) using hydrogeological, hydrogeochemical, geophysical and isotopic hydrology tools, in order to understand the role of a shallow pond, common to Rio Claro cenozoic Formation. It was drilled seven wells in cane sugar area, 21 wells in the area of eucalyptus and 7 other wells in the lagoon area, including in the lake itself, which began to be monitored from November 2011 to December 2013. The recharge was calculated by three methods for the year 2012, resulting in high values: a) water level variation (576 mm / y), water balance calculation of soil $(520 \mathrm{~mm} / \mathrm{y})$ and darcynian approach (590 mm ( y). The stable isotopes of Hydrogen and Oxygen supported the interpretation of the local flow dynamics, confirming the potentiometric maps, clearly showing that the aquifer water had a more negative signature comparing to the wells, as a consequence of the movement out of the pond. That fact suggests a simple mixture model, with the rain and the pond water as end members.

Groundwater have low salinity $(27 \mu \mathrm{S} / \mathrm{cm}) \mathrm{pH}$ slightly below 7 , and calcium bicarbonate composition and sometimes magnesian. However, it was noted different hydrochemical groups according to land occupation associated with cane sugar that had the highest nitrate concentrations (up to $272,64 \mathrm{mg} / \mathrm{L}$ $\mathrm{NO}_{3}{ }^{-}$) and calcium (up to $24,37 \mathrm{mg} / \mathrm{L} \mathrm{Ca}^{2+}$ ).

Key words: Groundwater, pond, Formação Rio Claro. 


\section{Introdução}

Os estudos de hidrogeologia em áreas rurais no Brasil são ainda bastante inprudente. Poucas são as pesquisas que abordam, em detalhe, a recarga de aquíferos, ou mesmo, que versam sobre as alterações hidrogeoquímicas em diferentes culturas agrícolas.

Estudos hidrogeológicos em áreas agrícolas tornam-se ainda mais importantes em estados como São Paulo, onde a agricultura de alta tecnologia é presente em quase todo o seu território, particularmente para a cultura da cana-de-açúcar e para o reflorestamento com uso de eucaliptos. A cultura de cana-de-açúcar é a principal prática agrícola de São Paulo, cobrindo uma área de aproximadamente 5,2 milhões de hectares, representando $59,46 \%$ da produção nacional (IBGE, 2010). Da mesma forma, o Brasil é o segundo maior produtor de eucalipto do mundo, e São Paulo figura como o segundo estado em sua produção, com áreas de aproximadamente um milhão de hectares (ABRAF, 2013).

A grande importância do compartimento subterrâneo está na manutenção das áreas agrícolas, fornecendo às plantas água e nutrientes necessários para sobreviver. Culturas de pequeno porte, como a cana-de-açúcar, captam água e nutrientes diretamente da zona não saturada, ao passo que as raízes das de porte maior, como o eucalipto, conseguem atingir grandes profundidades, acessando águas subterrâneas, principalmente em tempos de estiagem.

O conhecimento da hidrogeologia fornece ferramentas para gerir recursos hídricos de maneira a impedir ou remediar possíveis contaminações, entre outras. Assim, este mestrado tem como objetivo entender a relação hidrodinâmica de uma lagoa e o aquífero sedimentar livre da Formação Rio Claro, em uma área rural do município de Rio Claro, onde encontram se plantados eucaliptos e cana de açúcar.

Uma característica marcante da área de estudos é a presença de lagos sobre a Formação Rio Claro em divisores de água, posição que fornece um comportamento hidrogeológico não usual, ou seja, menos típico ao corpo de água: o de funcionar como área de recarga do aquífero. 


\section{Objetivo}

O objetivo principal desta pesquisa é a construção de um modelo conceitual de uma porção do Aquífero Rio Claro em uma zona agrícola no município homônimo, com uso de ferramentas hidrogeológicas, hidrogeoquímicas, geofísicas e de hidrologia isotópica e, com isso, entender o papel de lagoas rasas, comuns à Formação Rio Claro, na recarga e circulação das águas subterrâneas. 


\section{Revisão Bibliográfica}

\subsection{Interação entre águas subterrâneas e águas superficiais}

Corpos de águas superficiais são parte integrante do sistema de fluxo de águas subterrâneas, uma vez que a interação ocorre basicamente em todas as paisagens, desde pequenos riachos, lagos, áreas alagadiças e nascentes até grandes rios e costas marítimas.

As águas subterrâneas movem se por fluxos organizados no espaço chamados sistemas de fluxos. Em uma área podem ser identificados múltiplos sistemas de fluxos de diferentes ordens de magnitude, de local a regional, e uma relativa ordem alinhada e hierárquica controladas pela configuração do lençol freático, pela distribuição da condutividade hidráulica da rocha, pelo clima (precipitação como fonte de recarga), tanto quanto da topografia da paisagem (FREEZE e WITHERSPOON, 1967).

Embora se assuma que as áreas topograficamente mais altas são áreas de recarga e as mais baixas de descarga, isso se confirma para os sistemas de fluxo regional (WINTER, 1999). A superposição de sistemas de fluxos locais associados a corpos de águas superficiais em composições regionais resulta em complexas interações entre águas subterrâneas e superficiais pela paisagem, independentemente da posição topográfica.

Processos hidrológicos associados aos corpos de águas superficiais, como altos níveis de água sazonais, evaporação e transpiração da água subterrânea do perímetro das águas superficiais, são as maiores causas das complexas dinâmicas sazonais de fluxos das águas subterrâneas associadas às águas superficiais, e também vêm sendo documentados em outros tipos de ambientes como glacial, dunas, costas, calcáreos e terrenos ribeirinhos (WINTER, 1999).

Essa interação da água subterrânea com lagos, rios, canais e drenagens adjacentes é um aspecto muito importante de muitos dos sistemas hidrogeológicos (BARLOW e MOENCH, 1998), e a chave para entender as diferenças nas condições das lâminas de água é verificar sua continuidade nos arredores nos sistemas de fluxos das águas subterrâneas aos quais pertencem (WINTER, 1998). Se a lâmina de água for contínua e a carga hidráulica for maior que a da lâmina de água do lago, a água subterrânea flui em direção ao lago, funcionando 
como local de descarga; porém, se a lâmina da água do lago for maior que os arredores, o lago cede água, funcionando como uma fonte de recarga. Se o sistema de fluxo nos arredores não for contínuo, a água do lago pode infiltrar para a água subterrânea através da zona não saturada, funcionando também como fonte de recarga.

Nesse sentido, Sena e de Melo (2011) descreveram as relações biogeoquímicas e hidrogeodinâmicas entre uma lagoa vulnerável a pressões antropogênicas e seus afluentes e aquíferos do entorno, utilizando a metodologia baseada em monitoramento mensal de nível d'água e dados hidrogeoquímicos da região combinados com o software VISUAL BALAN v 2.0. Com ele foi possível identificar o complexo comportamento natural do lago Pateira de Fermentelos, Portugal, que durante a maior parte do ano hidrológico comporta se como uma superfície de passagem de água da parte terminal do Rio Cértima até sua confluência com o Rio Águeda. No entanto, sob eventos de chuvas pesadas, o Rio Águe tem seu fluxo de volta para o lago e, em temporadas de estiagem, o rio seca.

Bocanegra et al. (2012) discutiram os processos hidrogeológicos relacionados à interação do lago com a água subterrânea na Planície dos Pampas, Argentina. Nesse estudo, utilizaram-se técnicas de medição do nível de água, Thornthwaite e balanço hídrico para a estimativa da recarga, enquanto os processos hidrogeoquímicos relacionados com a interação entre o lago e a água subterrânea foram avaliados através de técnicas isotópicas, hidrogeoquímicas e modelos numéricos. Os autores concluíram que, a partir da metodologia empregada, foi possível definir e ajustar o modelo conceitual em que o lago apresenta um comportamento influente-efluente, operando tanto como área de recarga e descarga para água superficial e subterrânea.

As interações entre água subterrânea e superficial ficam claras quando se presenciam eventos de investigações hidrogeológicas, como ocorreu no lago Walker, em Nevada, Estados Unidos, aonde as águas veem sendo utilizadas para agricultura nos últimos 90 anos. Niswonger et al. (2014) descreveram que a devido a esse medo de uso, ocorreu a diminuição da água, resultando em um decréscimo de $100 \mathrm{~km}^{2}$ da área superficial e perda da atividade de pesca devido à salinização. Nesse ponto, evidencia-se a importância do conhecimento dos processos hidrológicos de maneira a fornecer respostas realísticas para o gerenciamento 
dos recursos hídricos, como os associados a variações climáticas, uso conjunto da água subterrânea e superficial, e mudanças no uso e ocupação do solo e da água na paisagem.

Outro exemplo de interação entre águas subterrâneas e superficiais é o descrito por Lee et al. (2014). De acordo com os autores, as medidas de campo combinadas com modelos numéricos geraram cenários de fluxo da água subterrânea e processos geoquímicos de controle da mobilidade de arsênio nos aquíferos de água doce na costa. Elevadas concentrações de arsênio foram observadas em uma faixa de 1-2 metros abaixo da linha de costa em duas praias arenosas do lago Eire, Ontário, Canadá. A análise de fases aquosas e sólidas sugeriu que óxidos de ferro presentes abaixo da linha de costa acumulam arsênio, criando risco de altas concentrações desse elemento. Análises do fluxo de água subterrânea combinadas com medições de cargas hidráulicas verticais indicaram que o fluxo de ondas promove uma circulação propícia que condiciona gradientes redox e pH ideais para precipitação de ferro e sequestro de arsênio no aquífero.

\subsection{Recarga de aquífero}

A recarga efetiva é definida como a parcela de água que efetivamente atinge a zona saturada, proveniente de qualquer direção, seja por baixo, por cima ou pela lateral (LERNER, 1997), podendo ocorrer naturalmente a partir de chuva, água superficial, lagos ou de outro aquífero, ou de forma artificial (protagonizado pelo homem) através da agricultura e da urbanização (LERNER, 1990; CUSTÓDIO, 1998).

Lerner (1997) conceituou os principais mecanismos de recarga com relação às fontes, como direta ou difusa para a água adicionada por percolação direta vertical através da zona não saturada, devido ao excesso de umidade do solo descontando a evapotranspiração; recarga indireta como a que percola através do leito de cursos da água superficial; e de recarga localizada como água resultante da concentração de água em superfície na ausência de canais bem definidos.

No entanto, nem toda água que infiltra chega ao aquífero, podendo ficar disponível na zona não saturada do solo para ser absorvida por seres vivos ou evaporar de volta para a atmosfera. Além disso, ela pode ser interceptada por horizontes de baixa condutividade e se 
encaminhar para outras depressões locais próximas, onde escoa e evapora em vez de se juntar ao sistema de água subterrânea regional (de VRIES e SIMMERS, 2002).

Para interpretar e avaliar o processo de recarga deve ser considerado como critério o tempo, pois dependendo da escala adotada, pode-se determinar se, em certo sistema local, a recuperação do reservatório é de curto ou de longo prazo (de VRIES e SIMMERS, 2002), obedecendo a escalas de poucas horas em regiões úmidas, solos muito grossos e nível de água raso, até anos em regiões áridas e níveis de água profundos (FETTER, 2001).

Em áreas rurais, Lerner et al. (1990) consideraram precipitações, rios, águas superficiais, fluxos entre aquíferos e irrigações como fontes de recarga, sendo controladas pela interação com os aspectos fisiográficos. A cobertura vegetal também é relevante para o estabelecimento da recarga de uma área (GEORGE et al. 1999), pois geralmente é maior em áreas não vegetadas do que vegetadas (GEE et al., 1994) e maior em áreas de plantio e pastagens do que em áreas florestadas (PRYCH, 1998, apud SCANLON et al., 2002, p.20).

Scanlon et al. (2002) apontaram que o fator controlador da recarga é o clima, uma vez que existe uma grande diferença nos índices de recarga de regiões úmidas para regiões áridas. Segundo Bouwer (1989) e Tyler et al. (1996, apud MONDIN,2005, p.9), a recarga direta corresponde à faixa de $30-50 \%$ da precipitação em regiões úmidas, de $10-20 \%$ em climas do tipo mediterrâneo e de 0-2\% em climas secos.

Cada região possui particularidades no clima, na fisiografia, na ocupação do solo e na geologia que alteram as porcentagens das recargas efetivas, definidas ao longo de sua história. Custódio e Llamas (1981) entendem isso apontando que as características do terreno como tipo de ocupação do solo, grau de compactação do terreno, inclinação topográfica, granulometria e textura do material de cobertura e de subsuperfície, calor específico e umidade inicial do solo também devem ser considerados, assim como as características do fluido e intensidade da chuva, verificando a espessura da lâmina da água sobre o solo, os gradientes hidráulicos descendentes de infiltração, as perdas pela evaporação e o balanço hídrico. 


\subsection{Métodos de estimativa de recarga}

A estimativa de recarga é uma atividade complexa e engloba importantes fontes de erros, como, por exemplo, variabilidade espacial e temporal das condições hidrometeorológicas. Uma vez feito de forma indireta (LERNER et al., 1990), o controle dos parâmetros é difícil, portanto, recomenda-se a comparação de mais de um método de estimativa, de forma a possibilitar a avaliação global desses fatores e permitir ajustes àqueles cuja avaliação quantitativa apresente maiores discrepâncias (VIVIANI-LIMA, 2007).

Os métodos úteis em uma determinada localidade podem não funcionar em outra, com isso, Custódio (1998) e Samper (1998) recomendam que, para a realização de uma boa estimativa de recarga, deve-se considerar sua magnitude, o erro da estimativa da quantidade de água disponível e quanto desta pode ser convertido em recarga com a maior precisão possível. Segundo os autores, é necessário também conhecer os processos e os mecanismos de recarga da área estudada, já que possibilita a seleção de diferentes técnicas para sua estimativa.

É possível encontrar bons espectros de utilização de métodos de estimativa de recarga subterrânea tanto em áreas urbanizadas como não urbanizadas (LERNER, 1990; SCANLON et al., 2002), desde medidas pontuais com lisímetros (SCANLON et al. 2002; VIVIANI-LIMA, 2007) até cálculos de balanço hídrico de áreas maiores (VASCONCELOS, 1999; MARTINS, 2005; MONDIN, 2005; VIVIANI-LIMA, 2007).

Lerner et al. (1990) separaram tipos de fontes e agruparam de acordo com as origens da água: precipitação, rios, fluxos entre aquíferos, irrigação e recarga urbana; e dentro dessas categorias, foram agrupados como: medidas diretas, balanço hídrico, aproximações darcynianas, técnicas que utilizam traçadores, entre outros métodos.

Mais tarde, Scanlon et al. (2002) adotaram uma divisão das técnicas de estimativas de recarga em categorias que refletem a origem dos dados: águas superficiais, zona não saturada e zona saturada.

A Tabela 1 elaborada por Lerner (1990) resumi os métodos de estimativa de recarga por origem. 
Tabela 1. Métodos de estimativa de recarga por origem de dados (LERNER, 1990)

\begin{tabular}{|c|c|}
\hline Origem do dado & Métodos \\
\hline \multirow{6}{*}{ Águas superficiais } & Balanço hídrico - canal \\
\hline & Permeâmetro \\
\hline & Fluxo de base \\
\hline & Traçador de calor \\
\hline & Traçadores isotópicos \\
\hline & Modelos numéricos \\
\hline \multirow{7}{*}{ Zona Não Saturada } & Lisímetros \\
\hline & Plano de fluxos nulo \\
\hline & Lei de Darcy \\
\hline & Traçadores aplicados \\
\hline & Traçadores históricos \\
\hline & Traçadores ambientais \\
\hline & Modelos numéricos \\
\hline \multirow{5}{*}{ Zona Saturada } & Variação do nível de água \\
\hline & Lei de Darcy \\
\hline & Datação da água subterrânea \\
\hline & Traçador ambiental \\
\hline & Modelos numéricos \\
\hline
\end{tabular}

Segundo Custódio (2002), o cálculo da recarga pode ser muito impreciso, não só porque depende de uma taxa espacialmente e temporalmente variável, que pode ser afetada pelas mudanças de uso do solo, mas também porque depende da extensão superficial, que nunca é clara, principalmente quando existem fluxos laterais e verticais de outros aquíferos.

Mondin (2005) explicou métodos para estimativa em zona não saturada que foram mais aplicados em regiões áridas e semiáridas, onde a zona não saturada é mais espessa, e geraram estimativas do potencial de recarga baseados nas taxas de drenagem abaixo das zonas de raízes e em alguns casos, a drenagem foi desviada lateralmente e acabou não 
atingindo o nível de água. O mesmo autor também afirma que enquanto métodos de zona não saturada geram estimativas pontuais de recarga de zona saturada são capazes de estimar áreas maiores, mostrando evidências diretas de recarga real, pois atingem o nível de água, enquanto os métodos de água superficial e de zona não saturada provêm estimativas de drenagem ou recarga potencial.

Wahnfried e Hirata (2005) afirmam que, para a escolha do método adequado, devese considerar os mecanismos que influenciam a recarga (clima, geologia, geomorfologia), bem como a escala de tempo e espaço que se quer investigar, sem deixar de lado o objetivo do trabalho. Lerner et al. (1990) sugerem que devido à não linearidade do comportamento da recarga, seu estudo deve ser feito por blocos homogêneos, ou seja, a área deve ser dividida em locais com características semelhantes (geologia, morfologia, solos, clima, chuva e vegetação). Cada fator deve ser mapeado em planos diferentes e depois devem ser combinados para produzir um mapa de zonas homogêneas. A recarga deve ser estimada para cada zona.

Dadas as incertezas associadas a cada técnica de estimativa de recarga, a aplicação de dois ou mais métodos de cálculo e sua comparação é a melhor forma de se conseguir uma boa estimativa de recarga.

Para o presente trabalho foram escolhidos os métodos de balanço hídrico, flutuação dos níveis de água, aproximações darcynianas e isótopos estáveis.

\subsubsection{Método do balanço hídrico}

O método de balanço hídrico é baseado em equações que incluem fluxo de água, ou seja, da água que entra (precipitação) e sai (evapotranspiração e escoamento superficial) de uma dada bacia hidrográfica ou do solo. Existem diversas abordagens na literatura, mas, segundo Scanlon et al. (2002), tem-se:

$$
R=P+Q_{o W}^{S W}-R_{0}-E T^{s w}-E T^{u z}-\Delta S^{s n o w}-\Delta S^{s W}-\Delta S^{u z}
$$

Onde: $\mathrm{R}=$ recarga; $\mathrm{P}=$ precipitação; $\mathrm{Q}_{\mathrm{on}}$ e $\mathrm{Q}_{\text {off }}=$ fluxos de água que entram e saem da bacia; $\mathrm{ET}=$ evapotranspiração; $\Delta S$ = variação no armazenamento de água; R0 = escoamento superficial para fora da bacia; sw = água superficial; uz = zona não saturada; snow = neve 
Todos os componentes podem ser medidos, estimados ou calculados. Segundo Scanlon et al. (2002), a vantagem desse método é que ele abrange uma grande faixa de tempo e espaço, variando desde escalas de centímetros e segundos (lisímetro) até quilômetros e séculos (modelos climáticos globais). É um método fácil de utilizar, porém possui diversos erros associados, como, por exemplo, avaliação da evapotranspiração e estabelecimento do escoamento superficial, como fluxos de tempestades ou fortes chuvas tropicais (LERNER et al., 1990). Scanlon (2002) não recomenda a utilização desse método quando a recarga é uma fração muito pequena do balanço hídrico, quando existe alta incerteza associada aos dados e às saídas alternativas da água.

Thornthwaite (1948) definiu evapotranspiração como a combinação de evaporação da superfície do solo e da transpiração das plantas, representando o transporte de água da terra de volta para a atmosfera. Em decorrência, a evapotranspiração potencial pode ser definida como o montante de água que evaporaria se toda a água estivesse disponível. Ele conseguiu determinar esse parâmetro em termos de temperatura (energia solar), sendo por essa razão que esse fator é mais alto nos trópicos. Desde então, tem sido considerado para estimar a recarga.

Amorim et al. (1999) utilizaram o modelo Thornthwaite para estimar a evapotranspiração potencial no Brasil, associado a um Sistema de Informação Geográfica (SIG) e utilizaram um coeficiente de correção para diminuir superestimativas induzidas por temperaturas médias acima de $26,5^{\circ} \mathrm{C}$. Seus resultados mostraram se coerentes com as características climáticas de cada região geográfica do Brasil, sendo os maiores valores de ETP observados nas regiões Centro-Oeste, Nordeste e Norte, e os menores no Sudeste e Sul do país.

Youlton (2013) verificou a modificação no balanço hídrico em escalas diárias na zona não saturada causada pela substituição de pastagem por cana-de-açúcar. Os resultados mostraram que essa substituição no uso do solo aumentou a produção de sedimentos durante o primeiro ano. Depois de quatro meses de crescimento, o dossel de cana-deaçúcar interceptou $40 \%$ da precipitação e o escoamento superficial diminuiu por efeito da palha no solo. A percolação sob a cana-de-açúcar é menor que na pastagem devido à maior evapotranspiração da cultura. 
Barreto (2005) estimou a recarga direta e profunda do Sistema Aquífero Guarani, delimitando a bacia representativa do Ribeirão do Onça (região de Itirapina, SP), analisando paralelamente os comportamentos do aquífero e da evapotranspiração na bacia. Paralelamente, também observou o comportamento do aquífero em diversas culturas, o que permitiu a análise de ambos. O monitoramento mostrou que a recarga do aquífero é menor em solos cultivados com eucalipto que em áreas cultivadas com pastagem. A variação do nível de água apresenta forte correlação com as culturas, exceto com a de eucaliptos. Nessa avaliação da recarga, todos os métodos empíricos, com exceção ao de Thornthwaite, superestimaram a evapotranspiração quando comparados ao valor estimado pelo balanço hídrico. No entanto, o autor aconselhou que é importante ter uma visão cautelosa ao aplicar métodos empíricos e semi-empíricos e só uma avaliação prolongada pode indicar quais os métodos mais se aproximam da realidade.

\subsubsection{Método da flutuação dos níveis de água do aquífero}

Esse método é baseado na relação da variação do nível de água em um aquífero nãoconfinado motivada pela recarga (HALL e RISSER, 1993; HEALY e COOK, 2002). Maziero (2005) afirma que é a técnica mais utilizada para estimar a recarga devido à sua simplicidade e também por apresentar sensibilidade aos mecanismos do movimento da água na zona não-saturada, complementaram Healy e Cook (2002)

A principal premissa desse método é que as elevações nos níveis de água em aquíferos não-confinados devem se à água de recarga subterrânea que vem da superfície. A recarga $(R)$ é estimada pela equação:

$$
R=S_{y_{*}} \Delta h+Q \Delta t
$$

Onde:

$\mathrm{S}_{\mathrm{y}}=$ vazão específica

$\Delta \mathrm{h}=$ variação no nível de água

$\mathrm{Q}$ = vazão de exploração ou perdas; e

$\Delta \mathrm{t}=$ tempo

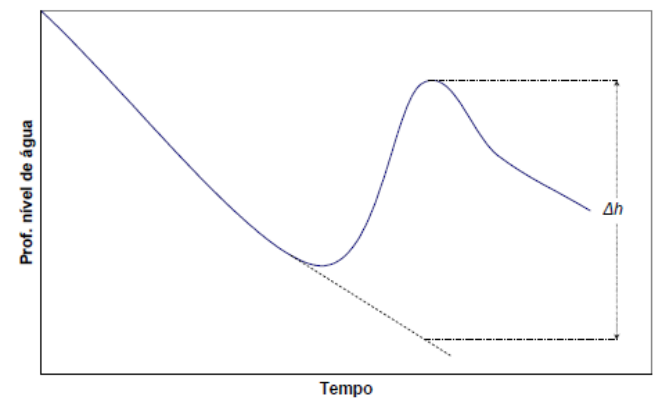

Figura 3 . Representação da variação do nível de água e obtenção do parâmetro $\Delta \mathrm{h}$. 
Healy e Cook (2002) determinaram que cada elevação individual do nível de água corresponde a uma estimativa da recarga total, onde $\Delta h$ é igual à diferença entre o pico de subida e o ponto mais baixo da curva de recessão antecedente e extrapolada até o instante do pico. Essa curva corresponde ao traço que a hidrógrafa do poço de monitoramento teria seguido caso não houvesse o processo de recarga. Essa equação também assume que toda água que entra atinge o armazenamento e que todos os outros componentes do balanço hídrico subterrâneo (evapotranspiração subterrânea, fluxo de base, entrada e saída de fluxo) são iguais a zero.

O método responde melhor para aquíferos rasos, já que o nível de água encontra se próximo à superfície e a recarga é rápida. Os aquíferos profundos, por sua vez, podem não exibir súbitas variações de nível devido à tendência de dispersão das frentes de molhamentos com a distância (HEALY e COOK, 2002; SCANLON et al. 2002). Além disso, as taxas de recargas são muito irregulares dentro de uma mesma bacia por vários motivos que incluem: declividade do terreno, topografia, geologia, entre outros. Dessa forma, uma observação confiável e que represente as fontes de recarga depende do local de perfuração dos poços (HEALY e COOK, 2002).

Caso as taxas de recarga e descarga sejam iguais, não se observará variação do nível de água e o método de flutuação do nível de água acusaria recarga zero (HEALY e COOK, 2002). Segundo Moon et al. (2004), essas flutuações são respostas a muitos fenômenos distintos, e podem não ser indicativas de recarga ou descarga de água subterrânea, podendo ser resultantes de características dos próprios eventos de precipitação (quantidade, duração e intensidade), pressão atmosférica (ARANTES, 2003) e dos fatores hidrogeológicos como topografia, espessura da zona não-saturada, condutividade hidráulica e composição mineral.

A principal dificuldade desse método refere se à determinação de um valor representativo para a vazão específica $\left(S_{y}\right)$, além de separar a proporção relativa à recarga e aquela atribuída a outras origens (flutuações devido à pressão atmosférica, presença de ar preso pela frente de molhamento ou interferência de poços em bombeamento) (SCANLON et al., 2002). Lerner (2002) também alerta quanto à aplicação do método em áreas urbanas, pois recargas urbanas contínuas (por exemplo, fugas das redes de água e esgoto) não causam variações transientes nos níveis de água. 
Mondin (2005) utilizou esse método para quantificar a recarga do aquífero livre e raso no Parque Ecológico do Tietê-SP, com duas abordagens: levando-se em conta variações dos níveis de água causados para cada evento de forte precipitação e variações mensais, ou seja, diferença do nível freático observado entre o começo e o fim do mês pela extrapolação da curva de rebaixamento padrão do aquífero. Adotou o valor de 0,12 para vazão específica de acordo com sua análise granulométrica e obteve faixa de 22 a $92 \%$ em recargas episódicas, 10 a $32 \%$ em recargas mensais e correlação de $80 \%$ entre a recarga por eventos episódicos com a soma das precipitações ocorridas.

Lima et al. (2009) apresentaram uma avaliação quantitativa da recarga aplicada à restinga lagunar da região metropolitana de Maceió-AL, utilizando o método da variação do nível de água. Com precipitação anual em torno de 1900 mm, clima quente e úmido, a cidade vem sofrendo com o aumento da exploração não planejada dos recursos hídricos nos últimos anos, e esse estudo veio ao encontro da necessidade de estudos sistêmicos para avaliação de uso racional e precaução contra riscos de contaminação. Os autores trabalharam com valores do ano de 1994 e do período de 2002-2007, adotaram valor de 0,26 para vazão específica com base no trabalho de Healy e Cook (2002) para o terreno com areia média e chegaram as valores de recarga de 6 a 39\% da precipitação anual.

Neto e Chang (2008) aplicaram esse método com base em monitoramentos de níveis de água realizados entre 2002 e 2005 em poços no Aquífero Rio Claro, no município de Rio Claro, São Paulo, gerando estimativa de recarga anual e da variação do armazenamento em subsuperfície. Foi adotado valor de 0,17 para vazão específica (Sy).

\subsubsection{Aproximações darcynianas}

A lei de Darcy pode ser utilizada para estimar a recarga entre dois pontos, que podem ser poços de monitoramento alinhados perpendicularmente ao fluxo da água subterrânea. A recarga estimada é a soma dos valores positivos encontrados durante o intervalo de tempo considerado. O maior obstáculo é obter valores confiáveis de condutividade hidráulica e gradiente hidráulico.

Onde: 


$$
R=K \cdot i . \Delta t \quad \begin{aligned}
& \mathrm{R}=\text { recarga }(\mathrm{m}) \\
& \mathrm{K}=\text { condutividade hidráulica }\left(\mathrm{m} \cdot \mathrm{s}^{-1}\right) \\
& \mathrm{i}=\text { gradiente hidráulico } \\
& \Delta \mathrm{t}=\text { intervalo de tempo considerado }
\end{aligned}
$$

Mondin (2005) também utilizou esse método para quantificar o processo de recarga do aquífero livre e raso do Parque Ecológico do Tietê, São Paulo, em uma planície aluvionar associada à sedimentação do rio Tietê. O autor concluiu que esse método mostrou resultados significativos quando houve monitoramento diário, já que os resultados mensais foram realizados pela somatória do balanço da massa de água do aquífero.

Como um exemplo de utilização em larga escala, Schrader et al. (2014) conseguiram desenvolver um modelo conceitual de um compartimento de água subterrânea em terreno cárstico, com cerca de 3,390 mega metros cúbicos de água, afetado por mineração profunda de ouro. Essa pesquisa tinha como objetivo determinar se todas as nascentes e rios conseguiriam voltar após drenagem total desse compartimento em resultado do mau gerenciamento sofrido desde o início da atividade, no século passado. Cálculos de recarga foram feitos por aproximações darcynianas, mas a previsão é que continuem secos mesmo depois de preencher os compartimentos. Essa estimativa de recarga é difícil, pois as condições pelas quais ela irá ocorrer no tempo pós-mineração serão diferentes das que passariam no pré-mineração e no presente (recarga natural).

\subsubsection{Método baseado em técnicas isotópicas}

Isótopos de $\mathrm{O}$ e $\mathrm{H}$

Os isótopos a serem utilizados neste estudo relacionam se aos elementos oxigênio e hidrogênio. O oxigênio é um elemento do grupo dos calcógenos, não metálico e altamente reativo. Possui três isótopos estáveis ${ }^{16} \mathrm{O},{ }^{17} \mathrm{O}$ e ${ }^{18} \mathrm{O}$, sendo que os dois mais comuns são o ${ }^{16} \mathrm{O}(99,76 \%)$ e ${ }^{18} \mathrm{O}(0,201 \%)$ (CLARK e FRITZ, 1997). A razão entre esses dois isótopos é aproximadamente 0,002 . 
O hidrogênio é um elemento não metálico, que possui dois isótopos estáveis ${ }^{1} \mathrm{H}$ $(99,98 \%)$ e ${ }^{2} \mathrm{H}$ (deutério, 0,015\%). A razão entre esses dois isótopos é de aproximadamente 0,00015 (IAEA, 2001). A variação da razão entre esses dois isótopos pode chegar a $250 \%$ devido a grande diferença de massa entre eles.

O padrão utilizado para a medida da razão aparente dos isótopos de $\mathrm{H}$ e O foi criada em 1961 por Craig, o Standard Mean Ocean Water (SMOW), calibrado a partir de uma água hipotética baseada na amostra NBS-1. Em 1976, em uma convenção em Viena, a IAEA (IAEA, 2001) apresentou uma amostra de água destilada que seria utilizada como o novo padrão para razão aparente de H e O. Esse novo padrão foi chamado de Vienna Standard Mean Ocean Water (VSMOW) e possui uma composição similar ao SMOW, porém com algumas diferenças em relação aos isótopos de $\mathrm{O}$ e nenhuma diferença significativa com os isótopos de $\mathrm{H}$.

Em 1961, Craig notou uma relação entre $\delta^{18} \mathrm{O}$ e $\delta^{2} \mathrm{H}$ de precipitações no mundo todo, que pode ser definida pela equação abaixo.

$$
\delta^{2} H=8 \delta^{18} O+10 \% \text { o (Craig, 1961) }
$$

Com essa equação, é possível construir uma reta relacionando a composição isotópica das chuvas do mundo todo em seus diferentes climas. Essa relação é conhecida como Global Meteoric Water Line (GMWL). Mas sua maior contribuição é possibilitar o entendimento de que as águas empobrecidas estão associadas a climas frios, e as enriquecidas, às regiões quentes. Essa partição foi logo reconhecida como uma ferramenta para a caracterização de regiões de recarga da água subterrânea.

Mais tarde, Rozanski et al. (1993) chegaram à outra equação para VSMOV, baseada nas precipitações de 219 estações meteorológicas que compõem a rede GMIP (Global Network of Isotopes in Precipitation) da IAEA e WMO (World Meteorological Organization).

$$
\delta^{2} H=8,17( \pm 0,07) \delta^{18} O+11,27( \pm 0,65) \text { (Rosanski et al., 1993) }
$$

Segundo Gat (1971), em clima temperado e úmido, a composição isotópica da água subterrânea condiz com a precipitação na área da recarga. A variação sazonal de toda água da precipitação é fortemente atenuada durante sua infiltração e acumulação no solo 
(HOEFS, 1997). Em geral as águas subterrâneas profundas não demonstram variação sazonal nos valores de $\delta^{2} \mathrm{H}$ e $\delta^{18} \mathrm{O}$ e possuem composição isotópica próxima à média anual de precipitações (HOEFS, 1997), podendo servir como traçador natural de sua proveniência (CLARK e FRITZ, 1997).

A composição isotópica da água é definida por processos meteóricos, além de outros, o que possibilita a correlação de certas características isotópicas da água a uma zona de recarga específica (VIVIANI-LIMA, 2007); assim, a assinatura isotópica pode ser determinada através de amostras de água coletadas nos poços, conhecendo-se características geométricas do aquífero e sua hidráulica (DARLING e BATH, 1988, apud VIVIANI-LIMA, 2007, p.25).

Os isótopos ambientais têm contribuído para as investigações rotineiras, complementando parâmetros geoquímicos e físicos da hidrogeologia. Os isótopos estáveis da composição da água são modificados pelos processos meteóricos, e com isso, a recarga de um determinado local em um ambiente particular terá uma assinatura isotópica característica, e essa assinatura serve como um traçador natural da origem dessa água. Por outro lado, os radioisótopos decaem, fornecendo medidas do tempo de circulação e, portanto, do tempo de renovação. Neste caso, os isótopos fornecem muito mais do que indicações de tempo e origem, mas também sobre qualidade, evolução geoquímica, processo de recarga, interação rocha-água, origem da salinidade e processos de contaminação.

De acordo com Mazor (1991), ao plotar os dados dos isótopos de O e H, se eles ficarem próximos à reta meteórica global (GMWL), é excluída a possibilidade de processos secundários de fracionamento, como evaporação antes da infiltração ou troca dentro do aquífero. Por outro lado, se os dados se posicionarem abaixo da reta, pode-se considerar que ocorreu um fracionamento ou que a água é mais antiga, ou seja, proveniente de precipitações pretéritas.

Wassenaar et al. (2011) foram capazes de entender o comportamento de uma unidade hidrogeológica utilizando isótopos estáveis de $\delta^{2} \mathrm{H}$ e $\delta^{18} \mathrm{O}$ para determinar a importância da chuva, as fontes e fluxos de água de rios e lagos em bacias hidrográficas, além de avaliar as origens de recursos de águas subterrâneas. 
Simões et al. (2006) utilizaram a técnica de isótopos estáveis combinada com as análises químicas para entender a característica do fluxo subterrâneo com recarga lenta, em Caetité, Bahia. Observou-se que, ao confrontar os dados químicos com os isotópicos dos mesmos poços ao longo do fluxo subterrâneo, houve aumento no teor de sais dissolvidos, ao mesmo tempo em que a distribuição dos valores de $\delta^{18} \mathrm{O}$ e $\delta^{2} \mathrm{H}$ das águas subterrâneas permitiram diferenciar entre águas que estiveram mais sujeitas ao processo de evaporação (valores menos negativos) e estão diretamente relacionadas à infiltração reduzida e à recarga mais lenta na zona saturada daquelas que guardam o sinal da precipitação (valores mais negativos), originadas da infiltração direta da mesma, sendo assim resultante de recarga mais rápida no aquífero. Essas águas apresentam se impróprias para consumo, pois, além da contaminação por radionuclídeos, que por si só já impede sua utilização, essa água apresenta um processo de salinização decorrente do clima com altas taxas de evaporação.

Caine e Clark (1999) investigaram a contribuição da recarga de um aquífero carbonático recoberto por camadas arenosas cobertas por atividades agrícolas, em Ontário, Canadá, a fim de obter informações sobre riscos de contaminação por nitrato e pesticidas que se infiltram pela área de cultivo. Nível de água, geoquímica e isótopos ambientais (Deutério e ${ }^{13} \mathrm{C}$ ) foram monitorados em doze poços por um período de 14 meses. As variações sazonais do nível de água sugeriram que a recarga é restrita à primavera e ao outono, quando a transpiração é minimizada e o solo não está congelado, contudo, o monitoramento de deutério mostrou que no verão a precipitação também contribui para a recarga.

Viviani-Lima (2007) utilizou a técnica isotópica para separar as contribuições das fontes naturais (infiltrações diretas e vazamentos do sistema de drenagem pluvial) e das fontes antrópicas (vazamentos dos sistemas de água de abastecimento público e esgoto), encontrando diferença considerável, principalmente, na média ponderada das chuvas maiores de $100 \mathrm{~mm}\left(\delta^{18} \mathrm{O}-7,3 \%\right.$ e $\delta^{2} \mathrm{H}-53,4 \%$ ) quando foram totalmente diferentes da média da água de abastecimento na Vila Eutália $\left(\delta^{18} \mathrm{O}-4,9 \%\right.$ e $\delta^{2} \mathrm{H}-36,8 \%$ ), o que torna o uso da técnica possível. 


\subsection{Uso agrícola da água}

O uso e a ocupação do solo no local de estudo são feitos com produção agrícola de dois tipos de culturas: cana-de-açúcar e eucalipto. A cana-de-açúcar ocupa aproximadamente $90 \%$ da circunferência do lago e o talhão de eucalipto cerca de $10 \%$. Essa ocupação perdurou por todo o tempo da pesquisa com três colheitas de cana-de-açúcar e uma de eucalipto.

\subsubsection{Cultura de cana-de-açúcar}

No cultivo irrigado da cana-de-açúcar, pode-se dividir o ciclo da cana de 12 meses em quatro estágios de desenvolvimento:

- $\quad$ Germinação e emergência = 1 mês;

- $\quad$ Perfilhamento e estabelecimento da cultura = 2 a 3 meses;

- $\quad$ Desenvolvimento da cultura = 6 a 7 meses;

- $\quad$ Maturação $=2$ meses.

No estudo conduzido pela EMBRAPA (2006), a produtividade da cana-de-açúcar responde exponencialmente à abundância de água, sendo os dois primeiros estágios os mais críticos ao déficit hídrico. O terceiro estágio (desenvolvimento) responde à lâmina aplicada, mas o déficit hídrico não causa tantos prejuízos à produtividade quanto aos dois primeiros. O quarto estágio (maturação) responde positivamente ao déficit hídrico. Entretanto, o consumo diário de água é maior no terceiro estágio do que nos dois primeiros. Isso ocorre em função do maior índice de área foliar no terceiro estágio. O teor de açúcar costuma ser afetado adversamente pelo excesso de umidade no estágio de maturação.

O consumo diário de água pela cana-de-açúcar nas principais regiões produtoras do país depende da variedade, do estágio de desenvolvimento da cultura, da demanda evapotranspirométrica em função do mês e da região (variação temporal e espacial), mas em geral tem variado de 2,0 a $6,0 \mathrm{~mm} / \mathrm{dia}$.

Nos experimentos de Souza et al. (1999), à medida que se aumentou a quantidade de água aplicada (irrigação + precipitação), houve incrementos positivos de produtividade até 
atingir um valor máximo. Após esse valor, houve decréscimo de rendimento com o aumento da lâmina total aplicada.

Isso pode ser explicado pelo fato de a água ser um dos fatores limitantes à produção. À medida que se aumenta sua disponibilidade, a cultura pode expressar melhor o seu potencial produtivo até um determinado ponto, após o qual a produtividade passa a decrescer, devido ao excesso de água no solo, à baixa aeração na zona radicular e a lixiviação dos nutrientes.

\subsubsection{Cultura de eucalipto}

Cada tipo de eucalipto responde de uma maneira diferente às condições do déficit hídrico. Suas raízes alcançam níveis variáveis de profundidade, de acordo com a necessidade de água e nutrientes que, em condições inversas, juntamente com impedimentos mecânicos e/ou químicos, compõem os principais limitantes de crescimento das raízes. Com isso, admite-se que a água que a planta retira do solo é função da estrutura do sistema de raízes alojada no solo, sendo as raízes mais finas as mais eficientes, devido à sua maior área de contato.

As árvores crescem bem em regiões que possuem índice de precipitação de 900 a 2000 mm (MORA E GARCIA, 2000), e por outro lado, segundo Davidson (1985), a presença de plantações em locais com índice de precipitação menor que $400 \mathrm{~mm}$ podem acarretar ressecamento do solo, gerando os impactos sobre lençóis freáticos, pequenos cursos de água e bacias hidrográficas.

E. marginata e E. calophylla foram comparadas por Grieve (1956) e suas taxas de transpiração foram $7,2 \mathrm{mg} \cdot \mathrm{g}^{-1} \cdot \mathrm{min}^{-1}$ e $4,2 \mathrm{mg} \cdot \mathrm{g}^{-1} \cdot \mathrm{min}^{-1}$. O E. marginata manteve seus estômatos sempre abertos, enquanto que o E. calophylla, além de apresentar menor taxa de transpiração, fechava seus estômatos durante as partes mais secas do dia, chegando até a valores de transpiração de $0,3 \mathrm{mg} \cdot \mathrm{g}^{-1} \mathrm{~min}^{-1}$. Também foi verificado que o desenvolvimento radicular apresentou desenvolvimento praticamente idêntico, concluindo que o $E$. calophylla é uma espécie que apresenta melhor economia de água durante o verão. O E. camandulesis 
e o E. robusta, provavelmente, pertencem a esse grupo, pois estão restritos a áreas encharcadas e de cursos de água (JACOB, 1955).

Sinclair (1980) comparou as taxas de transpiração de $E$. obliqua, E. leucoxylon e $F$. fasciculosa em Adelaide, Austrália. Ele verificou que o E. obliqua normalmente ocorria em locais com precipitação superior a $875 \mathrm{~mm}$ e que nunca fechava seus estômatos, mesmo quando o potencial de água nas folhas era baixo. O autor argumentou que o E. obliqua não desenvolveu o mecanismo de fechamento dos estômatos quando o potencial de água atingiu valores inferiores ao valor crítico, ou esse valor crítico para essa espécie é menor do que o que normalmente acarreta danos aos tecidos das demais espécies. De fato, foi observada necrose nas folhas do $E$. obliqua, enquanto nas duas outras espécies não foram observados danos visíveis. Martin e Specht (1962) observaram que o E. obliqua esgotava a água disponível no solo mais rapidamente que as outras duas espécies e tinha, dessa forma, que suportar um período de seca maior durante o ano. Essas espécies de eucalipto de alto consumo de água devem, para sobreviver, apresentar um sistema radicular profundo, o qual permite acesso ao lençol freático, ou restringir-se a micro habitat específico, onde as condições de disponibilidade de água no solo sejam favoráveis o ano todo. Esse grupo de eucalipto é pequeno, limitando-se a algumas poucas espécies, principalmente as citadas. A grande maioria desenvolveu mecanismos fisiológicos de adaptação a condições de déficit hídrico, ou seja, mecanismos de restrição do consumo de água nos períodos do ano quando a disponibilidade de água no solo é menor. Entre esses mecanismos estão (JACOB, 1955; PRYOR, 1976; FLORENCE, 1981): a) desenvolvimento de tecido foliar endurecido; b) alinhamento vertical das folhas; c) lignotuber; d) melhor eficiência no fechamento dos estômatos em resposta ao estresse hídrico; e) menor taxa de transpiração em condições de alto teor de umidade no solo; f) eficiência fotossintética em condições de disponibilidade de água; g) alto valor para a relação raiz/copa.

Poore e Fries (1985) afirmam que, quanto mais rápido o crescimento de uma árvore, maior seu consumo de água. Estima-se que a faixa de evapotranspiração de uma plantação de eucalipto seja equivalente a precipitações pluviométricas ao redor de 800 a $1.200 \mathrm{~mm} / \mathrm{ano}$ (FOELKEL, 2005). 
Lima (1990) apresentou resultados experimentais semelhantes a esse de perda de água do solo em plantações de E. globulus ao redor de 750 mm/ano - estimados pelo método de avaliação do balanço hídrico do solo.

\subsection{Geofísica}

Em estudos hidrogeológicos, as técnicas geofísicas têm excelente aplicabilidade quando necessário determinar profundidades, flutuações temporais e espaciais dos aquíferos, direções preferenciais de fluxos subterrâneos e também detecção e dimensionamento espacial de plumas de contaminação.

Dentre os métodos geofísicos de exploração, os assim denominados métodos elétricos estão cada vez mais sendo utilizados em estudos hidrogeológicos uma vez que apresentam boa resolução e custo relativamente barato. Outro fator importante quando se utiliza destes métodos, é em relação ao tempo gasto para obter os dados necessários sendo, na maioria das vezes, mais rápido que os métodos convencionais de investigação, denominados métodos diretos (SARAIVA, 2010).

Segundo Gallas (2000), o aumento do teor de umidade e da quantidade de sais dissolvidos causa uma diminuição dos valores de resistividade no solo. Essa condição é que permite a imensa possibilidade de aplicação do método de eletrorresistividade em estudos ambientais e hidrogeológicos, onde a presença de água na zona saturada pode ser detectada pelo método, bem como a variação da umidade na zona não saturada.

O método de eletrorresistividade, através da aplicação de sondagens elétricas verticais (prospecção vertical) e de caminhamentos elétricos (prospecção horizontal), é capaz de fornecer informações básicas sobre as separações de formações arenosas de formações argilosas, variação de espessura, descontinuidades laterais, profundidade e feições do embasamento cristalino, variações de transmissividade e da qualidade da água, entre outras (FEITOSA et al., 2008).

O método da eletrorresistividade, utilizando-se da técnica de Caminhamento Elétrico (CE), investiga as mudanças que ocorrem nos valores de resistividade do solo a partir das variações de umidade do solo. 
Outra técnica utilizada, Sondagem Elétrica Vertical (SEV), é fundamental para o estudo de estratos geoelétricos, especialmente, quando necessário distinguir diferentes litologias e detectar a profundidade do nível freático.

Por fim, o método do Potencial Espontâneo (SP) tem sua principal aplicação no estudo do comportamento do fluxo de águas em subsuperfície. As anomalias de SP são geradas pelo fluxo de fluidos, de calor ou de íons no subsolo. Tem mostrado resultados satisfatórios quando necessário localizar e delimitar esses fluxos e suas fontes associadas (GALLAS, 2000).

Em Oliva (2006), foi aplicado o método geoelétrico da eletrorresistividade, utilizando as técnicas de sondagem elétrica vertical e imageamento elétrico $2 \mathrm{D}$ e $3 \mathrm{D}$, em escala de município e de detalhe (Campus Bela Vista da Unesp de Rio Claro), reconhecendo litofáceis que identificaram e delimitaram o aquífero, de maneira a fazer uma subdivisão das unidades geoelétricas. Com isso, foram elaborados mapas de eletrorresistividade em escala de município e de detalhe, com o intuito de verificar a distribuição especial das eletrofáceis presentes no Aquífero Rio Claro, na zona saturada. Os dados geofísicos revelam que as eletrofáceis arenosas da Formação Rio Claro abrangem grande parte da área, as siltoarenosas e as silto-argilosas estão distribuídas aleatoriamente, e que existe ampla variação na espessura da Formação Rio Claro, caracterizando um estrato bastante irregular. 


\section{4. Área de Estudo}

\subsection{Localização}

O município de Rio Claro localiza-se no centro do Estado de São Paulo, na Depressão Periférica Paulista, unidade geomorfológica representada por uma área rebaixada, com altitudes de 500 a $700 \mathrm{~m}$. É circundado, em um raio de $30 \mathrm{~km}$, pelos municípios vizinhos Corumbataí e Leme, ao norte; Piracicaba e Iracemápolis, ao sul; Araras e Santa Gertrudes, a leste; e Ipeúna e Itirapina, a oeste (Figura 2).

A região estudada está situada a oeste da área urbana de Rio Claro, dentro da zona rural, caracterizada pela presença de uma sequência de três lagoas no topo de divisores de água. É igualmente característica dessa região a presença de agricultura, principalmente cana-de-açúcar e eucalipto.

A principal via de acesso é pela Rodovia Washington Luís, saída 174, no Município de Rio Claro. Seguir pela Estrada Velha para Ipeúna, sentido Ipeúna e após aproximadamente 4,5 km por estrada de terra, pegar entrada para engarrafadora de Água Embaúba.

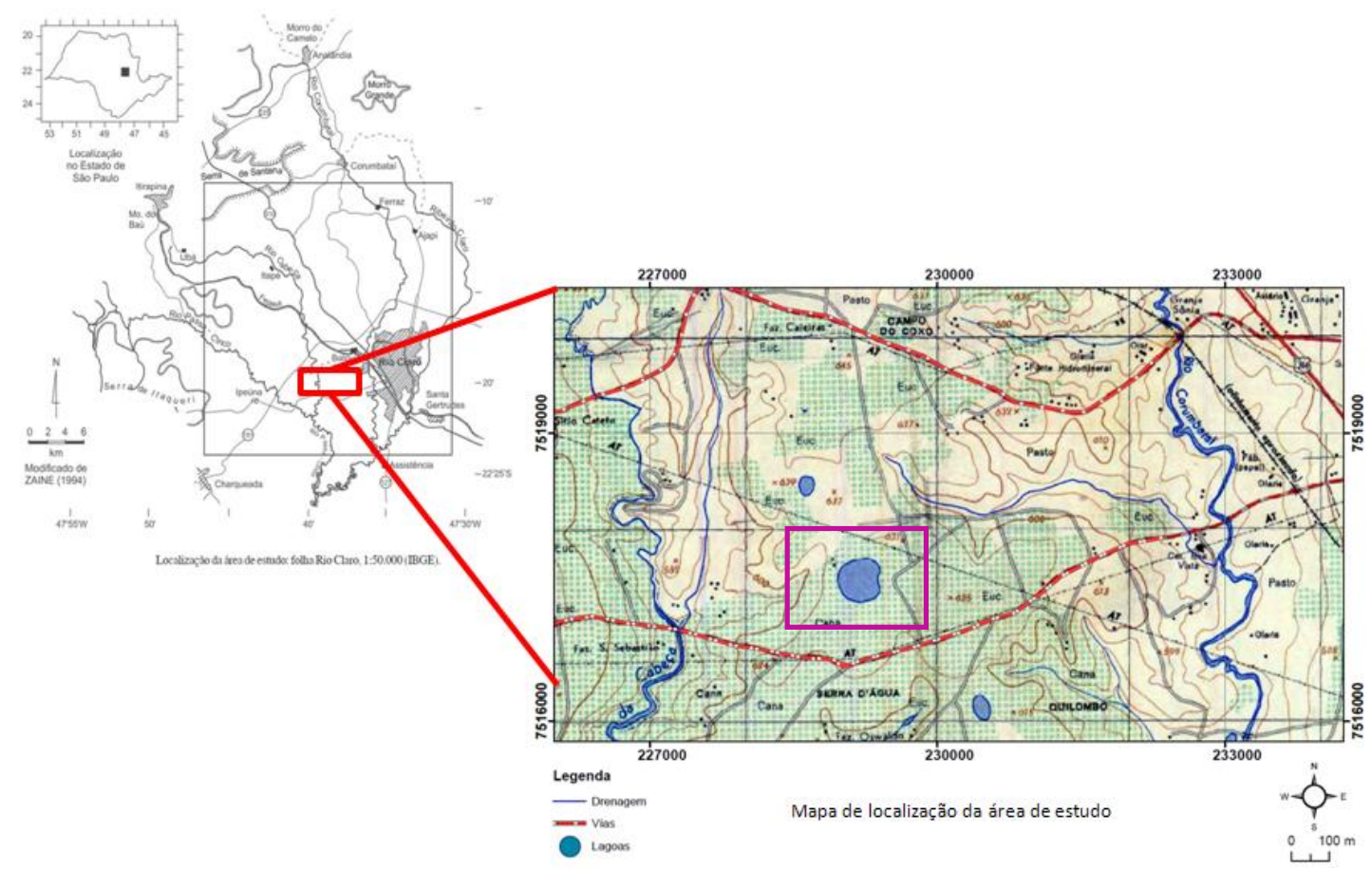

Figura 4. Localização da área de estudo (fonte: Folha Rio Claro, 1:50.000 (IBGE) Modificado de Zaine (1994), mapa topográfico da área, 1:50.000 (IBGE, 1969)) 


\subsection{Aspectos fisiográficos}

Segundo a classificação de Koppen, o clima da área é do tipo CWA, ou seja, clima tropical chuvoso, com chuvas no verão e inverno seco, com temperatura média mensal em quase todos os meses do ano superior a $18^{\circ} \mathrm{C}$. Com seu mês mais quente com temperatura acima de $22^{\circ} \mathrm{C}$, enquanto a precipitação do mês mais chuvoso chega a ser dez vezes maior que o mês mais seco.

Troppmair (1992) observou que a região de Rio Claro pode ser considerada como tropical com duas estações definidas, pois de abril a setembro é um período seco com chuvas entre 180 a $200 \mathrm{~mm}$ que ocorrem em 15 a 20 dias e temperatura média de $17^{\circ} \mathrm{C}$, e de outubro a março compreende o período chuvoso, com 55 a 60 dias de chuvas, com um total de $1200 \mathrm{~mm}$.

Santos (1986) observou a existência de ciclos em termos de anos secos e chuvosos no município de Rio Claro. O ano mais seco foi o de 1921 com $655 \mathrm{~mm}$ de chuva e o mais chuvoso alcançou $2144 \mathrm{~mm}$ em 1976.

\subsection{Geologia}

Regionalmente, a área está inserida na porção nordeste da Bacia Intracratônica do Paraná, constituída por uma sucessão sedimentar-vulcânica com idades neo-ordovicianas a neocretáceas (MILANI, 2004). A área de estudo, particularmente, está localizada sobre os sedimentos correlacionáveis à Formação Rio Claro.

A Formação Rio Claro é caracterizada por depósitos cenozoicos, que constituem extensas áreas de ocorrência no Estado de São Paulo (BJORNBERG e LANDIN, 1966). Corresponde a níveis escalonados na paisagem, vinculados a diferentes fases de aplainamento do terreno, formando extensos tabuleiros. Apresenta espessuras não ultrapassando $30 \mathrm{~m}$ (FREITAS et al., 1979), sendo constituída por sucessões de estratos arenosos com intercalações subordinadas de leitos argilosos em sua base e por sedimentos argilosos, com brechas intraformacionais e lentes arenosas subordinadas em seu topo 
(FÚLFARO e SUGUIO, 1968). Esses autores interpretaram que a origem dessa formação está relacionada ao longo de um paleocanal fluvial, correspondente a um pretérito rio Corumbataí, barrado a jusante em função da reativação das falhas na área da estrutura de Pitanga. Dados de sondagens realizadas por Zaine (1994) em indústrias do Distrito Industrial para o monitoramento do lençol freático mostraram espessuras da ordem de 25 a $30 \mathrm{~m}$, com o nível de água situado sempre na base da Formação Rio Claro, no contato com a Formação Corumbataí. Em poços situados próximos entre si, em um raio de 100 m, pode-se notar algumas irregularidades do contato basal da Formação Rio Claro, assim como diferentes vazões para poços vizinhos. Cottas (1983), através de investigações geofísicas, registrou no Distrito Industrial, espessura de $39 \mathrm{~m}$ que denominou coberturas inconsolidadas, que corresponderiam à Formação Rio Claro.

Björnberg e Landim (1966) identificaram três níveis topográficos principais capeados por sedimentos neocenozóicos na área da Depressão Periférica e Cuestas Basálticas próximas a Rio Claro:

- entre 900 e 1000 metros, está situado no município de São Carlos;

- entre 800 e 900 metros, corresponde à Serra de Santana e à área da cidade de Itirapina;

- entre 600 e 800 metros, está situado na cidade de Rio Claro.

A Formação Rio Claro sobrepõe-se aos depósitos mais antigos da Bacia do Paraná, sendo eles as formações Pirambóia e Corumbataí. A Formação Pirambóia é caracterizada por uma sucessão de camadas arenosas, de coloração avermelhada que, em superfície, apresenta espessuras maiores do que 270 metros. Em subsuperfície, pode atingir até 350 metros (IPT, 1981). Ainda segundo IPT (1981), os arenitos são geralmente de granulação média à fina, possuindo uma fração argilosa maior na parte inferior do que na superior da formação, onde localmente ocorrem arenitos grossos conglomeráticos. As estruturas sedimentares predominantes nesses depósitos são estratificações plano-paralelas e cruzadas tangenciais de médio a grande porte.

O limite basal dessa formação se dá de maneira discordante com a Formação Corumbataí, Grupo Passa Dois (IPT, 1981), sendo esta de coloração arroxeada, de origem marinha e predominantemente constituída por sedimentos finos, como siltitos e argilitos. 
Quando esse material encontra-se em superfície, há intenso fraturamento e "empastilhamento" do mesmo.

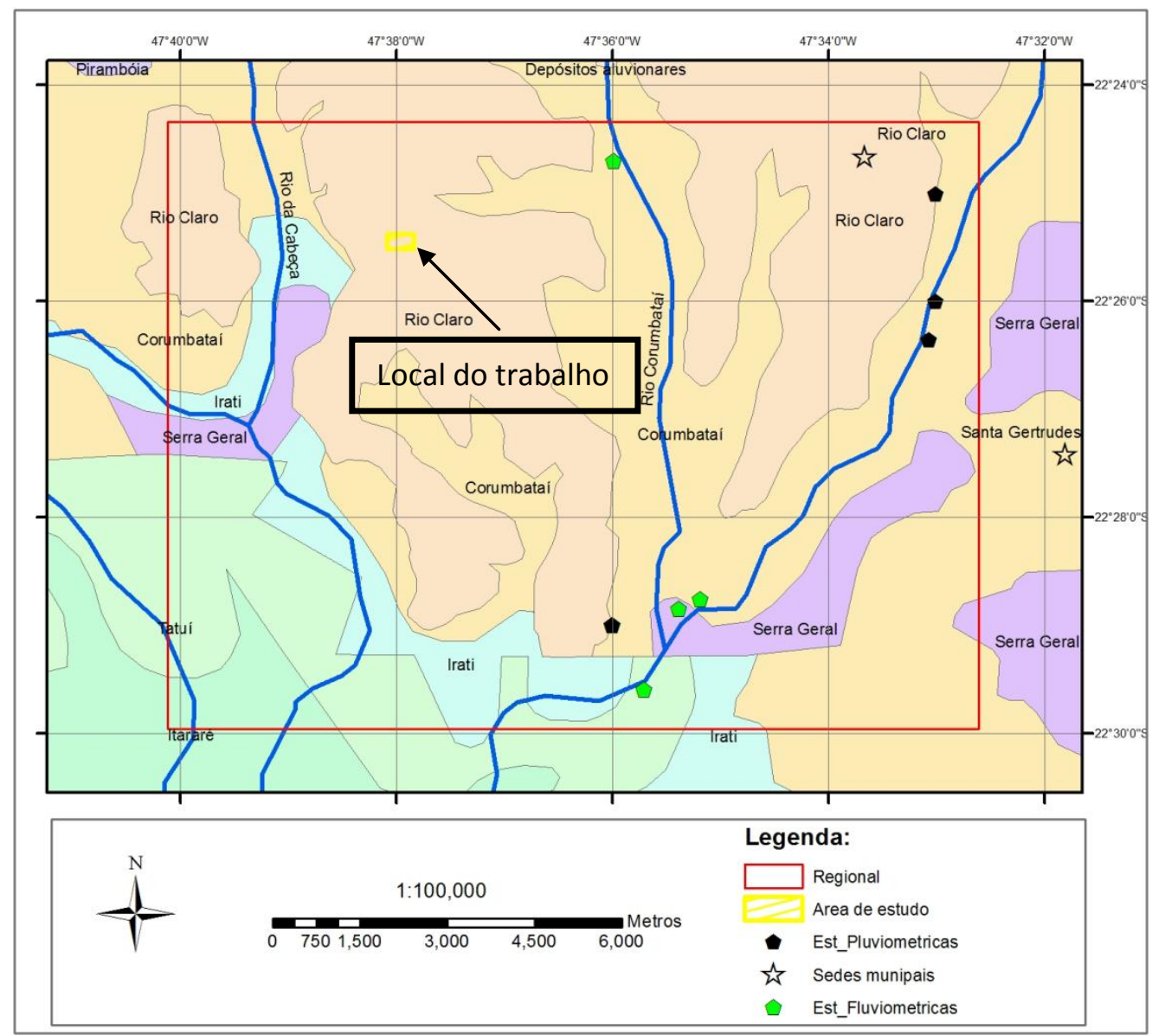

Figura 5. Geologia e hidrologia da área de estudo.

Oliva et al. (2005) observaram que o principal constituinte detrítico do arcabouço dos arenitos da Formação Rio Claro é o quartzo. Os feldspatos que não apareceram nas amostras descritas provavelmente sofreram diagênese, lixiviação e transformação para argilominerais, juntando-se à matriz argilosa e compondo uma pseudomatriz. A matriz é constituída por cutículas de argila, cuja composição é caulinítica, envolvendo os cristais de quartzo e preenchendo os poros, podendo conter fragmentos líticos, principalmente os sedimentares. A autora ainda afirma que os arenitos dessa formação possuem granulometria que varia de areia fina à média, sendo que alguns apresentam teor de argila e outros são conglomeráticos. Seus grãos são subarredondados a arredondados. Foram classificados como quartzo-arenito por Folk (1968), porém com grande quantidade de matriz, são mais 
bem classificados como quartzo-arenito imaturo. Quanto ao arcabouço geológico, no município de Rio Claro predominam os arenitos. Como consequência, os solos de textura arenosa propiciam a rápida infiltração das águas de chuva. Ao percolar os diferentes horizontes dos solos, a água promove a lixiviação, tornando-os pobres e ácidos. (TROPPMAIR, 1992).

O mapeamento pedológico realizado por Prado et al. (1981) na quadrícula de São Carlos mostra que ocorrem basicamente três tipos de solos no município de Rio Claro:

1. Podzóico vermelho-amarelo de textura média/argilosa, presente nos baixos topográficos, ou seja, nos vales do Rio Corumbataí e Ribeirão Claro, formado a partir de sedimentos finos dos grupos Passa Dois e Tubarão, sendo que no município de Rio Claro, as rochas originais são principalmente os siltitos da Formação Corumbataí (COTTAS, 1983);

2. Latossolo vermelho-amarelo que atinge profundidades máximas de 10 a $12 \mathrm{~m}$, correspondendo ao solo de alteração da Formação Rio Claro;

3. Latossolo roxo de textura argilosa a muito argilosa.

\subsection{Hidrogeologia e Hidrografia}

De acordo com o DAEE (1981), o aquífero na área de estudo é o Aquífero Rio Claro, composto pelos sedimentos correlacionáveis à Formação Rio Claro. Ele é de natureza livre e pouco profundo, apresentando vazões entre 17 e $25 \mathrm{~m}^{3} / \mathrm{h}$, constituído por materiais pouco argilosos. Segundo Oliva (2006), o nível de água é raso, havendo, no entanto, ampla variação das profundidades, prevalecendo as inferiores a $18 \mathrm{~m}$. Por se tratar de um aquífero livre, composto por sedimentos de alta e média permeabilidade, os níveis de água acompanham, de modo geral, a topografia. As áreas de recarga compreendem toda a área de afloramento e as de descarga, os rios e drenagens superficiais.

Adicionalmente, há o aquífero da Formação Pirambóia, que faz parte do Sistema Aquífero Guarani e se apresenta como um excelente aquífero. Em sua área de exposição, trata-se de um aquífero livre e de rápida circulação das águas. Já o Corumbataí, forma regionalmente um aquitarde, devido à baixa permeabilidade de suas rochas. 
O município de Rio Claro está inserido na bacia hidrográfica do Rio Corumbataí. A bacia ocupa uma área de 171.050 ha e abrange parte dos municípios de Analândia, Itirapina, Corumbataí, Santa Gertrudes, Ipeúna, Charqueada, além de Piracicaba, onde o Rio Corumbataí deságua no Rio Piracicaba.

O Rio Corumbataí possui uma extensão de aproximadamente 120 km. Nasce na Serra de Santana a 800 m de altitude e descreve muitas curvas e meandros ao cortar o município de Rio Claro, devido ao seu pequeno declive, em média de 2 metros por quilômetro (OLIVA, 2002).

Segundo Penteado (1976), o Rio Corumbataí tem um condicionante tectônico para sua orientação, ou seja, falhamentos pós-cretáceos que afetaram a região. Isso porque o traçado do Rio Corumbataí e de seus afluentes maiores, especialmente o Rio Passa Cinco, possuem direções nitidamente orientadas e se correlacionam entre si com as linhas de relevo.

Topograficamente, a unidade posiciona-se entre as cotas de 650 a $670 \mathrm{~m}$, nos arredores de Ipeúna e de Ajapi, até as cotas mais baixas, por volta de 580 metros, próxima à confluência do Rio Corumbataí e Ribeirão Claro.

A Formação Rio Claro tem ocorrência não uniforme e aparece dispersa em forma de manchas pelos topos dos divisores de águas, sendo a maior delas sob a cidade de Rio Claro e o Distrito de Ajapi, divisor Corumbataí-Cabeça (Mapa Geológico - Anexo I).

\subsection{Lagoas}

A presença de lagoas espalhadas pela composição da paisagem na Formação Rio Claro é muito particular na região. Essa morfologia é composta por solo predominantemente arenoso, espesso, em um relevo de colinas amplas a tabuliformes, com baixo número de drenagens.

As lagoas formam-se em depressões suaves, fechadas ou ligadas pela superfície a alguma rede de drenagem, por vezes constituindo a origem de um curso de água. Apresentam formatos circulares a ovalados, com diâmetros de 100 a 500 m, são 
intermitentes com nível de água oscilando nas estações secas e chuvosas, chegando a secar em períodos de estiagem mais prolongados.

Björnberg et al. (1964 a, b, apud ZAINE, 1994, p.33) associaram a origem dessas lagoas àquelas remanescentes da sedimentação da Formação Rio Claro, representando meandros abandonados, integrantes do sistema fluvial responsável pela gênese da unidade. Os autores também basearam-se no fato de que plantas aquáticas das lagoas atuais são semelhantes aos vegetais fósseis descritos na Formação Rio Claro.

Françoso et al. (1974, apud ZAINE, 1994, p.33) relacionaram sua gênese ao rebaixamento do nível de base local ao estudar depressões doliniformes (com lagoas) no platô de Itapetininga, decorrente do entalhamento da rede de drenagem atual, associado à solubilização e à lixiviação de sedimentos carbonáticos (Formação Irati) ou de rochas intrusivas básicas. Também citaram que as lagoas representam o primeiro indício da instalação da rede de drenagem atual e que o alinhamento das mesmas seguiria direções estruturais preferenciais NE-SO e secundárias (ortogonais) NO-SE.

Penteado-Orellana (1981, apud ZAINE, 1994, p.33) explicou a existência de lagoas na região de Rio Claro como "paleocabeceiras" de drenagem, colocadas em uma posição topográfica mais elevada que as atuais, representando, então, épocas mais úmidas de um passado não muito distante.

Zaine (1994) adotou a evolução morfogenética para explicar a formação dessas lagoas, a qual aliou a existência de uma superfície aplainada (superfície neogênica de De Martone), de um substrato de alta porosidade, isto é, com grande infiltração e circulação de águas atmosféricas no solo e subsolo, com as condicionantes estruturais, que determinaram áreas de maior infiltração e percolação em subsuperfície, originando essas depressões fechadas. A tectônica teria definido as direções preferenciais, que orientaram e alinharam algumas lagoas entre si e com outros elementos de drenagem e relevo. Em seguida, teria ocorrido a sedimentação e colmatação do fundo das lagoas, levando o sistema ao equilíbrio. No caso da ligação superficial das lagoas com a rede de drenagem, essas passariam a constituir lagoas de cabeceiras.

Vários autores discutiram a origem do ambiente deposicional da Formação Rio Claro sendo propostas duas hipóteses. Björnberg e Landim (1966) admitiram a elaboração de 
sedimentos a partir de depósitos torrenciais e desorganizados, em condições semiáridas, a qual é também compartilhada por Penteado (1976).

Fúlfaro e Suguio (1968), por sua vez, sustentaram que a ocorrência de um represamento devido a interferências de ordens tectônicas seria responsável pela acumulação de sedimentos em um ambiente fluvial, constituindo-se um paleocanal tectonicamente condicionado entre a escarpa da Serra Geral e um falhamento que soergueu a sequência da margem esquerda do Ribeirão Claro.

Zaine (1994) identificou fáceis conglomeráticas com estratificação cruzada e acumulação de seixos na base e granodecrescência ascendente que ocorrem, preferencialmente, na porção basal da unidade. Segundo a autora, isso representa os leques aluviais, ou seja, correspondem a condições de maior energia de transporte. Outra associação discreta é dada pela alternância de camadas arenosas e argilosas, representativa de certa organização do sistema fluvial, com canais rasos e espraiados, sem poder de aprofundamento de seu leito junto às planícies de inundação. Dentro do contexto deposicional em um sistema fluvial, os bancos argilosos mais expressivos poderiam representar lagoas, de ocorrência restrita em área, dentro da planície de inundação.

Os sedimentos têm origem a partir das formações Botucatu e Pirambóia, considerando sua proximidade e semelhanças granulométricas e texturais. Também são encontrados clastos da base e camadas pelíticas oriundas da Formação Corumbataí, bem como rochas vulcânicas e minerais pesados como magnetita, turmalina e goethita nos arenitos (ZAINE, 1994).

Oliva (2006) verificou que os altos potenciométricos na porção do município de Rio Claro possuem fluxo centrífugo e estão basicamente distribuídos na porção norte da área, coincidentes com as lagoas da Fazenda São José e a Lagoa do Cacareco. Essas lagoas representam aquíferos suspensos, com profundidades que vão de 1 a $2 \mathrm{~m}$, onde o fluxo das águas superficiais infiltradas é bloqueado por níveis de materiais com baixa permeabilidade, tais como camadas argilosas, comuns em ambiente fluvial. Somente o Lago Azul, localizado a sudoeste da Lagoa do Cacareco, faz parte do aquífero livre Rio Claro. Os altos potenciométricos funcionam como divisores de águas e estão aproximadamente paralelos aos limites da Formação Rio Claro, assim como a superfície potenciométrica, que segue a 
orientação preferencial do Rio Corumbataí, a oeste da área, e do Ribeirão Claro, a leste. Os baixos potenciométricos estão distribuídos na porção sul da área, onde a Formação Rio Claro apresenta pequenas espessuras e encontra-se próxima ao contato com unidades subjacentes.

\subsection{Aspectos da hidroquímica da Formação Rio Claro}

Oliva (2006) fez uma síntese das características das águas subterrâneas do Aquífero na porção do Município de Rio Claro. As amostras de poços e nascentes apresentaram pH na faixa de 5,16 a 7,70, sendo que, as com pH na faixa de 6 a 7 refletem o caráter neutro a levemente ácido das águas, que foram classificadas como bicarbonatadas cálcicas magnesianas e bicarbonatadas sódicas (OLIVA, 2002), corroboradas por Bonotto e Mancini (1992), que também as classificaram da mesma maneira.

Segundo Oliva (2002), na zona urbana, o Aquífero Rio Claro mostra sinais de contaminação por esgoto doméstico (altos teores de nitrato e cloreto) e contaminação industrial (presença de sulfato). Em suas medições em águas superficiais, o pH variou de 5 a 9,5, com média de 6,3 , porém as águas de chuva possuem um $\mathrm{pH}$ moderadamente ácido $(5,7)$, devido à incorporação de dióxido de carbono da atmosfera (STRADIOTO, 2004).

Oliva (2006) registrou que as águas de chuvas, no Município de Rio Claro, são classificadas predominantemente como bicarbonatadas cálcicas magnesianas, sendo que algumas delas chegaram a cloretadas sódicas e bicarbonatadas sódicas. As amostras de águas superficiais, no Município de Rio Claro, apresentam as mesmas classificações das amostras de águas de chuva (STRADIOTO, 2004).

Com base nos trabalhos de Oliva (2002) e Stradioto (2004), Oliva (2006) concluiu que os corpos de água (nascentes e lagoas) e o Aquífero Rio Claro (água subterrânea) são abastecidos por águas pluviais, o que é condizente com um modelo geoquímico de intensa lixiviação associado à alta pluviosidade. 


\section{Materiais e Métodos}

\subsection{Perfuração de poços de monitoramento}

Foram construídos, ao todo, 35 poços de monitoramento seguindo a Norma ABNT NBR 15495 (2007), tendo início em novembro de 2011 até outubro de 2014. As perfurações foram realizadas por empresa terceirizada, utilizando trado manual e trado mecanizado para execução das sondagens com diâmetros de 4 polegadas e instalação de tubos geomecânicos de 2 polegadas de diâmetro. Após a colocação dos tubos, foi utilizado um pré-filtro suficiente para cobrir o filtro, selado com bentonita e cimentado. Após a construção, o poço foi limpo e desenvolvido com auxílio de bailer.

As profundidades foram definidas com base nas sondagens de amostras de solo durante a própria perfuração do poço até uma camada espessa de argila, que em geral foi encontrada em profundidades entre 4 a $16 \mathrm{~m}$, da parte mais baixa para a parte topograficamente mais alta. Dessa maneira, optou-se por poços próximos ao nível de água com profundidades entre 0,5 a $19 \mathrm{~m}$.
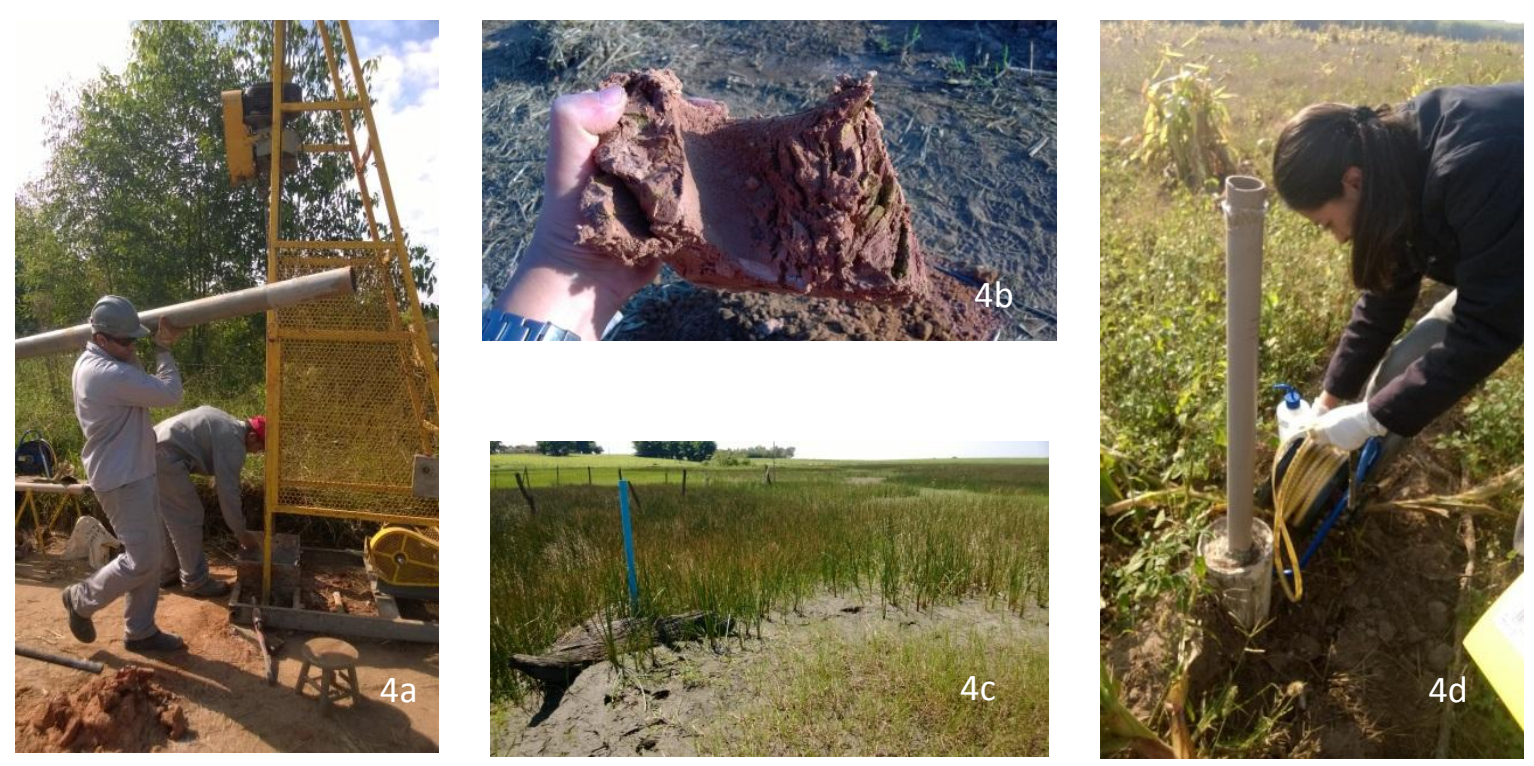

Figura 6a. Sondagem por trado mecanizado; $4 \mathbf{b}$ amostra do solo; 4c lago e 4d poço 20. 


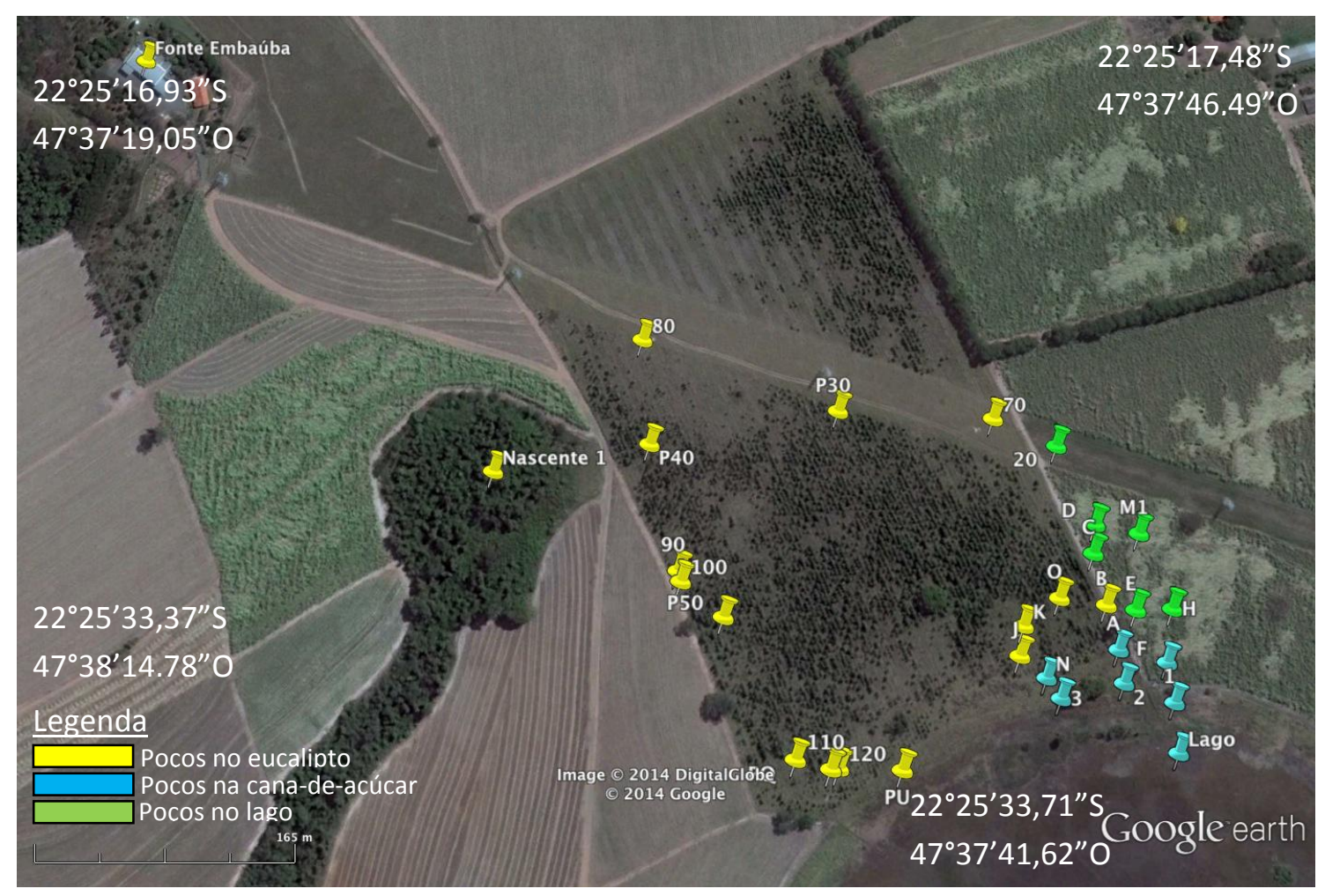

Figura 7. Mapa de localização dos poços de monitoramentos

Os poços de monitoramento foram distribuídos de acordo com a ocupação do terreno, sendo que os poços marcados em amarelo estão na área de plantação de eucalipto, os em verde na área de plantação de cana-de-açúcar e em azul na área da lagoa. Também foram considerados a fonte de água Embaúba e a Nascente 1. As coordenadas e outras características estão descritas no Anexo III.

\subsection{Slug tests}

A condutividade hidráulica foi determinada pela lei de Darcy através da aplicação de Slug Test. Esse teste consiste na inserção de um tarugo (feitos de tubos de PVC fechados nas pontas e preenchidos com material mais denso) nos poços de monitoramento. $\mathrm{O}$ aumento do nível de água causado pela inserção do tarugo e o subsequente rebaixamento até o nível original foram monitorados por um transdutor de pressão em intervalos de um segundo, até atingir o nível original. Por fim, para se obter o valor da condutividade hidráulica, foi adotado 
o cálculo pelo Método Hvorslev (1951), com auxílio do software Aquifer Test para Windows, Waterloo Hydrogeologic, Inc. versão 2010.1, que é determinado pela fórmula abaixo:

$$
K=\frac{r^{2} \ln \left(\frac{L_{c}}{R}\right)}{2 L_{c} T_{0}}
$$

Onde:

K - condutividade hidráulica $(\mathrm{m} / \mathrm{s})$;

$r$ - raio do revestimento $(m)$;

$R$ - raio do poço $(m)$;

Le - comprimento do filtro $(m)$;

$\mathrm{T}_{0}$ - tempo que leva para o nível da água cair a $37 \%$ da posição inicial (s)

Oliva (2002) fez um comparativo entre a condutividades hidráulicas da zona saturada da Formação Rio Claro utilizando dois diferentes métodos: Hvorslev e Bouwer-Rice, chegando a valores da ordem de magnitude entre $10^{-2}$ e $10^{-4} \mathrm{~cm} / \mathrm{s}$, dependendo da variação litológica da Formação. Oliva et al. (2005) calcularam a condutividade hidráulica para zona não saturada, chegando a valores na faixa de $10^{-5}$ e $10^{-4} \mathrm{~m} / \mathrm{s}$. Zanetti (2012) aplicou métodos geofísicos combinados com testes de bombeamento e chegou a valores na faixa de $1,53.10^{-5}$ $\mathrm{m} / \mathrm{s}$ e $8,04.10^{-4} \mathrm{~m} / \mathrm{s}$, cálculados em função das resistividades obtidas pelas SEVs, considerando toda a espessura da zona não saturada.

O resultado obtido para condutividade hidráulica neste trabalho foi de $1,96.10^{-5} \mathrm{~m} / \mathrm{s}$, próximo ao limite obtido por Oliva (2002), então será adotado o valor de $1,96.10^{-5} \mathrm{~m} / \mathrm{s}$ nesta pesquisa.

\subsection{Monitoramento do nível de água}

Após conclusão das construções dos poços, eles foram desenvolvidos e o monitoramento dos níveis de água foi feito com auxílio de medidores de níveis manuais da marca Hidrosuprimentos. O monitoramento iniciou-se no mês de novembro de 2011 e estendeu-se até outubro de 2014 , e foi realizado em todos os poços instalados, sendo que 
suas referências foram fixadas na boca do tubo, depois foi descontada a medida da parte externa desse mesmo tubo para obtenção do valor do nível de água.

Foi instalado um datalogger da marca HOBBO a fim de medir continuamente a condutividade elétrica, temperatura e pressão em um poço dentro da área de eucalipto (poço G) e outro na área de cana-de-açúcar (poço H), porém com a escassez de chuva do período, esses poços secaram. Com isso, foi construído outro para isso, que também veio a secar.

\subsection{Mapas potenciométricos}

Para construção de mapas potenciométricos, um levantamento planoaltimétrico foi feito com uso de um teodolito a laser pela empresa Montana Soluções Ambientais. Dos valores das cotas altimétricas, são descontados o nível de água corrigido para construção das linhas equipotenciais que fornecem a direção de fluxo local da água subterrânea quando desenhadas em mapa.

\subsection{Coleta de água e análises físico-químicas e isotópicas e análises químicas}

A qualidade da amostragem da água subterrânea é fundamental para que os dados químicos sejam representativos do aquífero, propiciando uma interpretação consistente. Dessa forma, foi utilizada a metodologia de baixa vazão (low flow), de acordo com os procedimentos estabelecidos pela USEPA (1995), e a amostragem foi realizada segundo o Procedimento para Amostragem de Água Subterrânea IV.3 da CETESB.

Nesse método, realiza-se a coleta por meio de purga controlada do poço, utilizandose de baixas vazões de bombeamento, ligeiramente inferiores à capacidade de recuperação do poço, causando o mínimo rebaixamento possível. Durante esse procedimento, parâmetros físico-químicos foram monitorados com auxílio de uma célula de fluxo, com a finalidade de definir o momento da coleta da água (água representativa da formação). Configura-se o momento certo quando ocorre a estabilidade hidrogeoquímica, avaliada com a determinação sistemática dos parâmetros abaixo: 
Tabela 2. Critérios de estabilização (EPA, 2000)

\begin{tabular}{|l|l|}
\hline Parâmetro & Variação permitida \\
\hline $\mathrm{pH}$ & 0,1 unidades \\
\hline Condutividade elétrica & $3 \%$ \\
\hline Potencial oxi-redução (Eh) & 10 milivolts \\
\hline Turbidez & $10 \%$ (quando a turbidez for maior que 10 UTN) \\
\hline Oxigênio dissolvido & $0,3 \mathrm{mg} / \mathrm{L}$ \\
\hline
\end{tabular}

Os equipamentos utilizados foram célula de fluxo acoplada em medidor multiparamétrico, modelo Professional Plus, da marca YSI, obtendo-se, dessa maneira, os parâmetros: $\mathrm{pH}$, temperatura, condutividade elétrica, oxigênio dissolvido e potencial de óxido-redução, e uma bomba peristáltica, marca Geopump II.

Após a estabilização dos parâmetros mencionados, a água de amostragem foi utilizada para lavar pelo menos três vezes cada recipiente utilizado (GIBS e WILDE, 1999, apud MARTINS, 2008, p.34).

Para as análises de íons maiores, utilizou-se recipiente de polietileno. Separadamente, foram coletados amostras em frascos de $100 \mathrm{~mL}$ para ânions e para cátions. A amostragem de ânions não requer pré-tratamento, então foi recolhida logo após a estabilidade físico-química. Por outro lado, os cátions requerem filtração $0,45 \mu \mathrm{m}$ e acidificação com algumas gotas de ácido nítrico concentrado. Terminada a coleta, as amostras foram acondicionadas em uma caixa térmica com gelo e encaminhadas para o Laboratório de Hidrogeoquímica do Centro de Pesquisas de Águas Subterrâneas do Instituto de Geociências da USP (CEPAS-IGc-USP). Os ânions foram analisados pelo cromatógrafo de íons DIONEX ICS-90 e os cátions pelo Espectrômetro de Absorção Atômica GBC 932plus.

A alcalinidade, assim como o oxigênio dissolvido, foram medidos em campo, pois, o gás carbônico é muito sensível à mudança de temperatura e pressão. Nesse sentido, foi utilizado um titulador automático da marca $\mathrm{HACH}$, modelo AL-DT, com ácido sulfúrico de concentrações $0,01 \mathrm{M}$ e $0,1 \mathrm{M}$, ambos padronizados. 
Para as análises isotópicas, as amostras foram coletadas em frasco âmbar de $20 \mathrm{ml}$, preenchidos totalmente, a fim de se evitar o fracionamento. Essas amostras foram encaminhadas e analisadas no Laboratório de isótopos da Universidade de Tsukuba.

Após as análises químicas, seguiu-se com os testes de confiança (apêndice V) dos dados através de razões iônicas e balanço iônico, segundo as equações abaixo, em meq/L:

$$
\begin{gathered}
\mathrm{R}=\left[\mathrm{K}^{+}\right] /\left(\left[\mathrm{Na}^{+}\right]+\left[\mathrm{K}^{+}\right]\right) \\
\mathrm{R}=\left[\mathrm{Mg}^{2+}\right] /\left(\left[\mathrm{Ca}^{2+}\right]+\left[\mathrm{Mg}^{2+}\right]\right) \\
\mathrm{R}=\left[\mathrm{Ca}^{2+}\right] /\left(\left[\mathrm{Ca}^{2+}\right]+\left[\mathrm{SO}_{4}{ }^{2-}\right]\right) \\
\mathrm{R}=\left[\mathrm{Na}^{+}\right] /\left(\left[\mathrm{Na}^{+}\right]+\left[\mathrm{Cl}^{-}\right]\right) \\
\text {Erro\% }=\left(\mathrm{r} \sum \text { cátions }-r \text { Zânions }\right) /\left(\mathrm{r} \sum \text { cátions }+r \text { ânions }\right) \times 100
\end{gathered}
$$

Para efeito de conferência, os percentuais de erros calculados no balanço iônico podem ser comparados com as condutividades elétricas. De modo geral, um valor alto de condutividade elétrica é inversamente proporcional à porcentagem do erro calculado (Tabela 6):

Tabela 3. Tabela de erro vs. condutividade elétrica - Custódio e Llamas (1976)

\begin{tabular}{|l|l|l|l|l|l|}
\hline Erro\% & 30 & 10 & 8 & 4 & $<4$ \\
\hline C.E. $(\mu \mathrm{S} / \mathrm{cm})$ & 50 & 200 & 500 & 2000 & $>2000$ \\
\hline
\end{tabular}

As amostras correspondem aos meses novembro/2011, fevereiro/2012, março/2012; abril/2012; julho/2012; agosto/2012; novembro/2012. A tabela de resultados das análises químicas encontra-se no Apêndice III.

As amostragens com balanço iônico com valores menores ou iguais a $20 \%$ foram considerados no tratamento estatístico, apesar do perfil dos valores de condutividade apresentarem faixa de valores que tolerassem até 30\% de erro, segundo Custódio e Llamas (1981). Tendo isso em mente, as campanhas de novembro 2011 e março 2012 foram descartadas pelo motivo de a primeira apresentar poços com balanços iônicos irregulares e a segunda por valores muito acima da tolerância. 


\subsection{Meteorologia}

Os dados meteorologicos foram obtidos na estação pertencente a UNESP (CEAPLA Centro de Análise e Planejamento Ambiental /IGCE Rio Claro - SP).

A estação localiza se nas coordenadas $-22^{\circ} 39^{\prime} 19^{\prime \prime}$ de latitude e $-47^{\circ} 54^{\prime} 58^{\prime \prime}$ de longitude, e a uma altitude de 626 metros. A partir desses dados foi elaborada uma análise estatística descritiva com a determinação das medidas de tendência central como: média (X) e desvio padrão $\left(S^{2}\right)$, para temperaturas. Os dados encontram-se compilados nos Apêndices I e II.

\subsection{Cálculo de estimativa de recarga}

\subsubsection{Balanço hídrico}

Os dados de precipitação do período estudado foram adquiridos no CEAPLA-UNESP. O termo $Q$ (fluxo de entrada e saída de água) da equação foi desconsiderado, pois o gradiente topográfico é muito baixo e a lagoa não apresenta drenagens superficiais, sendo a chuva a única fonte de entrada de água e a infiltração como saída. O armazenamento na zona não saturada é dado pela diferença entre a capacidade de campo do solo e seu ponto de murchamento em função do tipo e da espessura do solo. Será considerado valor de 200 $\mathrm{mm}$ referente ao solo arenoso.

O termo ET (evapotranspiração) é o termo mais impreciso de ser obtido, pois depende de informações climáticas para ser determinado empiricamente: temperatura média, precipitação, insolação e velocidade de ventos. Para isso, o método proposto por Thornthwaite foi considerado como o que melhor se adequa às condições climáticas de alternância de períodos secos e chuvosos bem definidos (VASCONCELOS, 1996).

$$
E T P=16(10 T / I)^{a}
$$

Onde:

$\mathrm{T}=$ Temperatura média mensal $\left({ }^{\circ} \mathrm{C}\right)$

I = Índice térmico anual 
O índice térmico anual "I" é obtido pela somatória dos índices térmicos mensais dos 12 meses anteriores à medida, que somados, dão o índice térmico anual.

$$
I=\sum_{j=i-12}^{i} I_{i}
$$

Onde: $\quad \mathrm{I}_{\mathrm{i}}=\left(\mathrm{T}_{\mathrm{i}} / 5\right)^{1,514}$

O termo $T_{i}$ corresponde à temperatura média de cada mês do ano. $O$ termo "a" é obtido em função do índice térmico anual:

$$
a=0,49239+1792 \times 10^{-5} \mathrm{I}-771 \times 10^{-7}+675 \times 10^{-9} \mathrm{I}^{3}
$$

Thornthwaite (1948) propôs uma correção para valores de temperaturas médias acima de $26,5^{\circ} \mathrm{C}$ a fim de evitar tendência de superestimar o valor de ETP, porém, como a temperatura média da área de estudos é de $22,5^{\circ} \mathrm{C}$, essa correção não é necessária.

\subsubsection{Flutuação dos níveis potenciométricos}

Neste método, considera-se que o aumento dos níveis de água registrado nos poços de monitoramento da área seja devido à resposta do aquífero local aos eventos de recarga. Este tem sido aplicado por diversos autores por ser relativamente de simples manuseio, versátil e possuir boas respostas (DAMBRÓS e SILVA, 2013; BAUMHARDT et al., 2012; VIVIANI-LIMA, 2007; WAHNFRIED e HIRATA, 2005). Wahnfried e Hirata (2005) também o consideraram o mais sensível quando há a possibilidade de implantação de uma boa rede de monitoramento para a observação do nível de água representativo da área.

Foi considerado o ano hidrológico de novembro de 2011 a novembro de 2012, uma vez que se observou maior variação dos valores dos níveis de água nos poços de monitoramento. A precipitação total desse período foi de $1.620,80 \mathrm{~mm}$, segundo os dados pluviométricos - Anexo I. 
A vazão específica corresponde à razão entre o volume de água drenada por gravidade de uma rocha saturada pelo seu volume total. Neto e Chang (2008) consideraram o valor de Sy igual a 0,17 após conduzirem ensaios de retenção de água no solo, em amostras indeformadas coletadas ao longo de poços cacimba da Formação Rio Claro. Oliva (2002), por meio de descrição de amostra de afloramentos e análise granulométrica, indicou que os arenitos da Formação Rio Claro possuem granulometria que varia de areia fina a média, possuindo partes com alto teor de argila; outros são conglomeráticos, indicando sedimentação em ambiente fluvial. No entanto, dentro dessa classificação, a tabela sugerida por Fetter (2001) atribui valores entre 0,21 e 0,26.

Tabela 4. Vazão específica em \% (Modificado de JOHNSON, 1967, apud FETTER, 2001)

\begin{tabular}{|l|l|l|l|}
\hline Material Geológico & Máximo & Mínimo & Médio \\
\hline Argila & 5 & 0 & 2 \\
\hline Argila arenosa & 12 & 3 & 7 \\
\hline Material Geológico & Máximo & Mínimo & Médio \\
\hline Silte & 19 & 3 & 18 \\
\hline Areia fina & 28 & 10 & 21 \\
\hline Areia média & 32 & 15 & 26 \\
\hline Areia grossa & 35 & 20 & 27 \\
\hline Areia com cascalho & 35 & 20 & 25 \\
\hline Seixo fino & 35 & 21 & 25 \\
\hline Seixo médio & 26 & 13 & 23 \\
\hline Seixo grosso & 26 & 12 & 22 \\
\hline
\end{tabular}

Silva e Farias (2013) aplicaram o método de estimativa de recarga em um aquífero constituído de arenitos médios a finos, intercalado com siltitos argilosos dispostos em lentes, podendo conter bolas de argila, com permeabilidade alta a média, onde a pluviosidade foi de $1.769 \mathrm{~mm}$ para o ano considerado. Observou-se amplo predomínio da fração areia fina seguida da fração silte na faixa de flutuação do nível de água, e, por isso, adotou-se o índice igual a 0,10 . 


\subsubsection{Aproximação Darcyniana}

O método de cálculo da estimativa da recarga por aproximações darcynianas estima o fluxo de água subterrânea que atravessa uma seção determinada do aquífero utilizando a equação de Darcy, de acordo com a condutividade hidráulica e o caminho percorrido pela água.

Lei de Darcy:

$$
Q=K \cdot i \cdot A
$$

Onde:

$\mathrm{Q}=\operatorname{Vazão}(\mathrm{L} 3 / \mathrm{T})$;

$\mathrm{K}=$ condutividade hidráulica $(\mathrm{L} / \mathrm{T})$;

$\mathrm{i}=$ gradiente hidráulico $(\mathrm{dh} / \mathrm{dL})$;

$A=b . L=$ área da seção, sendo $b$ a espessura saturada e $L$ a largura em planta da seção

A vazão através de uma seção do aquífero corresponde à taxa de recarga:

$$
\mathrm{Q}=\mathrm{RM}
$$

Onde:

$\mathrm{R}=$ taxa de recarga $(\mathrm{L} / \mathrm{T})$;

$M=$ área da superfície que contribui para a recarga (L2)

Considera-se que a vazão que passa por essa determinada área seja uma estimativa equivalente à recarga da área, e para isso, calculou-se o gradiente hidráulico correspondente à época úmida e seca.

O método é fácil de usar quando existem dados sobre o gradiente hidráulico e a condutividade hidráulica, porém há um alto grau de incerteza devido à grande variabilidade desta última (SCANLON et al., 2002).

Para a aplicação da estimativa darcyniana com base em dados de campo, normalmente assumem-se condições de estado estacionário, assim são somente necessários 
dados de carga hidráulica e condutividade hidráulica para aplicar a equação de Darcy. A escala de tempo para aplicação da aproximação darcyniana pode variar entre episódica, para eventos de precipitação com variação de cargas, até centenas de anos (LERNER, 1990; SCANLON et al., 2002). Lerner (1990) ainda mencionou que fluxos verticais causados por camadas de condutividade hidráulica menor inviabilizam a avaliação da recarga por esse método em períodos inferiores a um ano, devido à alteração no fluxo causado pelo armazenamento de água. O tamanho ideal da área de estudo varia entre alguns quilômetros e milhares de quilômetros quadrados (SCANLON et al. 2002).

Wahnfried e Hirata (2005) utilizaram esse método para estimativa de recarga em uma planície aluvionar da Bacia do Tietê e observaram que o método de aproximação darcyniana é bastante sensível a variações de condutividade hidráulica, sendo a determinação desta a etapa mais importante no processo. A escala espacial é outro limitante, uma vez que a imprecisão aumenta com a diminuição das distâncias entre poços. 


\subsection{Geofísica}

Métodos geofísicos também foram aplicados, em caráter complementar, a fim de se entender a dinâmica hidrogeológica da área de estudo. Os métodos utilizados foram: Potencial Espontâneo (SP) e eletrorresistividade através das técnicas de Sondagem Elétrica Vertical (SEV) e Caminhamento Elétrico (CE).

O levantamento geofísico incluiu seis perfis de caminhamento elétrico feitos em julho e setembro de 2013 , antes e após a colheita de eucalipto, respectivamente. Incluiu também nove SEV, que indicaram a profundidade do aquífero e ajudaram na interpretação de resultados do caminhamento elétrico, além de um levantamento pelo método de SP.

As linhas de CE foram realizadas usando configuração dipolo-dipolo e espaçamentos de 5 metros para os perfis 1,2 e 3 , e de 2,5 metros para os perfis 4,5 e 6 , permitindo investigar 10 níveis, resultando em até 915 dados para cada seção.

As SEVs foram realizadas com AB/2 (distância máxima entre eletrodos) de 50 a 80 metros, investigando mais de 20 metros de profundidade em alguns pontos.

Para a aquisição dos dados de Potencial Espontâneo, foi utilizada a Técnica dos Potenciais ou Base Fixa, com um eletrodo mantido fixo em uma estação-base, enquanto outro percorreu pontos de medida a cada 10 metros ao longo das linhas 1,2 e 3 do caminhamento elétrico e entre as mesmas. 


\section{Resultados}

\subsection{Características da área}

A topografia da área apresenta uma declividade de noroeste para sudeste (Figura 6). O ponto mais a montante corresponde à linha de alta tensão, e o a jusante, ao lago. Os valores das cotas topográficas variam entre $620,0 \mathrm{msnm}$ (metros sobre o nível do mar) e 628,5 msnm, gerando uma diferença de altitude de 8,5 metros entre a menor e a maior cota e uma inclinação do terreno de 3 graus.

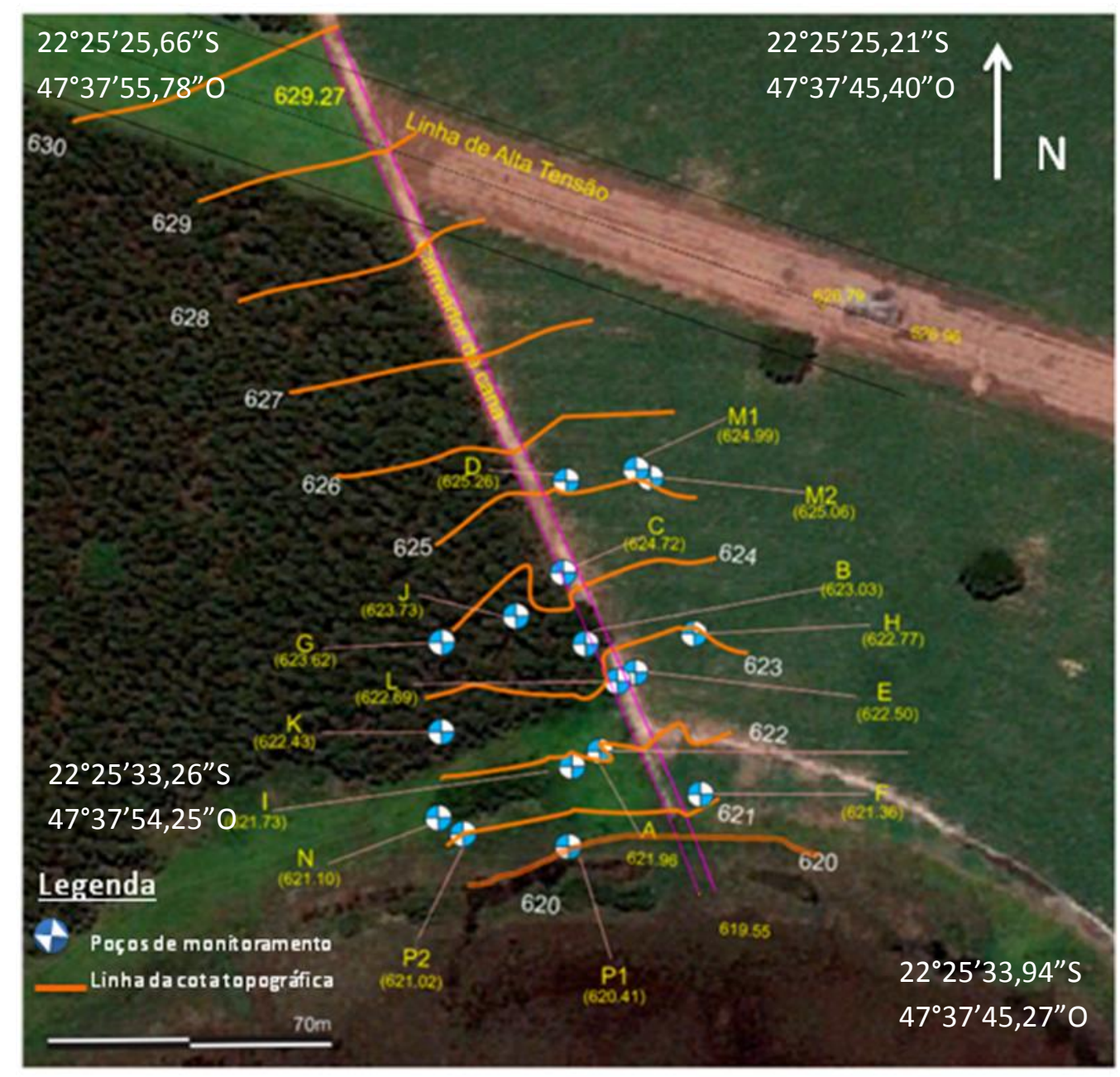

Figura 8. Topografia da área de estudos sobre imagem Google (2012) 
Pode-se considerar que, de modo geral, os sedimentos da Formação Rio Claro são, predominantemente, arenosos, vermelhos, ocres, amarelados, esbranquiçados e róseos, mal consolidados em superfície, com solo (latossolo areno-argiloso) bastante desenvolvido (8 a $12 \mathrm{~m}$ de espessura) nos altos topográficos (topo dos interflúvios). São comuns as intercalações de lentes argilosas brancas e vermelhas, laminadas, por vezes abaixo de camadas de areia fina branca e também de níveis conglomeráticos, começando a profundidades de 10 a $13 \mathrm{~m}$. Nas sondagens dos poços 70, 80 e 90, mais distantes da lagoa (aproximadamente $400 \mathrm{~m}$ ), em cota entre 628 e $630 \mathrm{~m}$ e em profundidade de até $20 \mathrm{~m}$, foram encontrados perfis semelhantes aos observados por Zaine (1994) e Oliva (2002) em suas contribuições sobre a dinâmica dessas lagoas.

Uma avaliação a partir da análise das amostras de sedimentos coletadas durante perfurações dos poços de monitoramento para esse estudo, todos locados em distâncias de, aproximadamente, 50 metros do corpo de água, permitiu a identificação de três camadas distintas correlacionadas aos sedimentos da Formação Rio Claro, porém com presença de muita matéria orgânica na parte superior do solo (cor escura):

1. A primeira camada corresponde a um solo de fração areno-argilosa (areia fina a grossa), mal selecionado, de coloração marrom escura a marrom clara, com presença de matéria orgânica. Essa camada tem espessura de 0 a $3 \mathrm{~m}$, dependendo da cota topográfica, sendo que à medida que se caminha em direção ao lago, intensifica-se a presença de argila e de matéria orgânica;

2. A segunda camada possui coloração que varia desde marrom mais claro a avermelhada. A granulação é mais fina e é maior a presença de argila em relação ao intervalo anterior;

3. Logo abaixo, tem-se a terceira camada, coloração avermelhada, predominantemente argilosa, sem matéria orgânica.

A temperatura média é de $22,5^{\circ} \mathrm{C}$ (tendo como valores mínimos e máximos $15,4^{\circ} \mathrm{C} \mathrm{e}$ $26,9^{\circ} \mathrm{C}$, respectivamente). Deve ser enfatizado que, para a determinação das temperaturas, foram considerados os dados no período de 9 anos (1994-2003), os únicos registrados na estação. 
Com o intuito de se obter as tendências pluviométricas da área, foram homogeneizados os dados das estações avaliadas (Anexo I) no período de 20 anos, obtendose, assim, as médias multianuais para cada uma das estações pluviométricas.

Os resultados obtidos com os dados do CEAPLA acompanharam as tendências das faixas observadas por Troppmair: a precipitação apresenta uma distribuição heterogênea temporal, com maiores precipitações no mês de janeiro $(320,00 \mathrm{~mm})$, contrastando com o mês de agosto, quando chega a um valor mínimo de 25,82 mm (Figura 7), e a média dos valores acumulados entre abril e setembro foi igual a $334,2 \mathrm{~mm}$, e entre outubro e março igual a $1187,2 \mathrm{~mm}$.

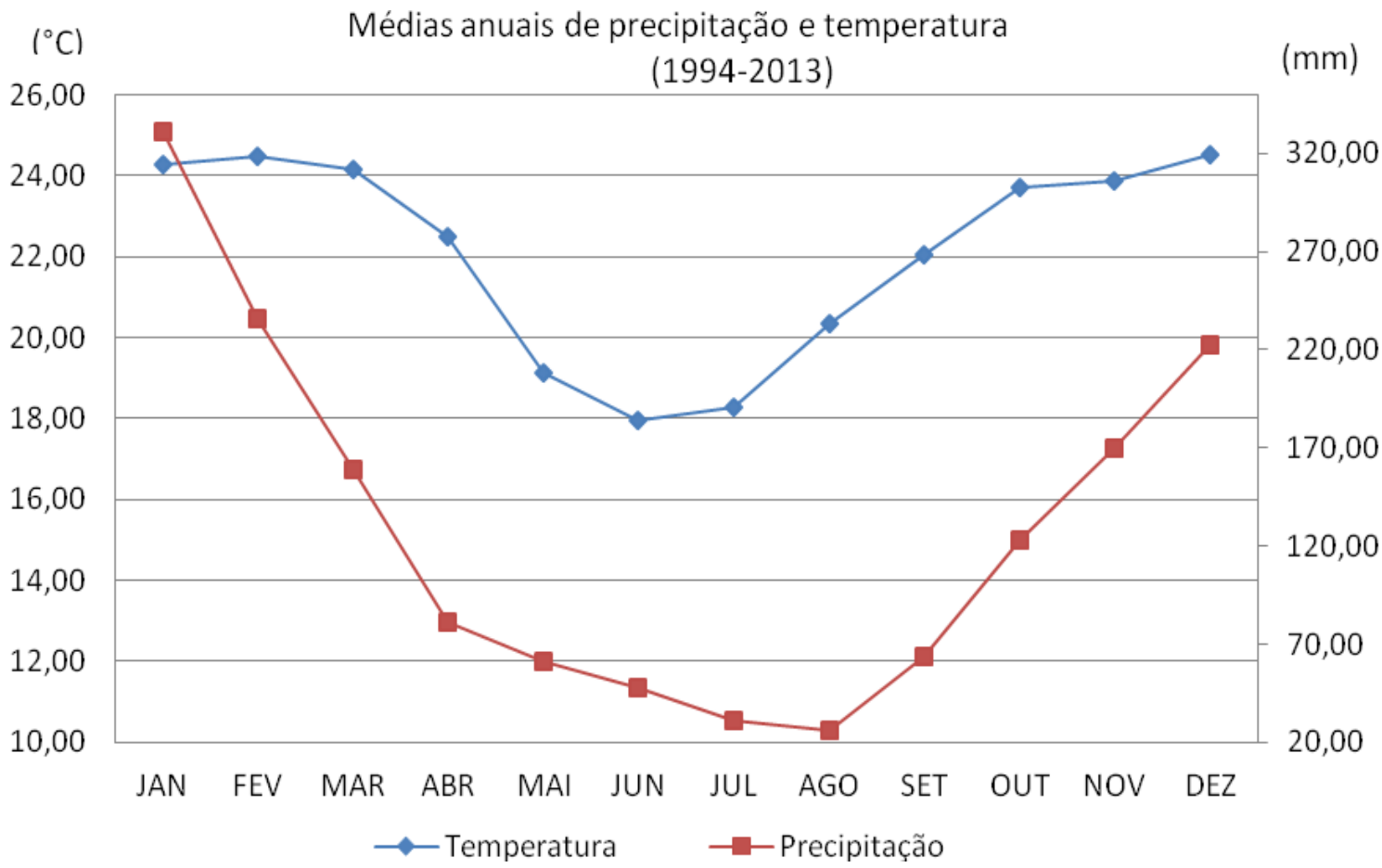

Figura 9. Relação da precipitação e temperatura na área de estudo (Estação meteorológica CEAPLA/UNESP/IGCE, Rio Claro, de 1994 a 2003)

A partir da análise chegou-se a 1521,40 mm de precipitação média multianual para a área de estudo. 


\subsection{Fluxo das águas subterrâneas}

\subsubsection{Avaliação da variação dos níveis dos poços no tempo com as chuvas}

Os poços $A, B, C, D, E$ e $F$ foram os primeiros a serem construídos e, por isso, apresentam a maior sequência de dados, entre novembro de 2011 e março de 2013 (Figura 8). De acordo com essa figura, pode-se observar uma tendência geral de decréscimo do nível de água, mesmo passando por um período de chuva (verão) no primeiro terço, estiagem (inverno) no segundo terço e chuva (verão) no terceiro terço.

Comparando os meses de novembro de 2011 e novembro de 2012, observou-se um rebaixamento de $37 \%, 33 \%, 9 \%, 93 \%$ e $23 \%$ nos níveis de água dos poços $A, B, C, D$ e $E$, e aumento de $14 \%$ no poço $\mathrm{F}$. Semelhantemente, pode-se observar a mesma tendência na comparação dos meses de abril de 2012 e abril de 2013, quando os mesmos poços rebaixaram seus níveis em $41 \%, 34 \%, 27 \%, 8 \%, 39 \%$ e $60 \%$. Esse fato também pode ser observado pelo índice pluviométrico para o mês de novembro de 2011 e 2012 da Estação Meteorológica de Rio Claro (CEPLA), que registrou 188,3 mm de chuvas em novembro de 2011 , contra $92,5 \mathrm{~mm}$ de chuva em novembro de 2012 , o que representa uma baixa de aproximadamente $50 \%$ (Figura 8 ).

A queda dos índices pluviométricos no período de junho a outubro de 2012 levou à diminuição da recarga, gerando rebaixamento do nível de água e, por consequência, inutilizou cerca de $70 \%$ dos poços, levando-os ao secamento.

Paralelamente, alguns poços encontraram-se preenchidos por argila, e, em outros, foi flagrada a presença de raízes finas, provavelmente do eucalipto, que é a única espécie de grande porte da área de estudo.

A figura abaixo (Figura 8) apresenta a queda dos níveis de água, cuja tendência é detectada em todos os poços. Ao mesmo tempo, também se observa queda nos excedentes hídricos, o que diminui a recarga efetiva. 


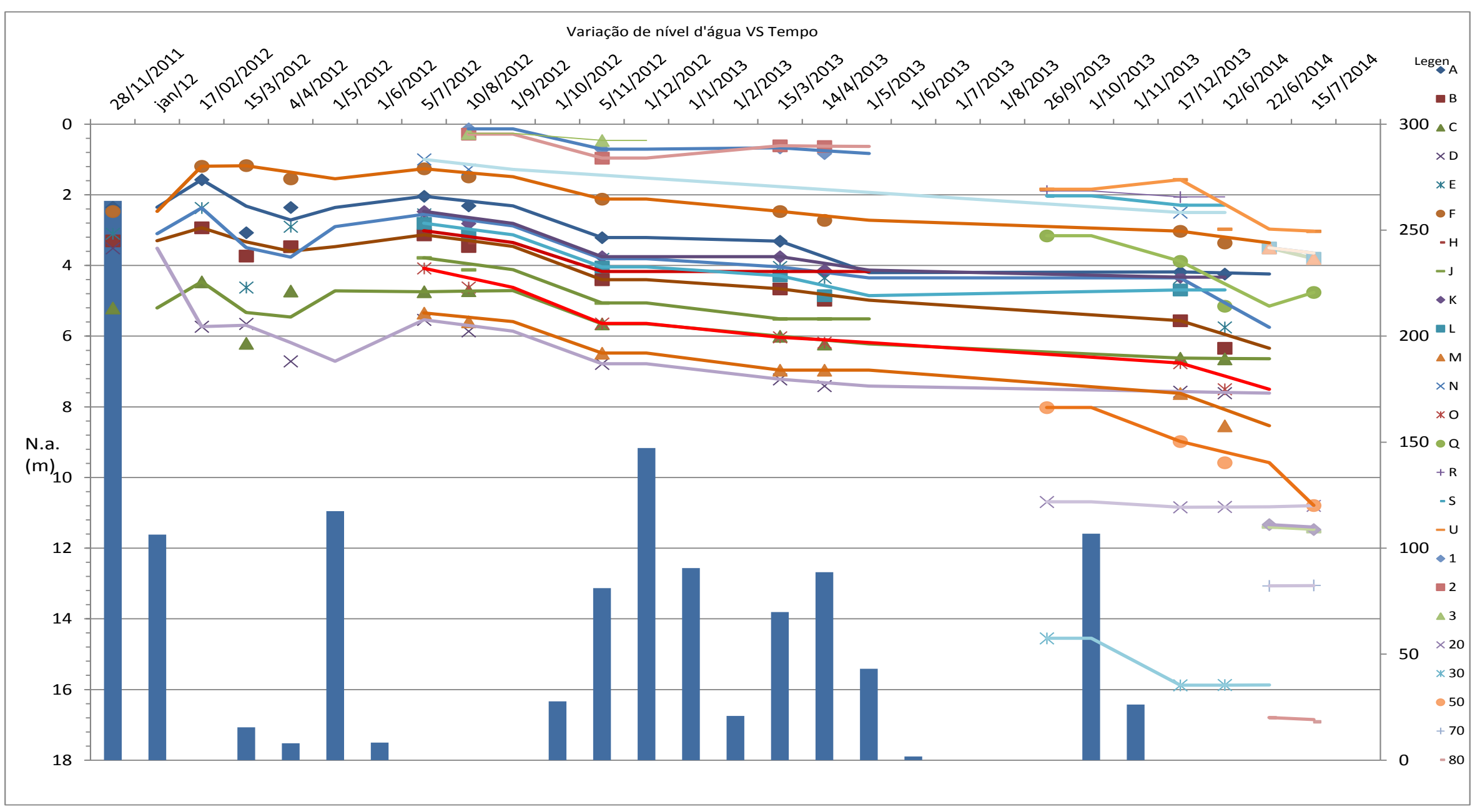

Figura 10. Variação temporal do nível de água em poços de monitoramento e a recarga potencial de estudo. 
O poço $\mathrm{H}$ encontra-se na plantação de cana-de-açúcar, e é nítida a queda do nível de água acompanhado do aumento da condutividade elétrica, compreendendo justamente o período de julho a dezembro de 2012, quando o potencial de recarga é muito baixo (Figura 9).

\section{Pressão submersa}

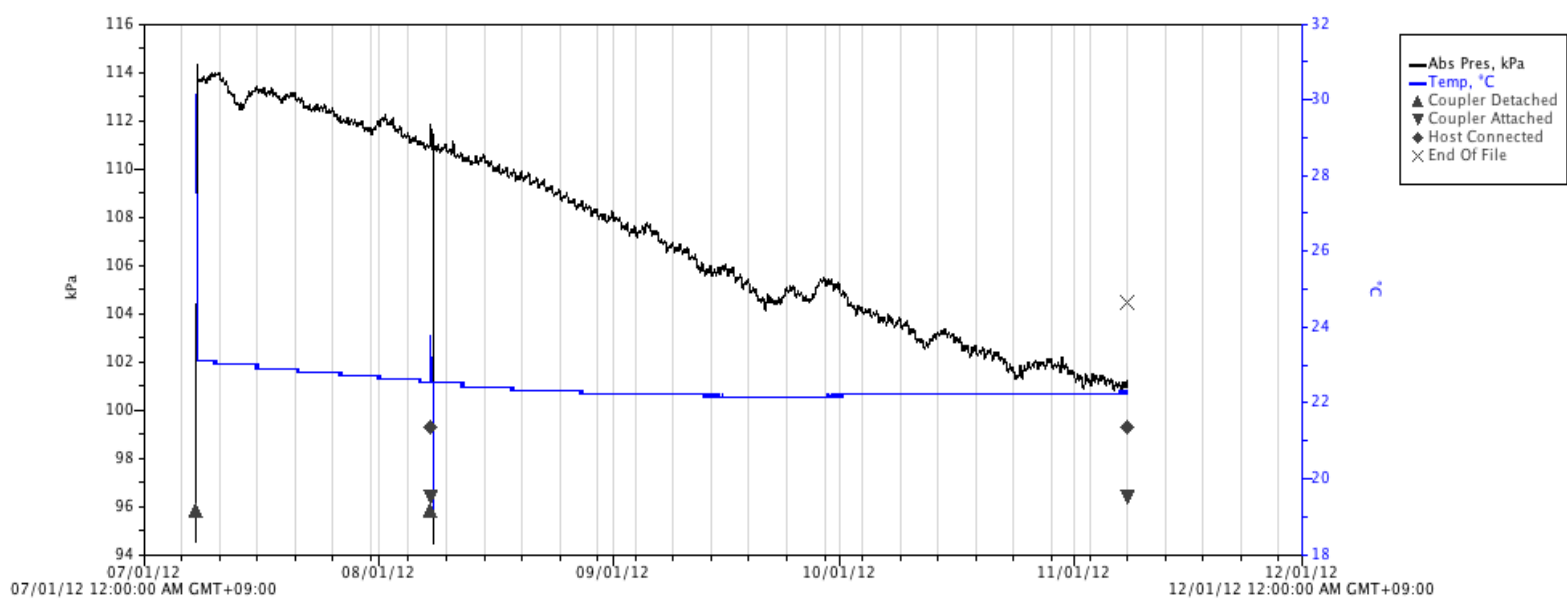

Condutividade elétrica

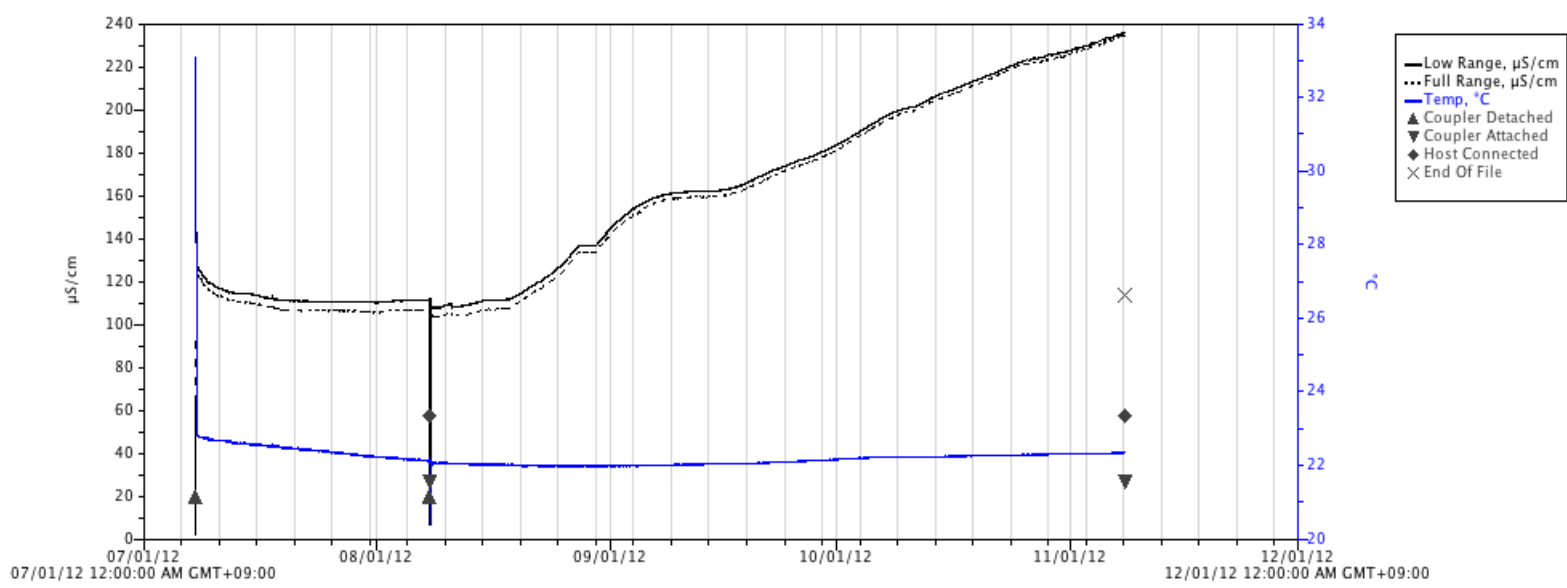

Figura 11. Variação de pressão/ nível de água e condutividade elétrica do poço H

O poço G encontra-se na parte de eucalipto, e foi possível monitorá-lo durante março de 2012 a novembro de 2012, quando foi danificado e retirado para manutenção. Pode-se observar que a pressão exercida pela água apresentou um pequeno decréscimo durante o período, o que significa que houve rebaixamento do nível de água. A subida repentina da condutividade elétrica em meados da primeira quinzena pode ser relacionada aos danos 
sofridos. Após o conserto da estrutura do poço, o mesmo se apresentou seco, impossibilitando reinstalar o datalogger.

\section{Pressão submersa}

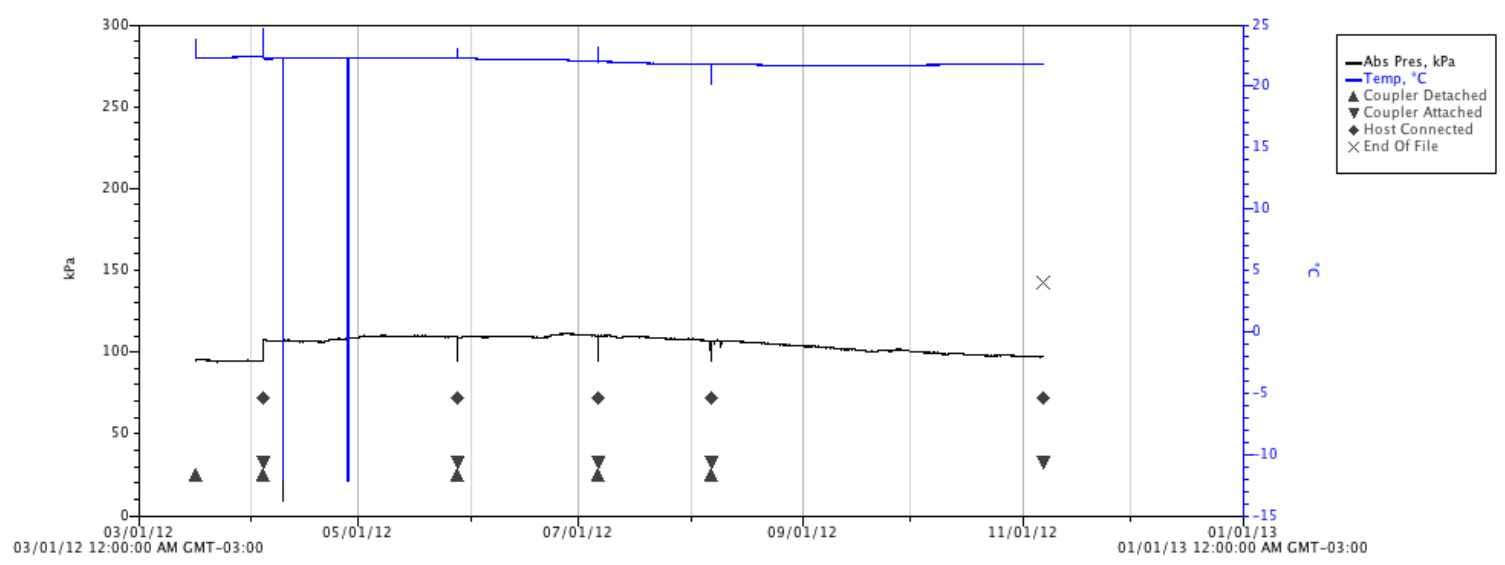

\section{Pressão atmosférica}

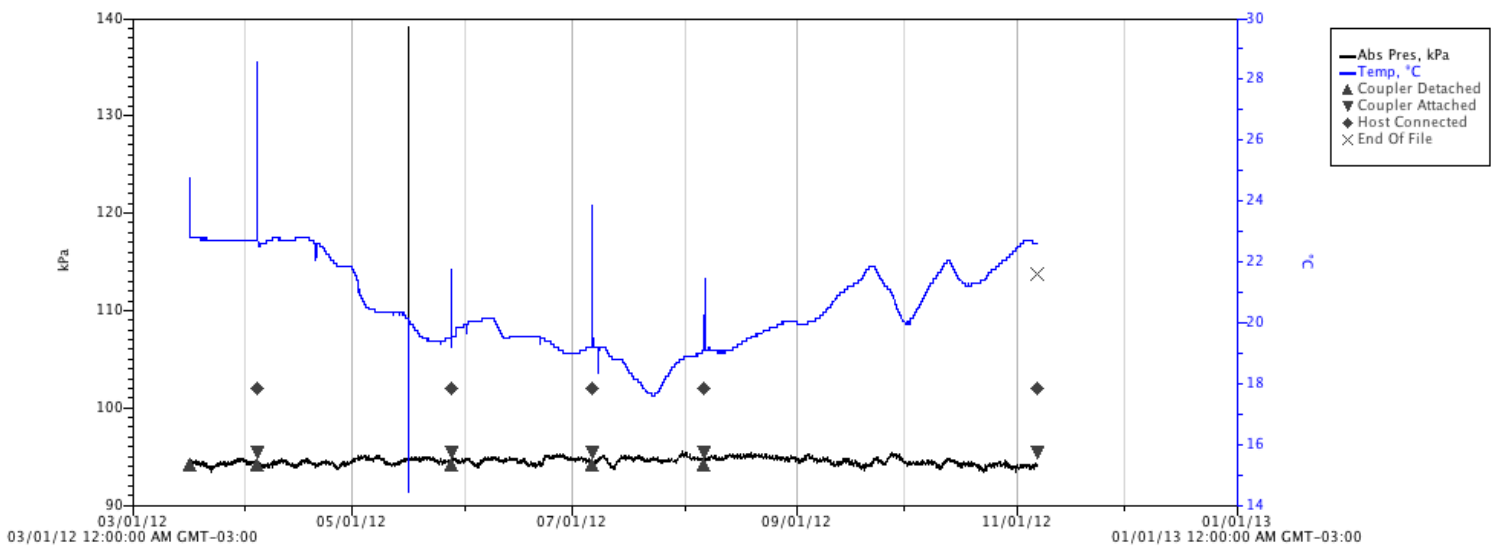

\section{Condutividade elétrica}

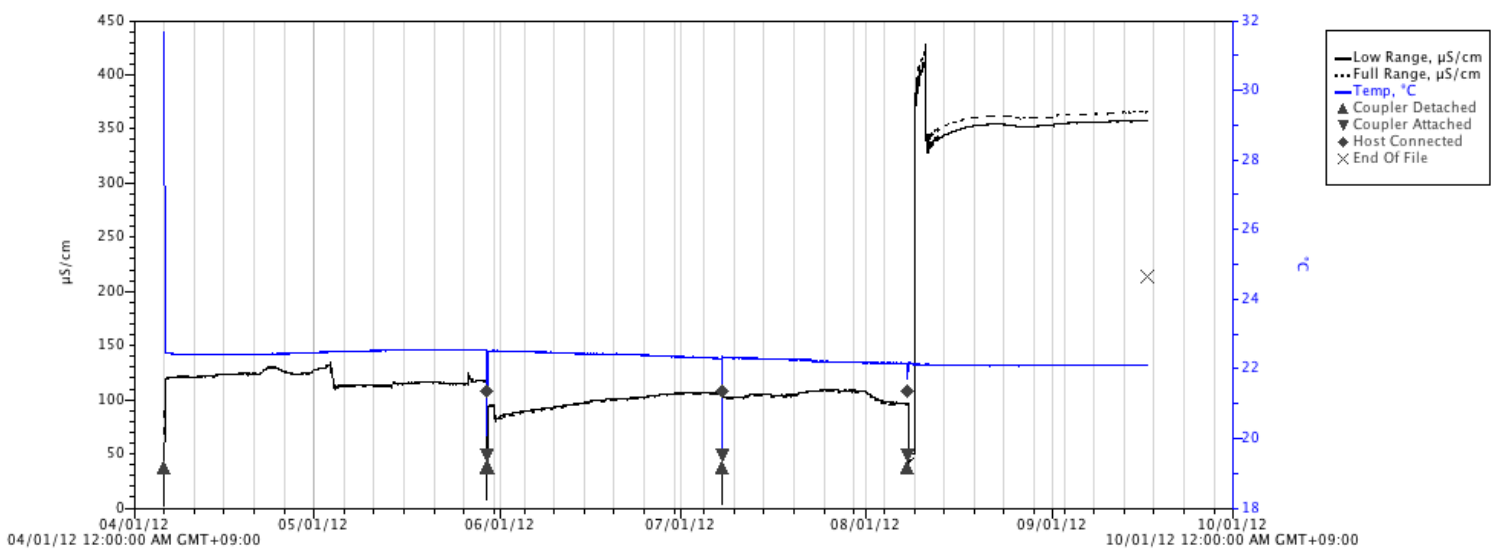

Figura 12. Variação de pressão/ nível de água e condutividade elétrica do poço G 
Um terceiro poço de monitoramento foi construído nos arredores do poço $\mathrm{G}$ a fim de recuperar o monitoramento, com isso, foi instalado no poço $\mathrm{P}$ pelo período de setembro de 2013 e setembro de 2014, e os resultados desse monitoramento encontram-se na Figura 11. Pode-se observar que, logo após janeiro/14, houve uma elevação da pressão submersa. Essa pressão caiu e se estabilizou a partir de julho/14. Paralelamente, no mesmo período, o sinal da condutividade elétrica aumentou, indicando salinização da água até queda brusca na metade do mês de maio/14. A queda desse sinal está relacionada com o secamento do poço, que provavelmente acompanha a escassez de água regional.

\section{Pressão atmosférica}

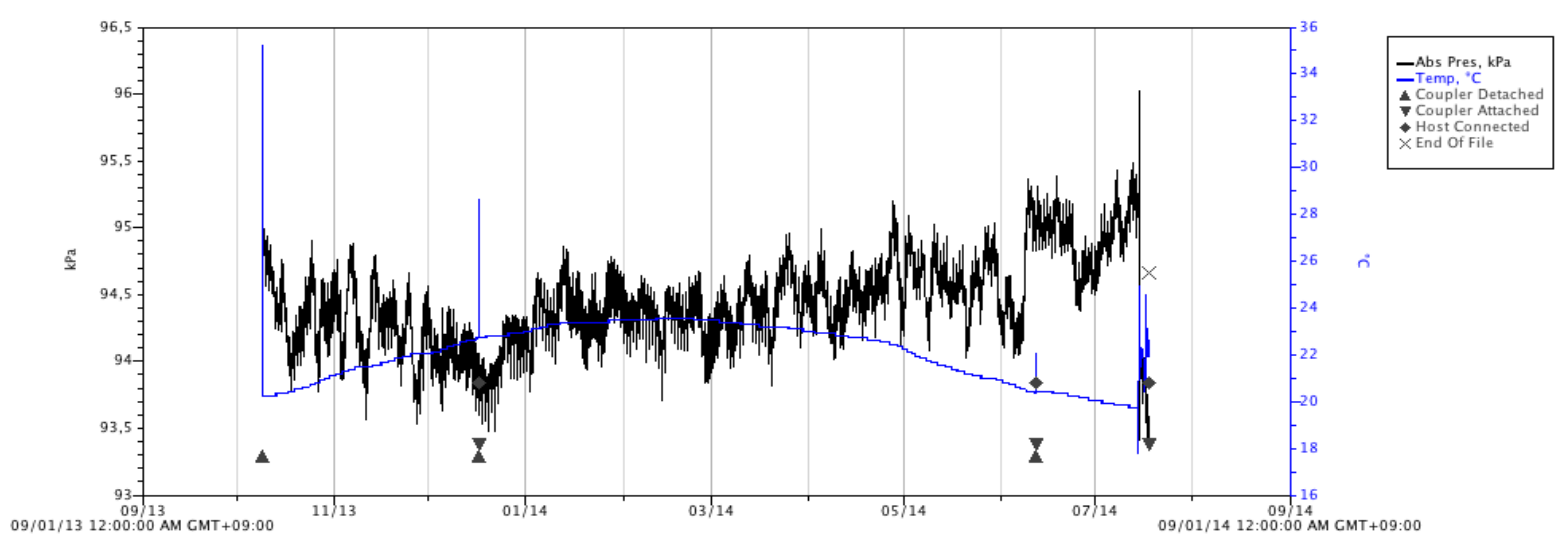

Pressão submersa

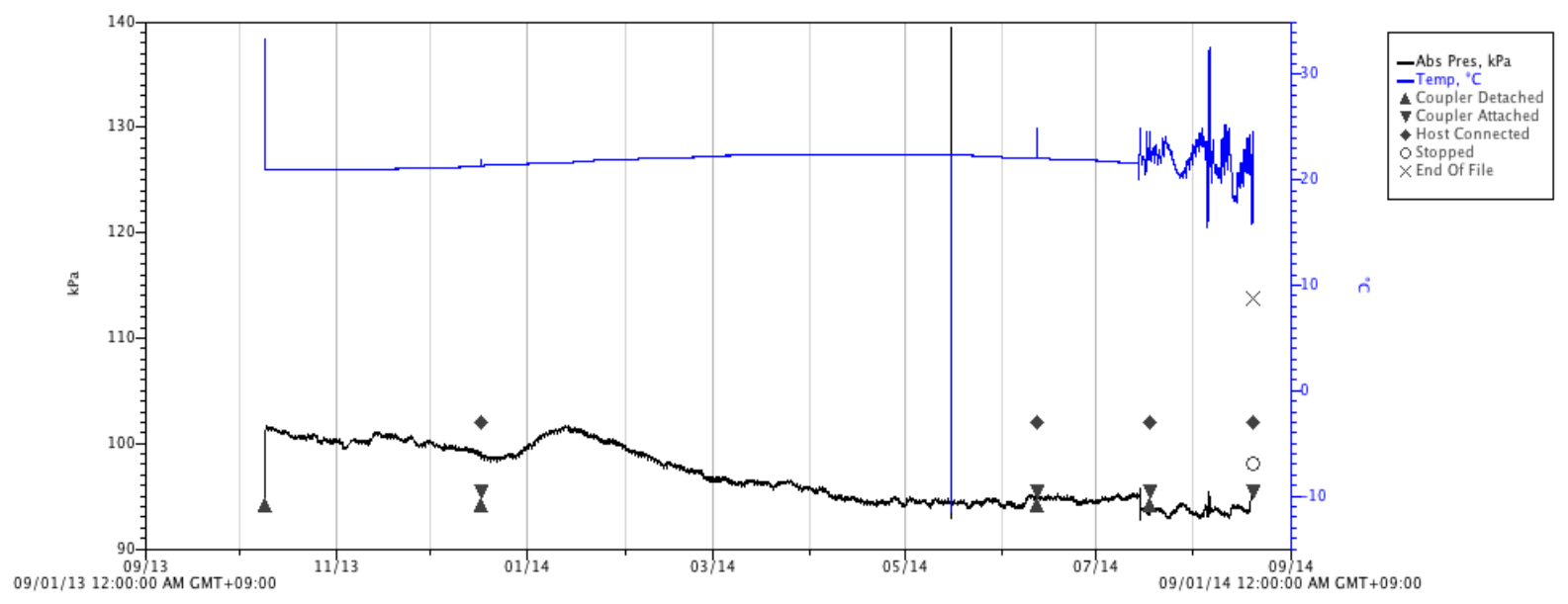


Condutividade elétrica

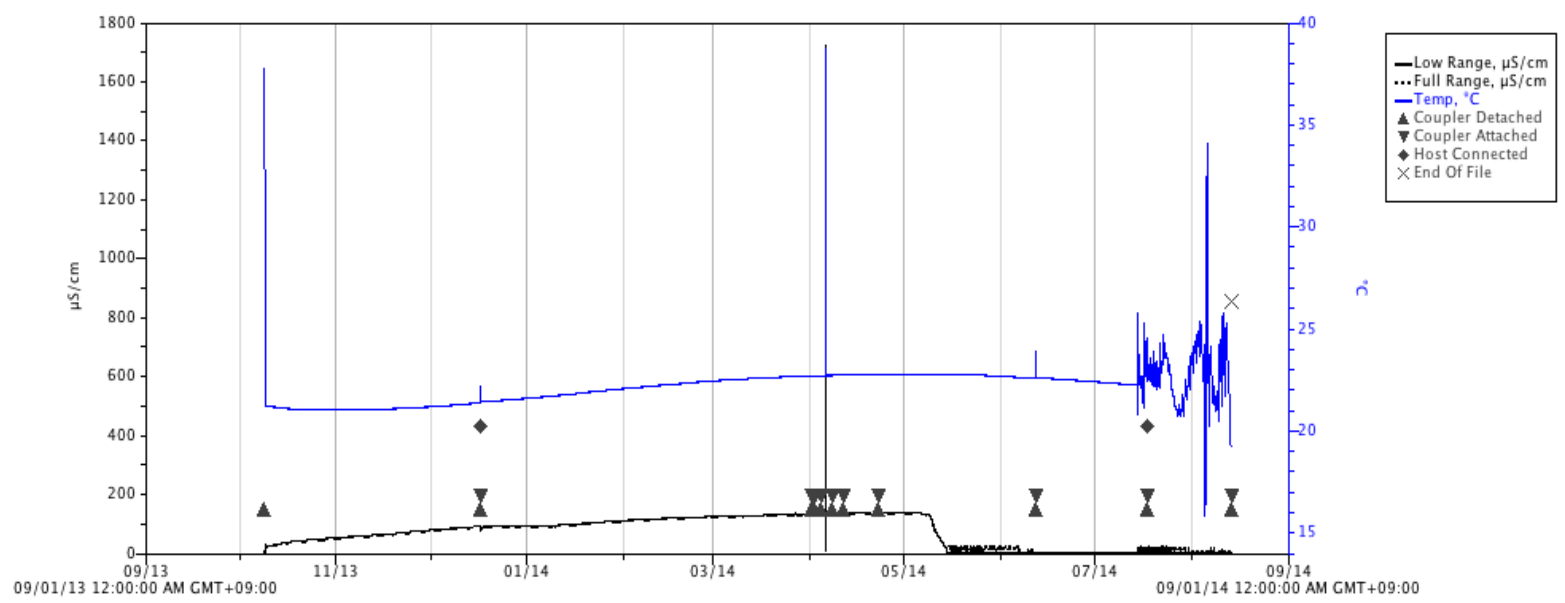

Figura 13. Variação de pressão/ nível de água e condutividade elétrica do poço $P$

\subsection{Mapa potenciométrico}

O mapa potenciométrico descreve o sentido do fluxo da água subterrânea relativo aos meses de coletas de dados. Contrariamente à topografia, notou-se que a água flui de jusante até montante, saindo do lago para a parte mais alta da topografia, com uma leve inclinação no sentido S-SE para N-NO e descargas associadas às drenagens ou nascentes locais (Figura 13).

Esse comportamento foi notado desde o início da pesquisa, mas foi atribuído ao regime de chuvas e à evapotranspiração dos eucaliptos, que poderiam influenciar os fluxos. A regularidade entre as cargas hidráulicas dos poços com o tempo (Figura 8) mostrou que a direção de fluxo não se altera significativamente ao longo das estações, mesmo depois do corte dos eucaliptos (agosto de 2013). Assim, o padrão de fluxo é muito mais controlado pela situação topográfica da lagoa em relação às drenagens circunvizinhas.

Em termos locais, o lago está situado no topo de uma colina de topo amplo, comportando-se como uma zona de recarga, pois o valor do potencial hidráulico relativo ao nível da água de sua superfície é maior que as das nascentes e drenagens à sua volta. 


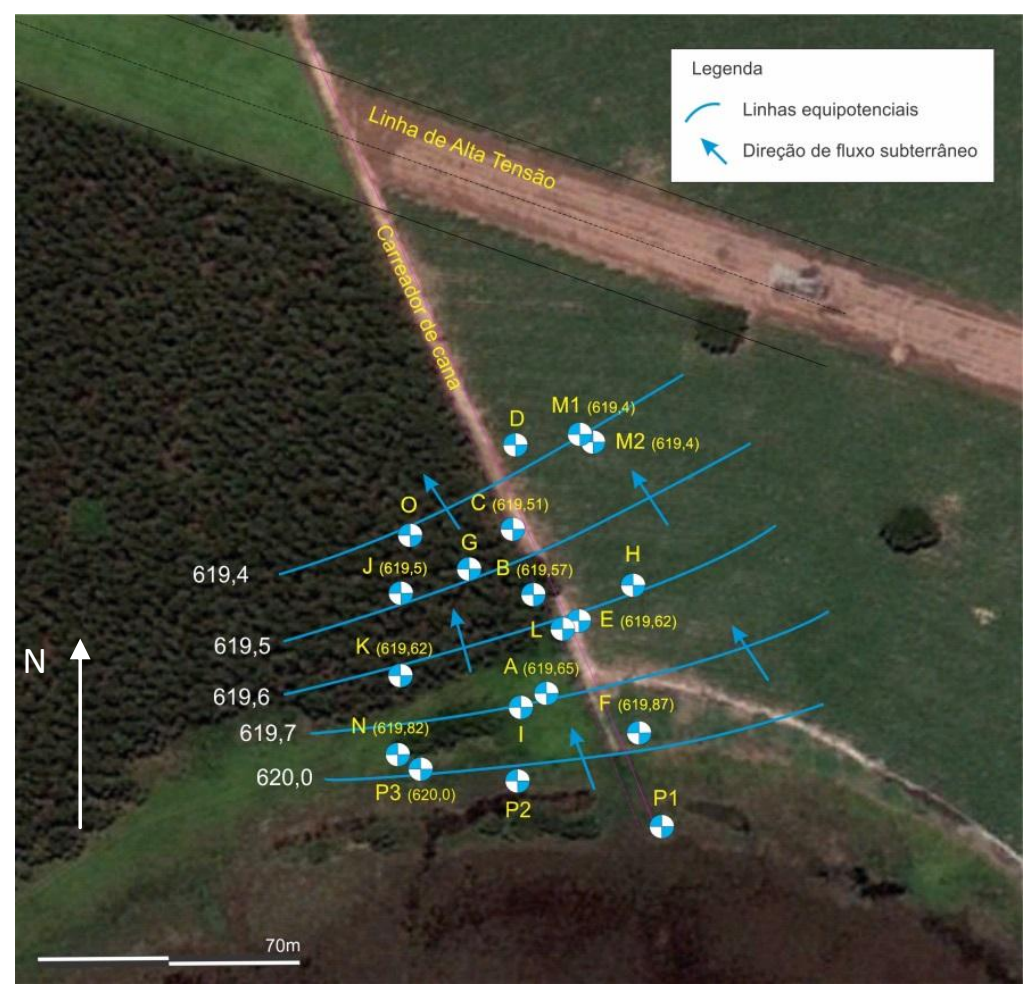

Figura 14. Mapa potenciométrico relativo à campanha de agosto 2012

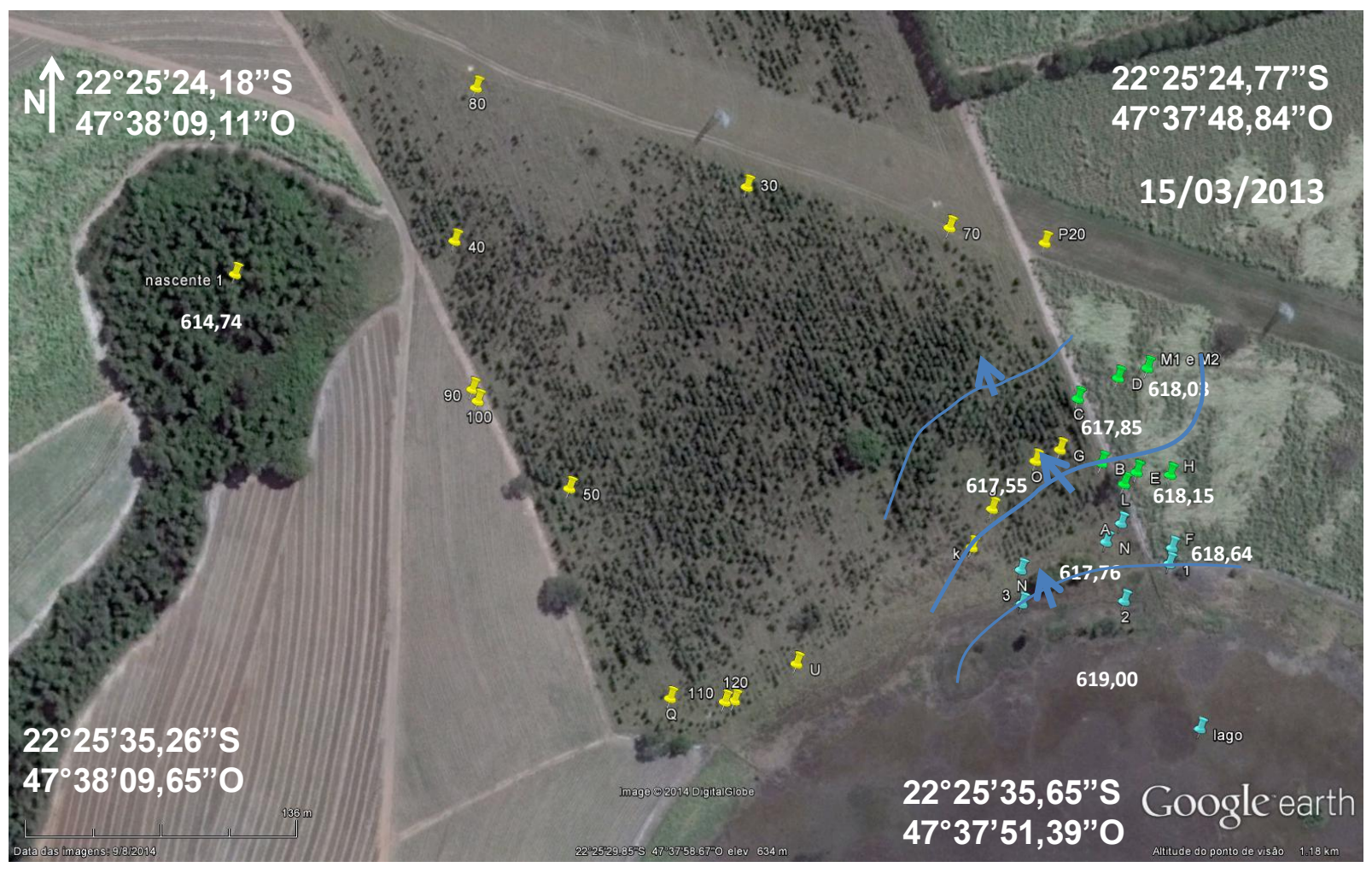



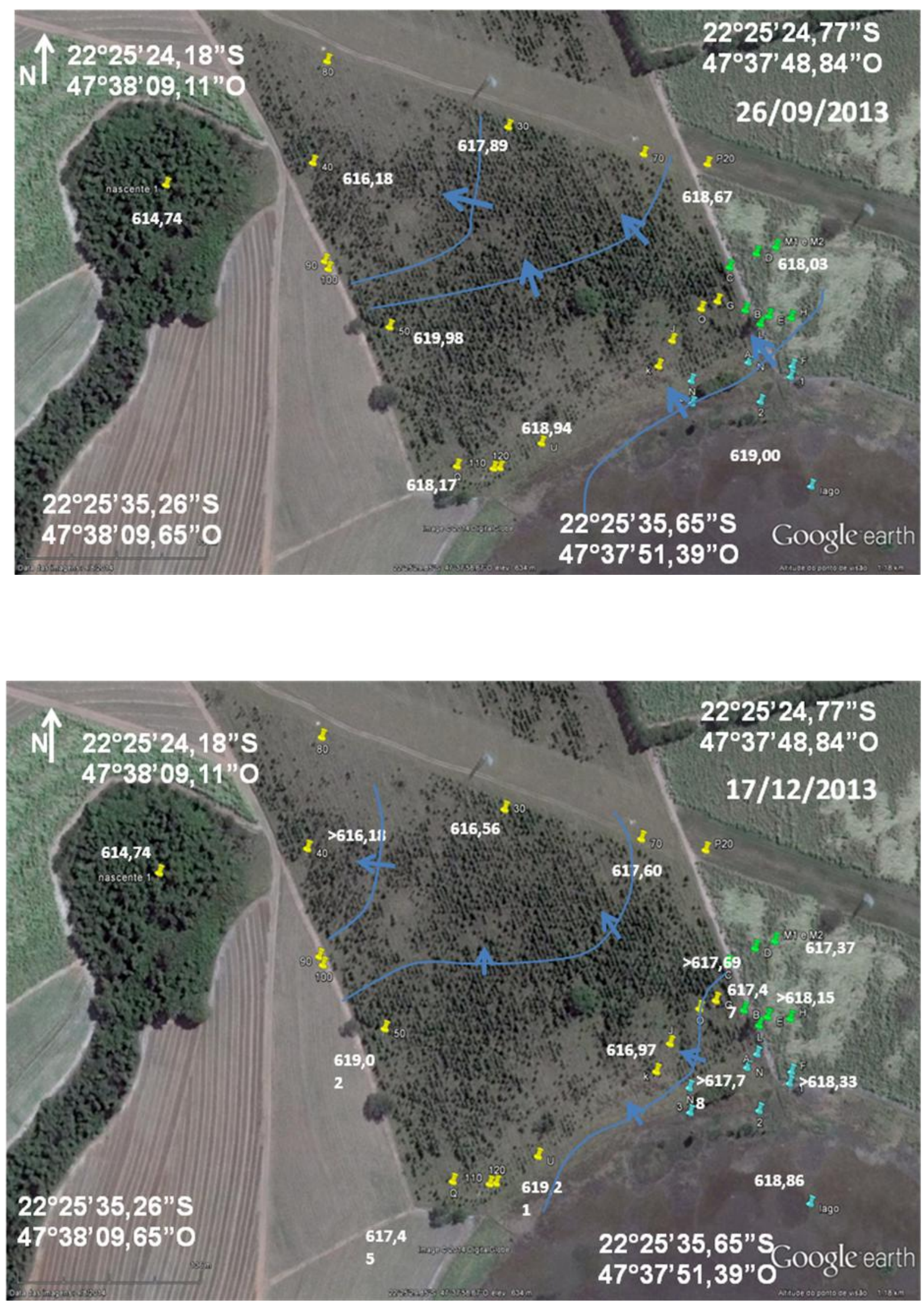

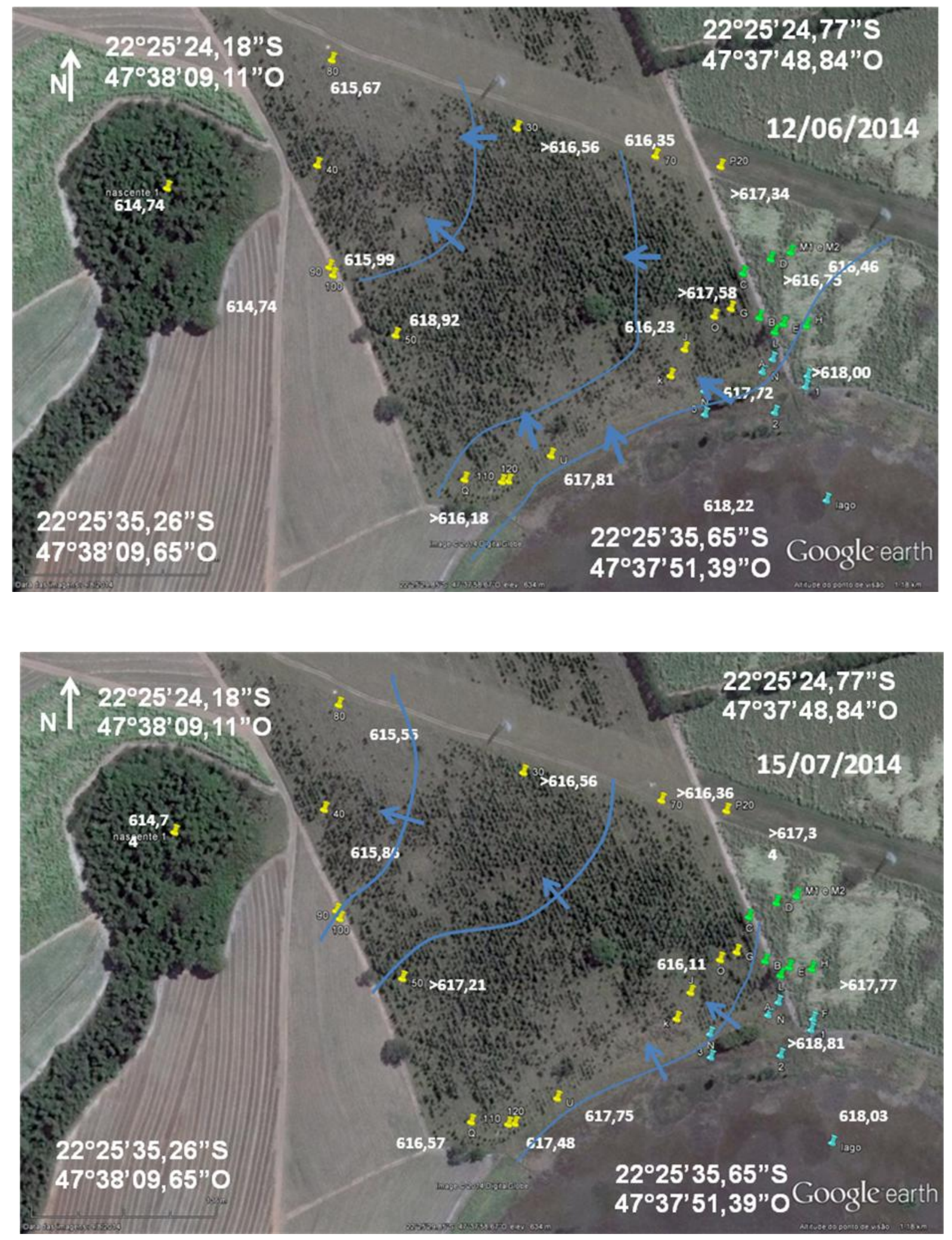

Figura 15. Mapas potenciométricos em diferentes datas 


\subsection{Cálculo da estimativa de recarga}

A estação meteorológica levada em conta como referência para a avaliação encontrase localizada nas coordenadas $22^{\circ} 39^{\prime} 19^{\prime \prime} \mathrm{S}$ de latitude e $-47^{\circ} 54^{\prime} 58^{\prime \prime} \mathrm{O}$ de longitude, e altitude de $626 \mathrm{~m}$. A partir desses dados foi elaborada uma análise estatística descritiva com a determinação das medidas de tendência central como: média $(X)$ e desvio padrão $\left(S^{2}\right)$, para os parâmetros de precipitações e temperaturas. O cálculo da estimativa de recarga foi feito por três métodos: Variação dos níveis de água, Balanço hídrico de umidade no solo (Método de Thornthwaite), Aproximação Darcyniana e Isótopos estáveis de Hidrogênio Deutério e Oxigênio-18.

\subsubsection{Balanço hídrico}

O quadro abaixo mostra os valores dos cálculos da evapotranspiração potencial (ETP) e recarga $(R)$ :

Tabela 5. Valores do cálculo da recarga e evapotranspiração pelo método de Thornthwaite, dezembro 2011 a novembro 2012.

\begin{tabular}{|c|c|c|c|c|c|c|c|c|c|c|c|c|}
\hline Mês & $\begin{array}{l}\mathrm{T} \\
\mathrm{oC}\end{array}$ & $\begin{array}{l}P \\
\mathrm{~mm}\end{array}$ & $\begin{array}{l}\text { Núm. } \\
\text { horas }\end{array}$ & 1 & $\begin{array}{l}\text { ETP } \\
\text { Thornthwaite } \\
1948\end{array}$ & $\begin{array}{l}\text { P-ETP } \\
\mathrm{mm}\end{array}$ & NEG-AC & $\begin{array}{l}\text { ARM } \\
\mathrm{mm}\end{array}$ & $\begin{array}{l}\text { ALT } \\
\mathrm{mm}\end{array}$ & $\begin{array}{l}\text { ETR } \\
\mathrm{mm}\end{array}$ & $\begin{array}{l}\text { DEF } \\
\mathrm{mm}\end{array}$ & $\begin{array}{l}\text { EXC } \\
\mathrm{mm}\end{array}$ \\
\hline Dez & 25,0 & 193,9 & 13,3 & 11,4 & 136,06 & 57,8 & $-28,5$ & 173,40 & 57,84 & 136,1 & 0,0 & 0,0 \\
\hline Jan & 21,8 & 362,4 & 13,0 & 9,3 & 95,17 & 267,2 & 0,0 & 200,00 & 26,60 & 95,2 & 0,0 & 240,6 \\
\hline Fev & 24,4 & 223,7 & 12,4 & 11,0 & 107,63 & 116,1 & 0,0 & 200,00 & 0,00 & 107,6 & 0,0 & 116,1 \\
\hline Mar & 23,2 & 73,1 & 11,8 & 10,2 & 100,24 & $-27,1$ & $-27,1$ & 174,62 & $-25,38$ & 98,5 & 1,8 & 0,0 \\
\hline Abr & 22,0 & 132,2 & 11,1 & 9,4 & 80,70 & 51,5 & 0,0 & 200,00 & 25,38 & 80,7 & 0,0 & 26,1 \\
\hline Mai & 18,1 & 61,0 & 10,7 & 7,0 & 50,06 & 10,9 & 0,0 & 200,00 & 0,00 & 50,1 & 0,0 & 10,9 \\
\hline Jun & 18,0 & 166,2 & 10,7 & 7,0 & 47,51 & 118,7 & 0,0 & 200,00 & 0,00 & 47,5 & 0,0 & 118,7 \\
\hline Jul & 17,0 & 52,0 & 11,0 & 6,4 & 44,07 & 7,9 & 0,0 & 200,00 & 0,00 & 44,1 & 0,0 & 7,9 \\
\hline Ago & 19,0 & 0,0 & 11,6 & 7,5 & 60,78 & $-60,8$ & $-60,8$ & 147,59 & $-52,41$ & 52,4 & 8,4 & 0,0 \\
\hline Set & 21,1 & 45,4 & 12,3 & 8,8 & 80,24 & $-34,8$ & $-95,6$ & 123,99 & $-23,60$ & 69,0 & 11,2 & 0,0 \\
\hline Out & 24,1 & 122,6 & 12,9 & 10,8 & 120,06 & 2,5 & $-91,6$ & 126,53 & 2,54 & 120,1 & 0,0 & 0,0 \\
\hline Nov & 23,3 & 92,5 & 13,3 & 10,3 & 110,64 & $-18,1$ & $-109,7$ & 115,56 & $-10,97$ & 103,5 & 7,2 & 0,0 \\
\hline TOTAIS & 257,0 & 1525,0 & 144,0 & 109,2 & 1033,15 & 491,8 & & 2062 & 0,00 & 1004,6 & 28,5 & 520,4 \\
\hline MÉDIAS & 21,4 & 127,1 & 12,0 & 9,1 & 86,10 & 41,0 & & 171,8 & & 83,7 & 2,4 & 43,4 \\
\hline
\end{tabular}

Nota: $\mathrm{P}$ = precipitação; $\mathrm{T}$ = temperatura; $\mathrm{N}$ = horas do dia; $\mathrm{I}$ = índice térmico; $\mathrm{ETP}$ = evapotranspiração potencial; $A R M=$ armazenamento; $D E F$ = déficit; $A L T$ = variação do armazenamento; $E X C$ = excedente. 


\section{Balanço Hídrico Normal Mensal 2012}

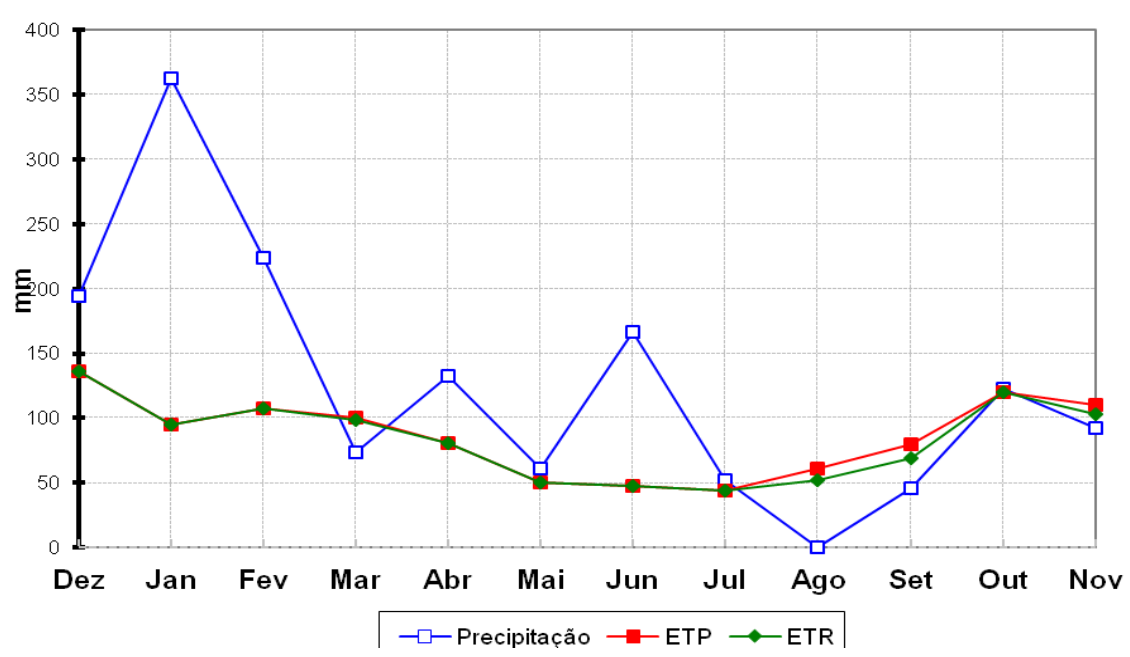

Figura 16. Gráfico do balanço hídrico para o período de dezembro 2011 a novembro 2012

O excedente hídrico foi de $520,40 \mathrm{~mm}$, o equivalente a $34,0 \%$ da precipitação do período.

Tabela 6. Valores do cálculo da recarga e evapotranspiração pelo método de Thornthwaite, janeiro 2013 a dezembro 2013.

\begin{tabular}{|c|c|c|c|c|c|c|c|c|c|c|c|c|}
\hline Mês & $\begin{array}{l}\mathrm{T} \\
\text { oC }\end{array}$ & $\begin{array}{l}P \\
\mathrm{~mm}\end{array}$ & $\begin{array}{l}\text { Núm. } \\
\text { horas }\end{array}$ & 1 & $\begin{array}{l}\text { ETP } \\
\text { Thornthwaite } \\
1948\end{array}$ & $\begin{array}{l}\text { P-ETP } \\
\mathrm{mm}\end{array}$ & NEG-AC & $\begin{array}{l}\text { ARM } \\
\mathrm{mm}\end{array}$ & $\begin{array}{l}\text { ALT } \\
\mathrm{mm}\end{array}$ & $\begin{array}{l}\text { ETR } \\
\mathrm{mm}\end{array}$ & $\begin{array}{l}\text { DEF } \\
\mathrm{mm}\end{array}$ & $\begin{array}{l}\text { EXC } \\
\mathrm{mm}\end{array}$ \\
\hline Jan & 22,8 & 256,2 & 13,3 & 9,9 & 109,00 & 147,2 & 0,0 & 200,00 & 0,00 & 109,0 & 0,0 & 147,2 \\
\hline Fev & 23,5 & 197,4 & 13,0 & 10,4 & 106,82 & 90,6 & 0,0 & 200,00 & 0,00 & 106,8 & 0,0 & 90,6 \\
\hline Mar & 23,0 & 124,6 & 12,4 & 10,1 & 103,76 & 20,8 & 0,0 & 200,00 & 0,00 & 103,8 & 0,0 & 20,8 \\
\hline$A b r$ & 20,6 & 142,6 & 11,8 & 8,5 & 72,77 & 69,8 & 0,0 & 200,00 & 0,00 & 72,8 & 0,0 & 69,8 \\
\hline Mai & 17,9 & 139,5 & 11,1 & 6,9 & 50,79 & 88,7 & 0,0 & 200,00 & 0,00 & 50,8 & 0,0 & 88,7 \\
\hline Jun & 16,5 & 81,9 & 10,7 & 6,1 & 38,83 & 43,1 & 0,0 & 200,00 & 0,00 & 38,8 & 0,0 & 43,1 \\
\hline Jul & 17,8 & 49,7 & 10,7 & 6,8 & 47,91 & 1,8 & 0,0 & 200,00 & 0,00 & 47,9 & 0,0 & 1,8 \\
\hline Ago & 20,4 & 4,3 & 11,0 & 8,4 & 68,68 & $-64,4$ & $-64,4$ & 144,95 & $-55,05$ & 59,3 & 9,3 & 0,0 \\
\hline Set & 22,0 & 42,1 & 11,6 & 9,4 & 84,08 & $-42,0$ & $-106,4$ & 117,51 & $-27,45$ & 69,5 & 14,5 & 0,0 \\
\hline Out & 23,7 & 121,6 & 12,3 & 10,5 & 109,88 & 11,7 & $-87,4$ & 129,23 & 11,72 & 109,9 & 0,0 & 0,0 \\
\hline Nov & 23,9 & 291,7 & 12,9 & 10,7 & 114,10 & 177,6 & 0,0 & 200,00 & 70,77 & 114,1 & 0,0 & 106,8 \\
\hline Dez & 24,5 & 155,4 & 13,3 & 11,1 & 129,14 & 26,3 & 0,0 & 200,00 & 0,00 & 129,1 & 0,0 & 26,3 \\
\hline TOTAIS & 256,6 & 1607,0 & 144,1 & 108,9 & 1035,77 & 571,2 & & 2192 & 0,00 & 1011,9 & 23,9 & 595,1 \\
\hline MÉDIAS & 21,4 & 133,9 & 12,0 & 9,1 & 86,31 & 47,6 & & 182,6 & & 84,3 & 2,0 & 49,6 \\
\hline
\end{tabular}

Nota: $\mathrm{P}=$ precipitação; $\mathrm{T}$ = temperatura; $\mathrm{N}$ = horas do dia; I = índice térmico; $\mathrm{ETP}=$ evapotranspiração potencial; $A R M=$ armazenamento; $D E F$ = déficit; $A L T$ = variação do armazenamento; $E X C$ = excedente. 


\section{Balanço Hídrico Normal Mensal 2013}

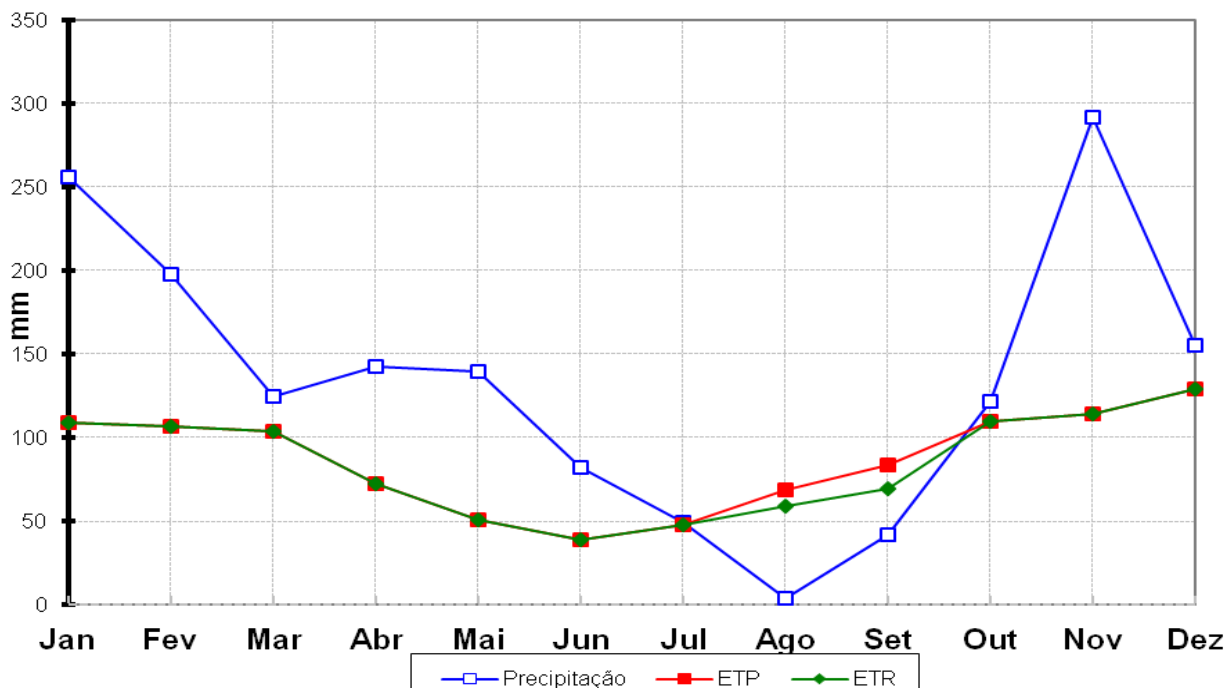

Figura 17. Gráfico do balanço hídrico para o período de janeiro 2013 a dezembro 2013

O excedente hídrico foi de $595,10 \mathrm{~mm}$, o equivalente a $37,0 \%$ da precipitação do período.

\subsubsection{Variação do nível de água}

A Formação Rio Claro é composta predominantemente de areia média (ZAINE, 1994; OLIVA, 2002; TAKIZAWA, 2012), entretanto, na área de estudo notou-se uma elevada quantidade de termos mais finos, como silte e argila, sobretudo em camadas mais profundas na zona saturada (Apêndice IV). Foi adotado o valor porosidade efetiva de Neto e Chang (2008) de Sy = 0,17.

O período considerado para o cálculo da estimativa de recarga iniciou-se no mês de novembro de 2011 até novembro de 2012. O mês de março foi considerado o início da recarga, pois apresentou o menor valor, adequado para as considerações do cálculo; e o mês de julho foi considerado o pico da recarga. Sendo assim, a variação $(\Delta \mathrm{h})$ pode ser calculada pela diferença entre o nível mínimo, obtida pela extrapolação da curva até da tendência à diminuição do nível de água para o ano (se este continuasse a cair - h0) e o pico de carga hidráulica (h1) registrados no mesmo poço, como na Figura 17. Dessa forma, foram calculados os $\Delta h$ dos poços $A, B, C, D, E$ e $F$, e aplicada a equação a seguir: 


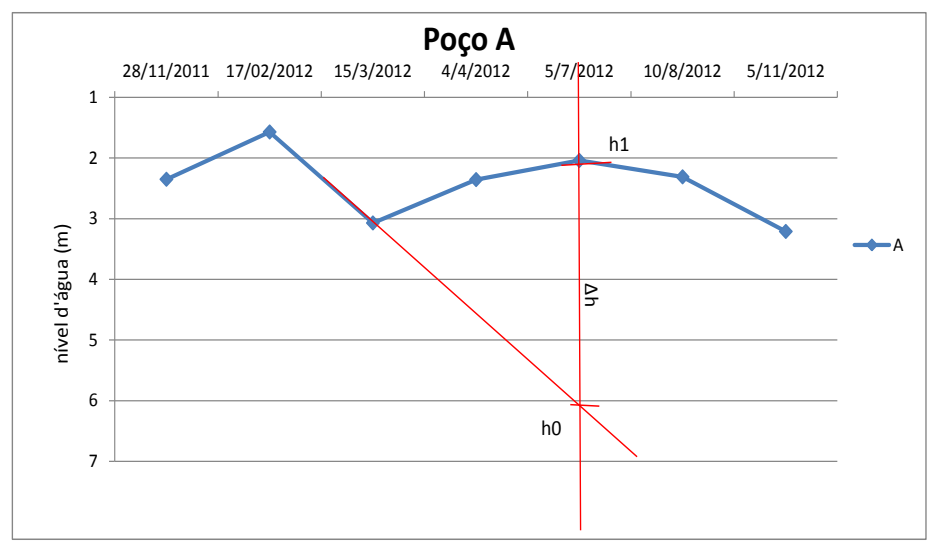

Figura 18. Gráfico para o cálculo de recarga do poço A utilizandose do método de variação de nível de água

O valor médio das recargas obtidas foi de $576,73 \mathrm{~mm} / \mathrm{ano}$, equivalente a $37,8 \%$ da precipitação do período.

\subsubsection{Aproximações darcynianas}

Para o cálculo da estimativa, foi considerado que a área da lagoa é a principal área de recarga, tanto em períodos secos como úmidos, e que o valor da espessura saturada (b) é igual a 30 metros, com base no trabalho de Zaine (1994). Considerou-se 350m como valor da seção transversal, largura da área perpendicular ao fluxo de água (área perpendicular ao fluxo = profundidade $x$ largura); e 350m como a distância entre a área de recarga e a área de descarga (L).

Com isso, calculou-se o gradiente hidráulico a partir da lâmina d'água para época úmida, março/2013 (620 m), e seca, agosto/2012 (618 m), subtraindo-se da cota da zona de descarga (nascente 1), correspondente a 614m. Tendo o valor da condutividade hidráulica obtida, calculou-se a recarga (Tabela 17).

A área considerada para a ocorrência da Recarga foi a superfície do lago, cujo raio é aproximadamente igual à $200 \mathrm{~m}$. 
Tabela 8. Cálculo da estimativa de recarga pelo método de Aproximação Darcyniana

\begin{tabular}{|l|l|l|l|l|l|l|l|l|}
\hline \multicolumn{2}{|l|}{ Período Seco } \\
\hline $\begin{array}{l}\text { K (m/s) } \\
\text { i }\end{array}$ & $\begin{array}{l}\text { b } \\
(\mathrm{m})\end{array}$ & $\begin{array}{l}\mathrm{L} \\
(\mathrm{m})\end{array}$ & $\mathrm{Q}\left(\mathrm{m}^{3} / \mathrm{s}\right)$ & $\mathrm{Q}\left(\mathrm{m}^{3} / \mathrm{ano}\right)$ & $\mathrm{A}\left(\mathrm{m}^{2}\right)$ & $\begin{array}{l}\text { Recarga } \\
(\mathrm{m} / \text { ano })\end{array}$ & $\begin{array}{l}\text { Recarga } \\
(\mathrm{mm} / \mathrm{ano})\end{array}$ \\
\hline $1,96.10^{-5}$ & 0,01143 & 30 & 350 & 0,002352 & $74.172,67$ & $125.663,71$ & 0,59032 & 590,32 \\
\hline
\end{tabular}

Os resultados são apresentados no quadro a seguir:

Tabela 9. Resultado do cálculo de estimativa de recarga com três técnicas diferentes

\begin{tabular}{|l|c|c|}
\hline \multicolumn{1}{|c|}{ Métodos } & Recarga (mm/ano) & \% Precipitação \\
\hline Flutuação dos níveis potenciométricos - 2012 & 576,73 & 37,8 \\
\hline Balanço hídrico - Thornthwaite - 2012 & 520,40 & 34,1 \\
\hline Balanço hídrico - Thornthwaite - 2013 & 595,10 & 39,0 \\
\hline Aproximação Darcyniana - seco, ago/2012 & 590,32 & 38,7 \\
\hline Aproximação Darcyniana - úmido, mar/2013 & 885,22 & 58,0 \\
\hline
\end{tabular}

\subsubsection{Isótopos estáveis}

A reta meteórica local foi estabelecida a partir dos dados do GNIP (IAEA, 2014) coletados na cidade de Piracicaba (SP) e tem a formulação: $\delta D=8,13 \delta^{18} \mathrm{O}+13,8$, muito próxima à reta meteórica global $\delta \mathrm{D}=8,17( \pm 0,07) \delta^{18} \mathrm{O}+11,27( \pm 0,65)($ Clark e Fritz $(1997))$ ou à reta estabelecida por Stradioto e Chang (2010) para a cidade de Rio Claro, $\delta D=8,7$ $\delta^{18} \mathrm{O}+13,9$. Os valores relativos à estação chuvosa de outubro a março são mais leves que a estação seca, entre abril e setembro, indicando claramente o efeito de quantidade (CLARK e FRITZ, 1997). 


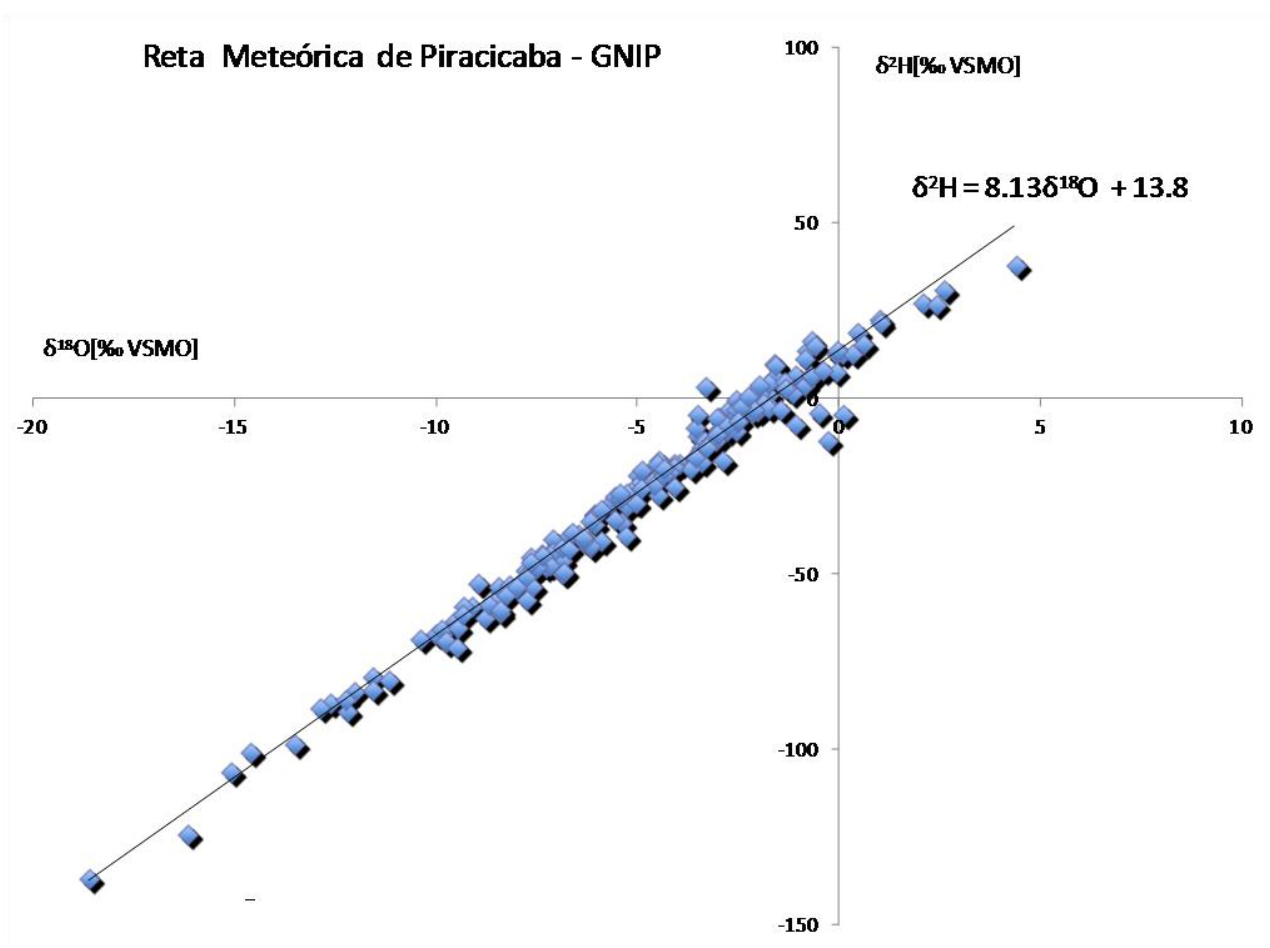

Figura 19. Relação entre 180 e $2 \mathrm{H}$ (D) dos eventos de chuvas em Piracicaba e a reta meteórica local no período entre 1989 e 1998 (dados de IAEA - International Atomic Energy Agency, http://www-naweb.iaea.org/napc/ ih/IHS_resources_isohis.html).

Ao analisar os dados isotópicos das águas subterrâneas, nota-se que estas se alinham sob a reta meteórica local (Figura 19), sugerindo que a água da lagoa, que recarrega o aquífero, é resultado da evaporação desse corpo de água superficial. As águas subterrâneas dos diferentes poços de monitoramento são resultado da mescla de águas da recarga direta da chuva (que possui uma assinatura isotópica próxima a $\delta^{18} \mathrm{O}=-9$ por mil) (poços L, E, D e B), que se infiltram e recarregam o aquífero, e as águas evaporadas da lagoa $\left(\delta^{18} O=2,3\right)$. Esses resultados corroboram com a ideia de que a lagoa funciona como uma área de recarga, e ao longo do fluxo entre a lagoa e a descarga, que ocorre junto à nascente ou às drenagens a oeste da lagoa, o aquífero recebe recarga através do excedente hídrico das chuvas que caem na área (Figura 19).

Assim, a lagoa possui as águas mais enriquecidas, resultado da evaporação $\left(\delta^{18} O=2,3\right.$ e $\left.\delta^{2} H=4,1\right)$, e essas águas são um dos "end members" que recarregam o aquífero. O outro, provavelmente é uma água com assinatura isotópica $\delta^{18} \mathrm{O} \approx-9$ por mil e $\delta \mathrm{D} \approx-60$ por mil, que provavelmente está associada à recarga na área pela chuva, e que é isotopicamente próxima aos poços L, E, D e B (Grupo 1, Figura 20). 


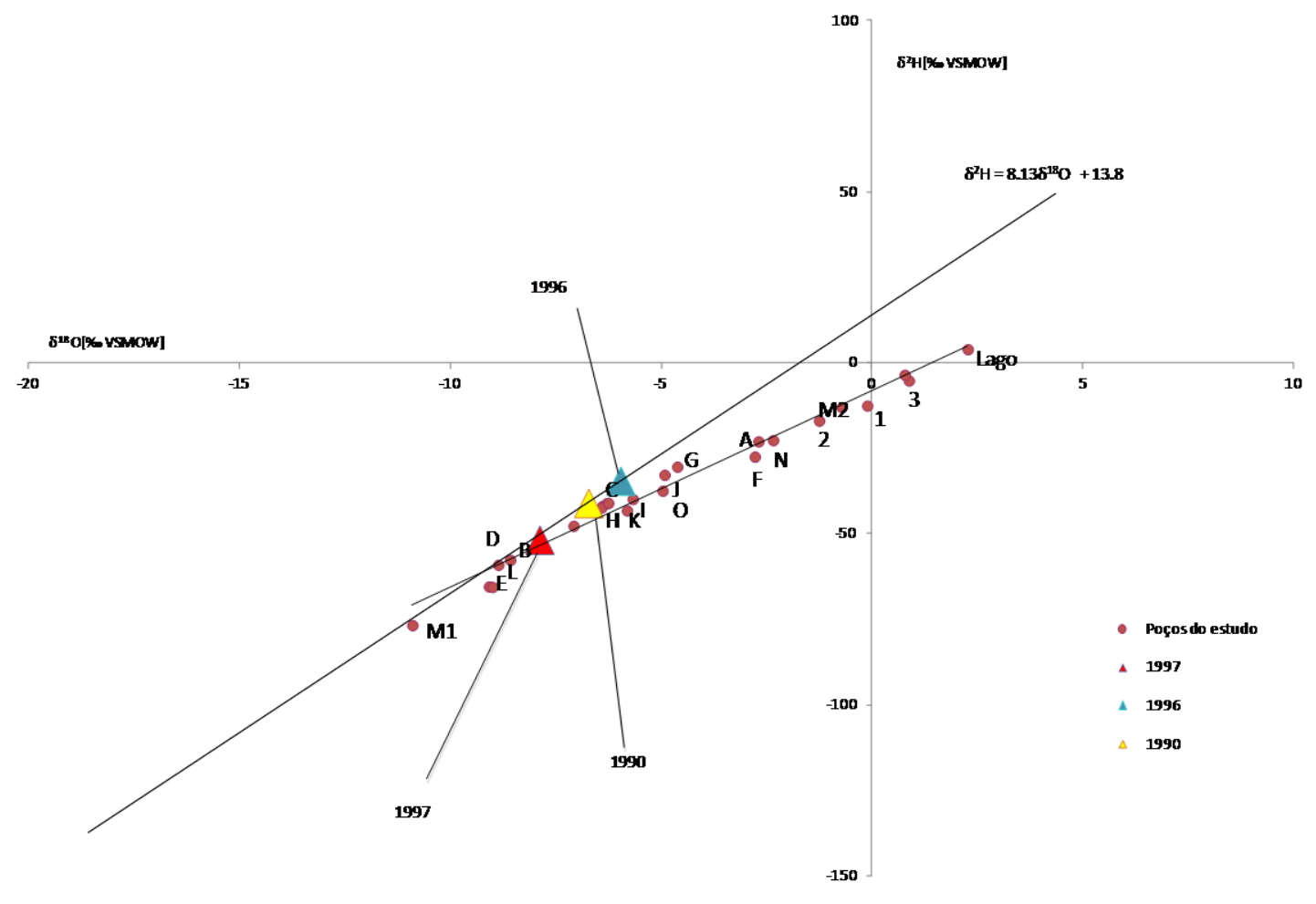

Figura 20. Reta meteórica local, alinhamento das águas subterrâneas locais e água da lagoa, mostrando que esta é o resultado da evaporação de águas da chuva e a média ponderada com a chuva, a partir dos dados da chuva.

O poço M2 tem valor próximo às águas da lagoa, pois foi perfurado com águas da lagoa, contaminando o mesmo. Já o poço M1 não apresenta uma assinatura compatível com o modelo, pois tem águas mais negativas das esperadas para a água de recarga do aquífero. Devido à sua posição geográfica, esta poderia estar recebendo alguma água mais do leste, mas não há indícios desse fluxo. Uma nova campanha poderia mostrar se há algum erro na análise dessas águas.

A Figura 21 mostra que a distribuição das assinaturas isotópicas das águas subterrâneas guarda uma forte relação com a distância da lagoa, sugerindo que quanto mais distante desta, maior é a influência das águas infiltradas pela chuva no solo. Esse efeito ocorre porque os novos tubos de fluxos gerados pelas infiltrações das águas de chuva acabam "empurrando" os tubos de fluxos de águas provenientes da lagoa mais para baixo, e como os poços de monitoramento têm apenas uma seção de filtro, não são capazes de detectar esse fenômeno de forma estratificada. Em um sistema transiente, deve-se 
considerar que as águas da lagoa também se mesclam às águas de recarga das chuvas ao longo do percurso até a área de descarga (nascente 1 ).

A Figura 21 mostra também que os poços do Grupo 2 encontram-se invertidos em relação aos poços do Grupo 3 no mapa da Figura 20. Essa distribuição pode indicar que os poços do Grupo 3 recebem menos água da chuva que da lagoa, comparativamente ao Grupo 2. Uma possível explicação para esse fenômeno estaria associada à maior evapotranspiração e interação dos eucaliptos (onde estão os poços do Grupo 3) do que nas outras áreas. Assim, se toda a área fosse homogeneamente ocupada, essa inversão não existiria.

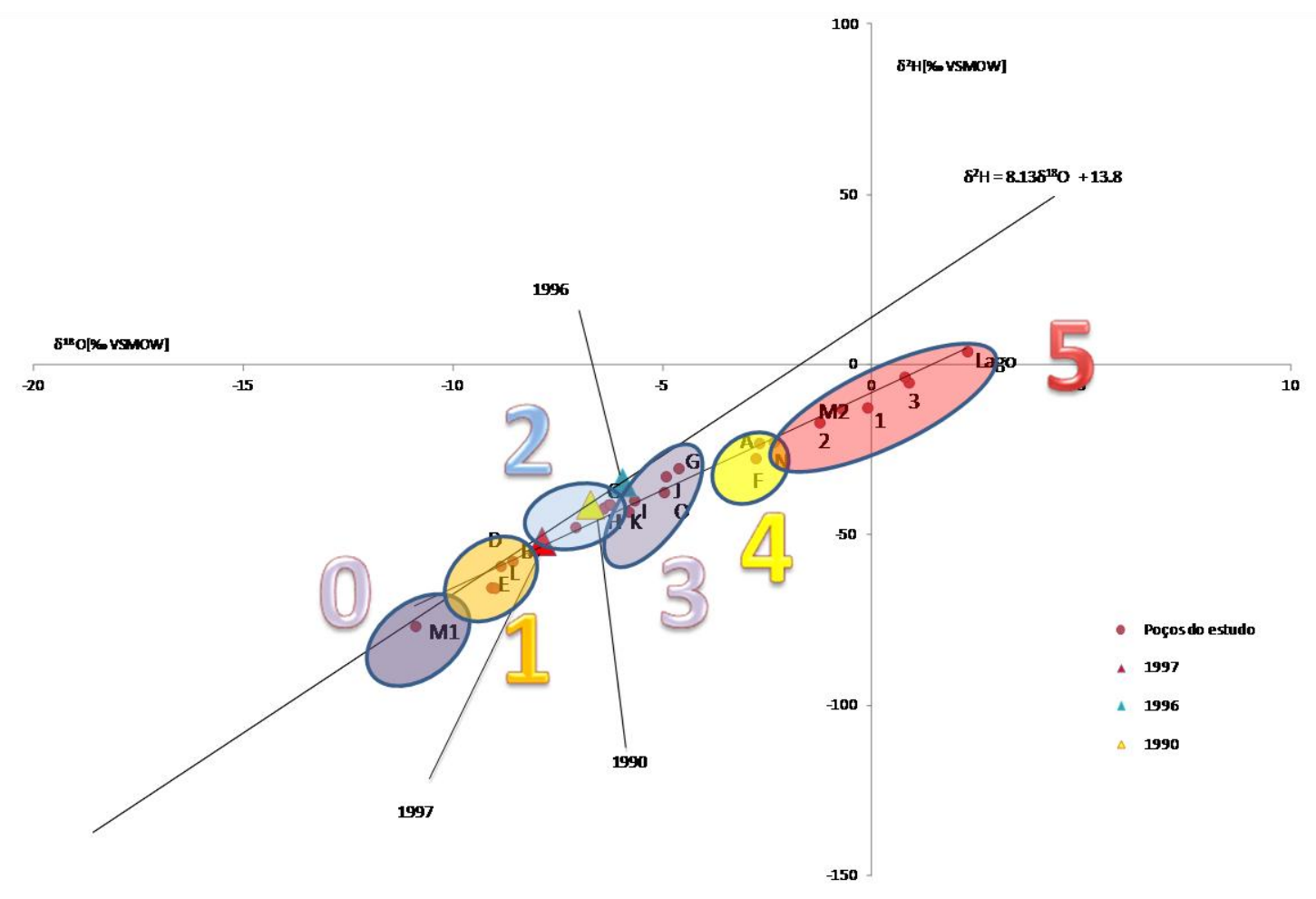

Figura 21. Valores das razões isotópicas na reta de evaporação dos poços de monitoramento, segundo a distância da lagoa (ver mapa associado da Figura 21) 


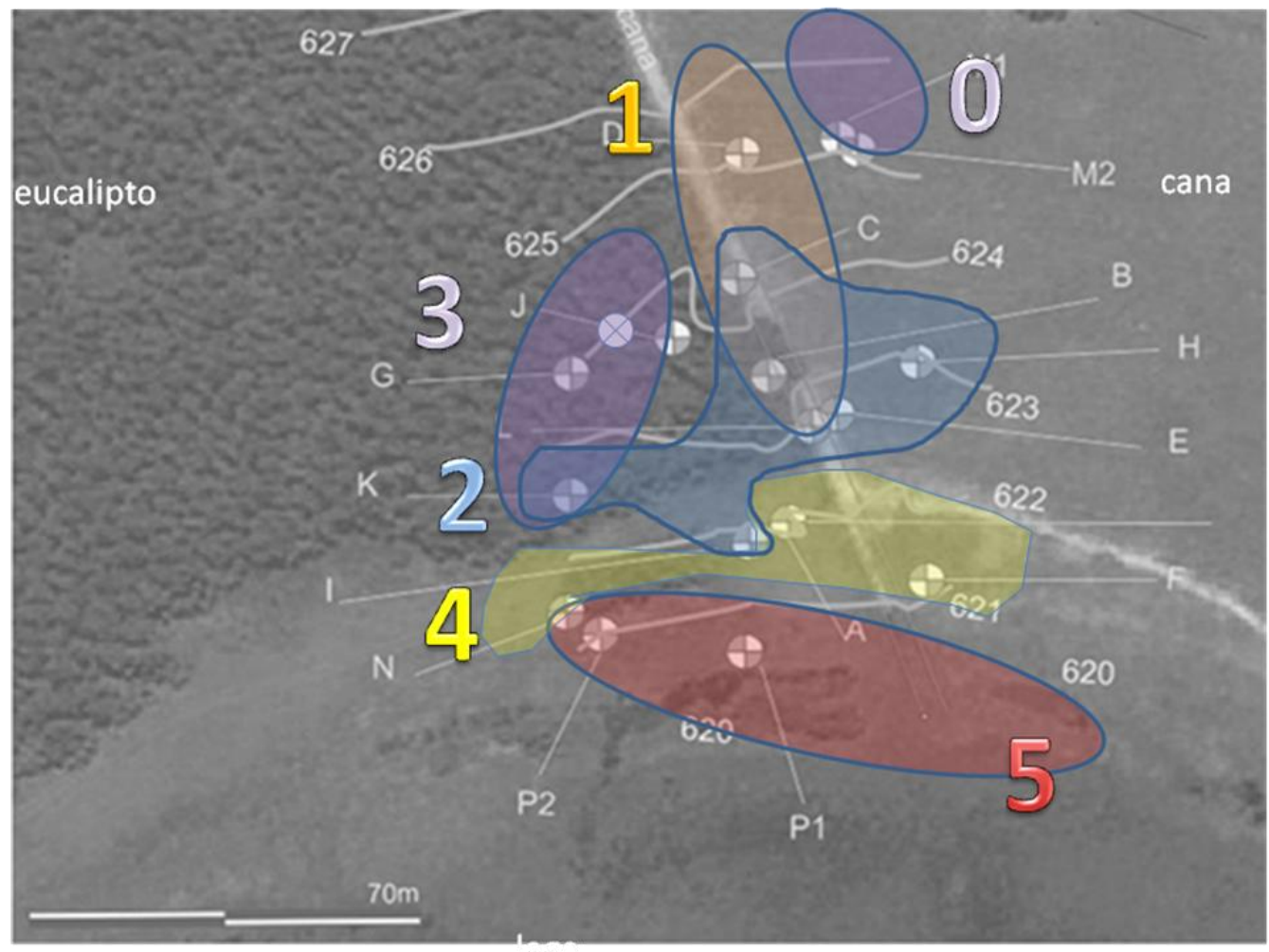

Figura 22. Agrupamento dos poços segundo a assinatura isotópica de suas águas (ver Figura 20)

\subsection{Geofísica}

Os resultados dos ensaios geofísicos apoiaram a descrição hidrogeológica da área e foram apresentados no Trabalho de Conclusão de curso de Luís Adensohn (ADENSOHN, 2013) e serviram para avaliar a umidade do solo na região, uma vez que esta está intimamente relacionada à recarga e ao fluxo das águas subterrâneas.

Realizaram-se duas campanhas, uma em julho de 2013 e outra um mês após o corte da plantação de eucaliptos, ocorrido em agosto de 2013.

Com a colheita de eucalipto, esperava-se que a campanha realizada em setembro de 2013 detectasse valores menores de resistividade na superfície a partir do suposto aumento da umidade do solo devido ao corte da plantação de eucalipto, incremento, em certa medida, a recarga do aquífero. No entanto, observou-se que a resistividade aumentou globalmente em todas as linhas leste-oeste (1, 2 e 3), especialmente nas áreas de plantio de eucalipto, obedecendo a um padrão de resistividade que varia com a espessura da zona saturada, ou seja, a resistividade diminui à medida que se aproxima da lagoa. 
Sabendo que a única fonte de recarga primária da área é a chuva, a baixa pluviosidade no período entre as campanhas foi insuficiente para modificar substancialmente as condições da umidade do solo, o que fez com que as raízes absorvessem água exclusivamente dessa reserva.

Um exemplo dos resultados para as linhas de caminhamento elétrico leste-oeste (eucalipto - cana-de-açúcar) é mostrado nas Figuras 23 e 24.

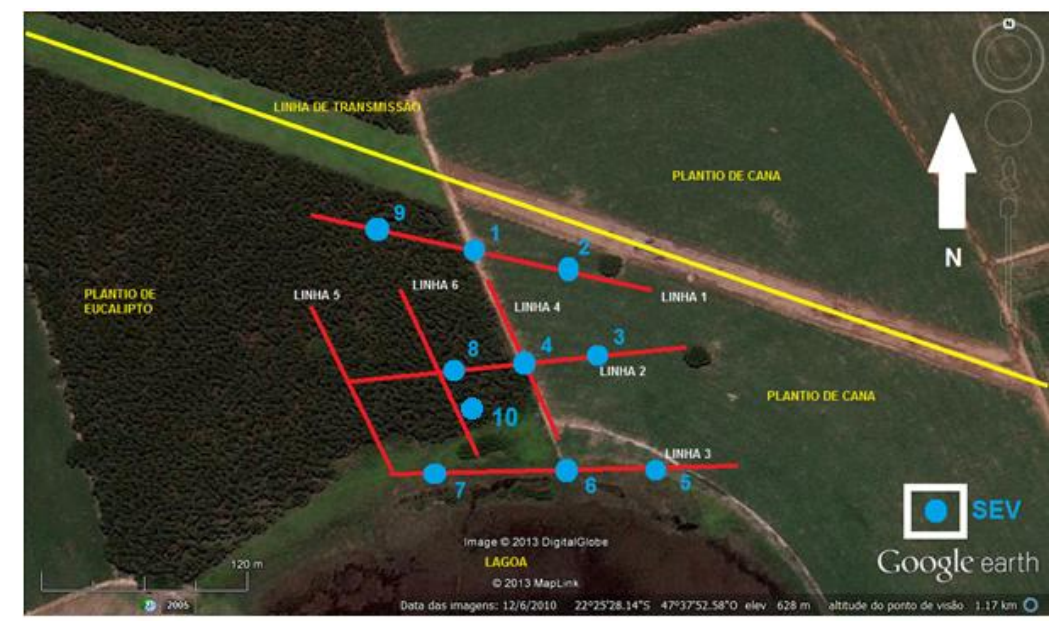

Figura 23. Localização dos levantamentos geofísicos (ADENSOHN, 2013)

\section{Eucalipto}

Cana

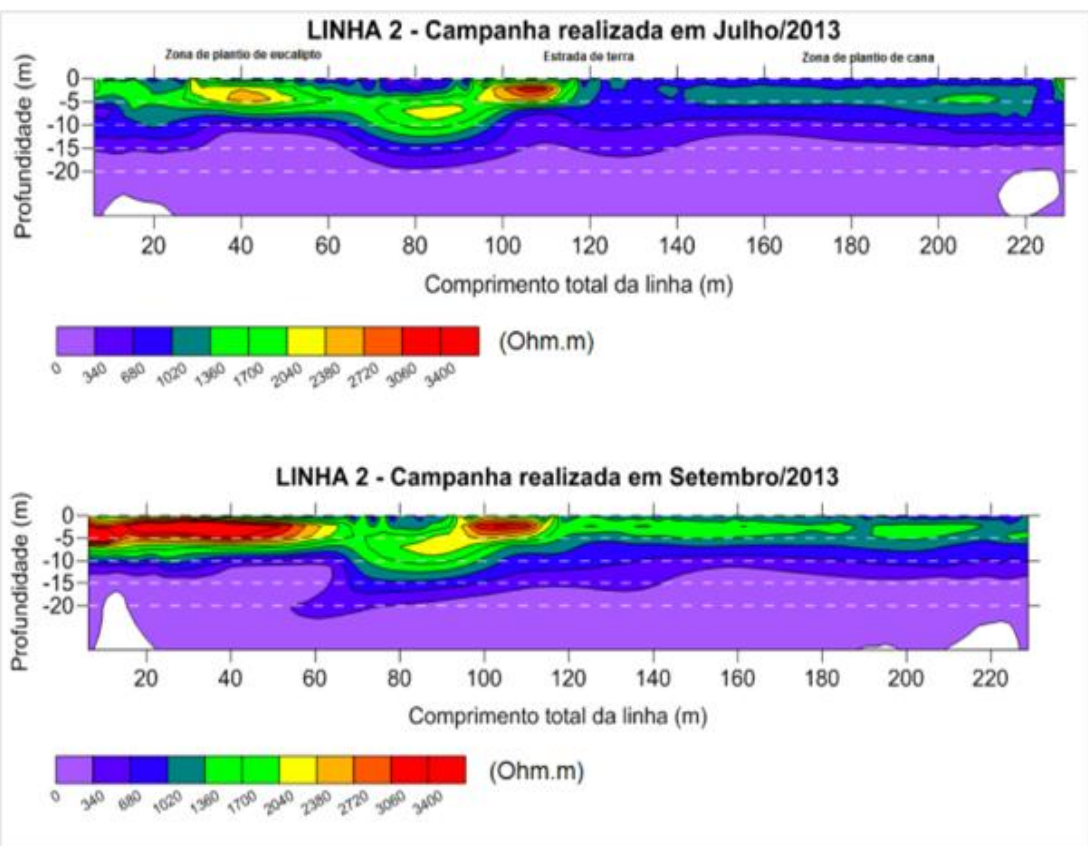

Figura 24. Campanhas para a linha L2 (ADENSOHN, 2013) 
Todas as linhas norte-sul (linhas 4, 5 e 6) apresentaram o mesmo perfil, com maior resistividade a montante (norte), ou maior teor de umidade a jusante (sul). A Linha 4 (Figura 22) é um exemplo dessa diferença de resistividade entre norte e sul da área, além disso, também pode-se observar diferença entre julho e setembro, quando a tendência é a mesma, porém, intensificada.
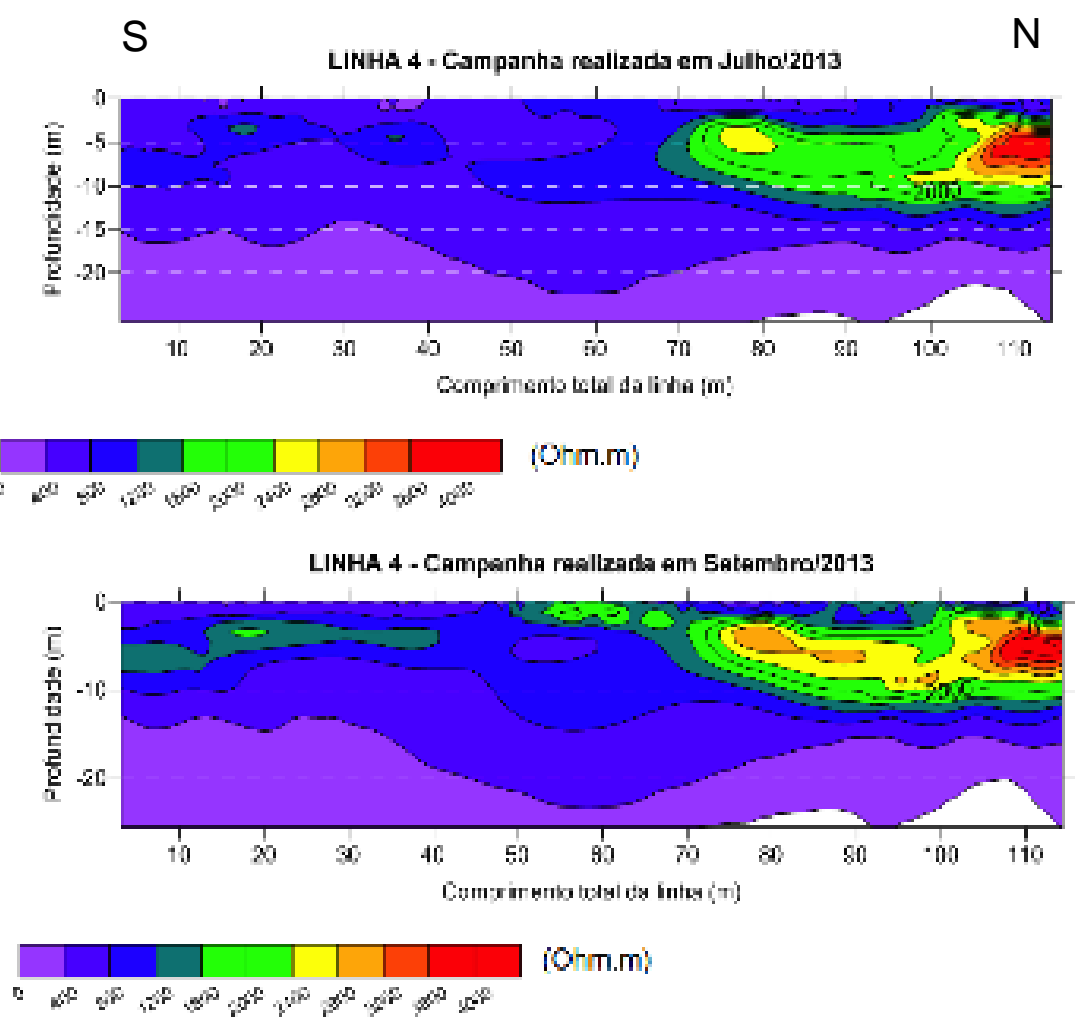

Figura 25. Campanhas para a linha L4 (ADENSOHN, 2013)

As SEVs indicaram, com boa precisão, o nível de água e, posteriormente, foram feitas ao longo das linhas, caminhamento elétrico para confirmar esses resultados.

A campanha de aquisição das SEVs foi realizada no final de agosto, e, em geral, os dados apontam três estratos geoelétricos principais, exceto as SEVs 6 e 8 que apresentam um quarto estrato. A Tabela 18 mostra a relação das SEVs com as profundidades dos estratos geoelétricos: 
Tabela 10. Relação das profundidades dos estratos geoelétricos em cada SEV realizada. Nível de água aparente entre camada 2 e 3 (ADENSOHN, 2013)

\begin{tabular}{|l|l|l|l|l|}
\hline SEV & Camada $\mathbf{1}(\mathbf{m})$ & Camada 2 (m) & Camada 3 (m) & Camada 4 (m) \\
\hline $\mathbf{1}$ & $0-1.33$ & $1.33-4.57$ & $4.57-24.9$ & - \\
\hline $\mathbf{2}$ & $0-1.00$ & $1.00-5.24$ & $5.24-19.1$ & - \\
\hline $\mathbf{3}$ & $0-0.534$ & $0.534-2.75$ & $2.75-13.5$ & - \\
\hline $\mathbf{4}$ & $0-1.69$ & $1.69-4.81$ & $4.81-19.2$ & - \\
\hline $\mathbf{5}$ & $0-1.21$ & $1.21-4.48$ & $4.48-10.9$ & - \\
\hline $\mathbf{6}$ & $0-0.5$ & $0.5-1.21$ & $1.21-7.18$ & $7.18-$ \\
\hline $\mathbf{7}$ & $0-0.729$ & $0.729-2.5$ & $2.5-6.08$ & - \\
\hline $\mathbf{8}$ & $0-2.61$ & $2.61-3.76$ & $3.76-13.2$ & $13.2-$ \\
\hline $\mathbf{9}$ & $0-2.26$ & $2.26-5.98$ & $5.98-16.9$ & - \\
\hline $\mathbf{1 0}$ & $0-3.57$ & $3.57-5.24$ & $5.24-11.1$ & - \\
\hline
\end{tabular}

A camada 1 apresentou espessura média de 1,54 metros de profundidade, com mínimo de 0,5 e máximo de 3,57 metros de profundidade, já próxima à lagoa, podendo ser interpretada como solo e primeiros níveis de areia.

A base da camada 2 apresentou profundidade média de 4,05 metros e indica o provável nível de água da região variando de 1,21 metros próxima à lagoa até 6,00 metros nas porções mais ao norte da área.

A SEV 10 foi realizada ao lado do poço de monitoramento "O" e apresenta o provável nível de água em 5,24 metros. Junto com a aquisição geofísica, foi realizada a medição do nível de água nos poços de monitoramento e o "O" apresentou valor em torno de 6,00 metros.

A camada 3 de profundidade média de 14,20 metros, variando de 7,18 metros próxima à lagoa e 24,9 metros nas porções mais ao norte da área. Apresenta valores menores de resistividade devido ao material que compõe a geologia local, e também por já fazer parte da zona saturada. 


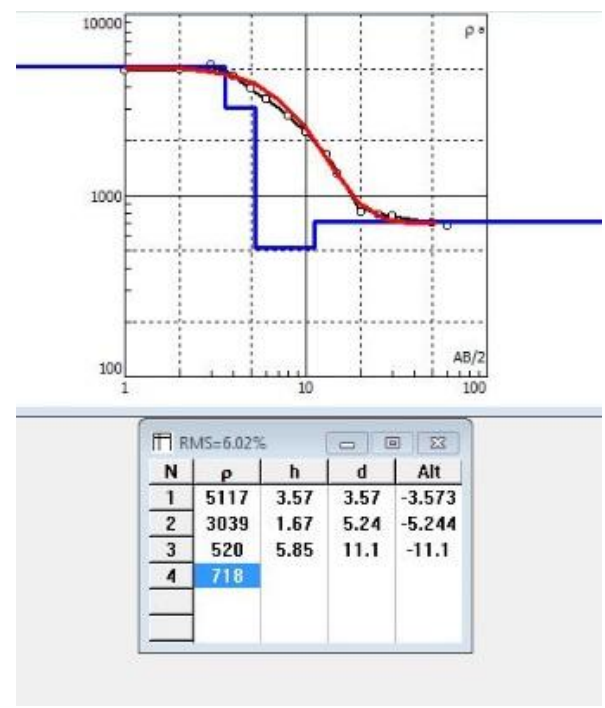

Figura 26. Curva da SEV 10, ao lado do poço de monitoramento "O" e tabela de resultados (ADENSOHN, 2013)

Os dados e o mapa confeccionado de SP com as curvas de isovalores em milivolts (mV) indicam que a direção de fluxo preferencial da região é de sudeste para noroeste (SE/NW). O levantamento SP (Figura 26) indica que, nesse sistema aquífero, a lagoa é influente na recarga do aquífero, como mostram os mapas potenciométrico a partir dos poços de monitoramento nos últimos dois anos (Figura 14).

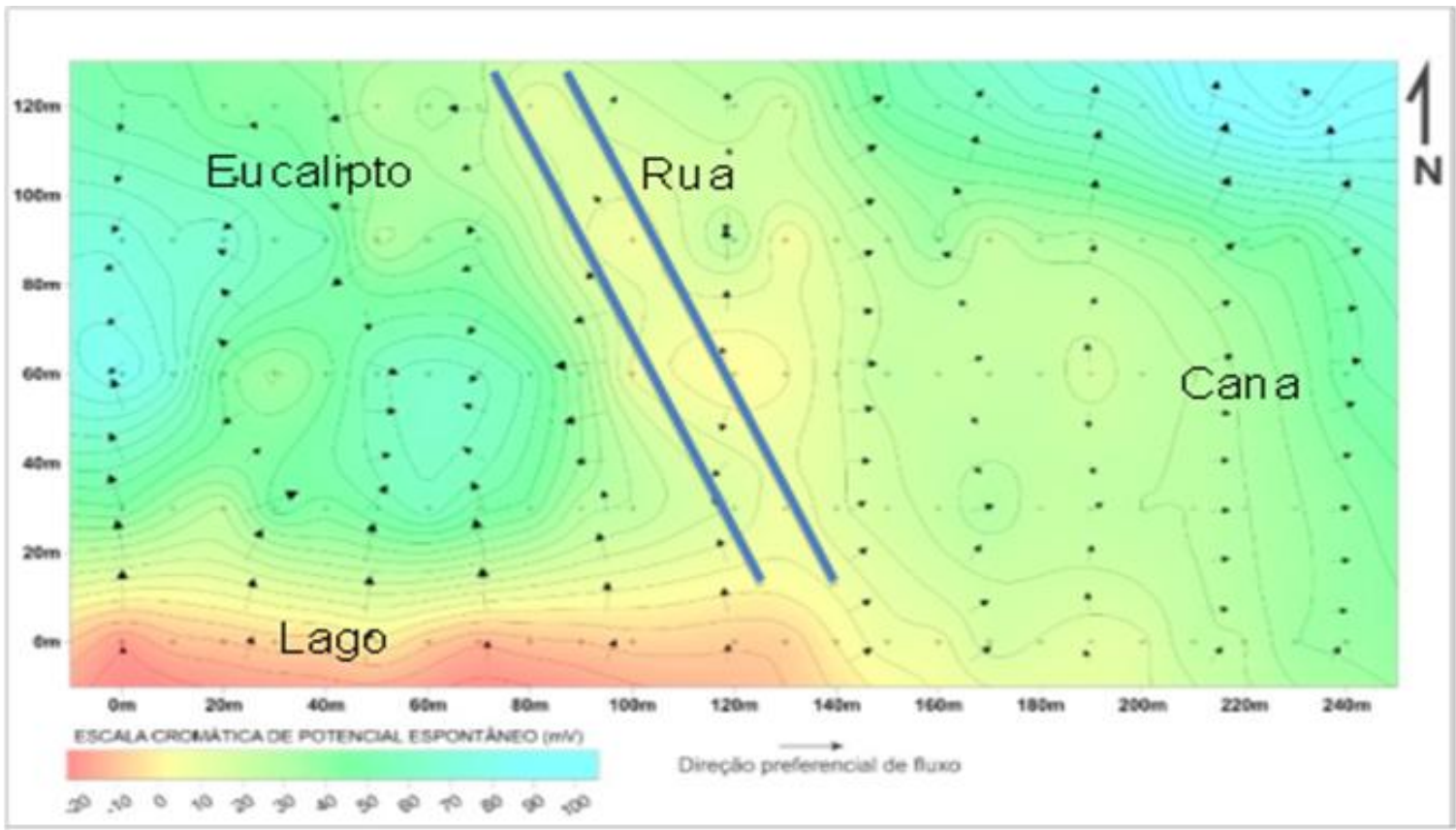

Figura 27. Curvas de isovalores de milivolts $(\mathrm{mV})$ referentes aos dados do levantamento do Potencial Espontâneo (SP) com interpolação das direções de fluxo subterrâneo (ADENSOHN, 2013). 


\subsection{Hidroquímica da área de estudo}

A área de estudo caracteriza-se por ter naturalmente águas de baixa salinidade (CE $27 \mu \mathrm{S} / \mathrm{cm}$ ), pH ligeiramente ácido (5-6) e composição bicarbonatada cálcica e magnesiana. Essa composição está de acordo com o observado na região em trabalhos anteriores (DAEE, 1981; OLIVA, 2002; STRADIOTO e CHANG, 2010), que atribuem essas características à baixa complexidade mineralógica dos sedimentos, aliada à rápida circulação das águas (rápido tempo de trânsito), em um ambiente oxidante e com presença de $\mathrm{CO}_{2}$ atmosférico.

A partir do diagrama de Piper (Figura 27), em uma análise mais pormenorizada, é possível ver que as águas dos poços de monitoramento distribuem-se em três grupos, segundo a ocupação do terreno: cana-de-açúcar, eucalipto e proximidade da lagoa:

a) cana-de-açúcar: as águas dos poços são nitidamente mais cálcicas (geralmente $>10$ $\mathrm{mg} / \mathrm{L}$ ), que as outras águas (b e c) com forte correlação com a presença de nitrato (6,16 a 272,64 mg/L, na forma de nitrato), exceto o poço $M 1(<0,03 \mathrm{mg} / \mathrm{L})$. O ânion preponderante varia de bicarbonatado a cloretado. Essa característica pode ser atribuída à calagem do solo (com calcário ou cálcio dolomítico que explica a presença de magnésio), prática bastante comum na área devido à pobreza do solo arenoso e à aplicação de fertilizantes nitrogenados. Os poços E e L chamam a atenção pelas altas concentrações de nitrato (respectivamente até $120 \mathrm{mg} / \mathrm{L}$ e 272,64 mg/L), associadas a elevadas concentrações de cálcio e magnésio;

b) eucalipto: as águas dos poços são as menos cálcicas e não apresentam nitrato $(<1,41$ $\mathrm{mg} / \mathrm{L}$, exceto poço J com até $7,23 \mathrm{mg} / \mathrm{L}$ ), tendo como ânion preponderante o bicarbonato. As baixas concentrações de nitrato são atribuídas à pequena aplicação de fertilizantes associada ao consumo dessas árvores. A anomalia encontrada no poço J pode ser atribuída aos animais de grande porte (vacas e cavalos) que pastavam na área e chegaram a atingir particularmente esse poço;

c) lagoa: os poços junto às margens da lagoa apresentam também uma composição bicarbonatada cálcica, com níveis baixos de nitrato (geralmente $<1 \mathrm{mg} / \mathrm{L}$, até 5,66 $\mathrm{mg} / \mathrm{L}$ ) e teores variados de cálcio. É bom lembrar que embora a lagoa represente um 
ponto potenciometricamente mais elevado que o aquífero da região, ela se encontra topograficamente mais baixa e recebe também todo o solo vindo da erosão das culturas circundantes, sobretudo cultura da cana-de-açúcar, trazendo consigo potenciais nutrientes à lagoa.

A lagoa é uma das áreas de recarga do aquífero e as águas fluem desta em direção à plantação de eucalipto e cana-de-açúcar. Na direção desse fluxo, essas águas ganham sódio proporcionalmente à perda do cálcio, como observado na área dos eucaliptos. Já no caso das águas sob a cana-de-açúcar, isso não é observado, pois a influência da calagem e da fertilização acaba por mascará-las.

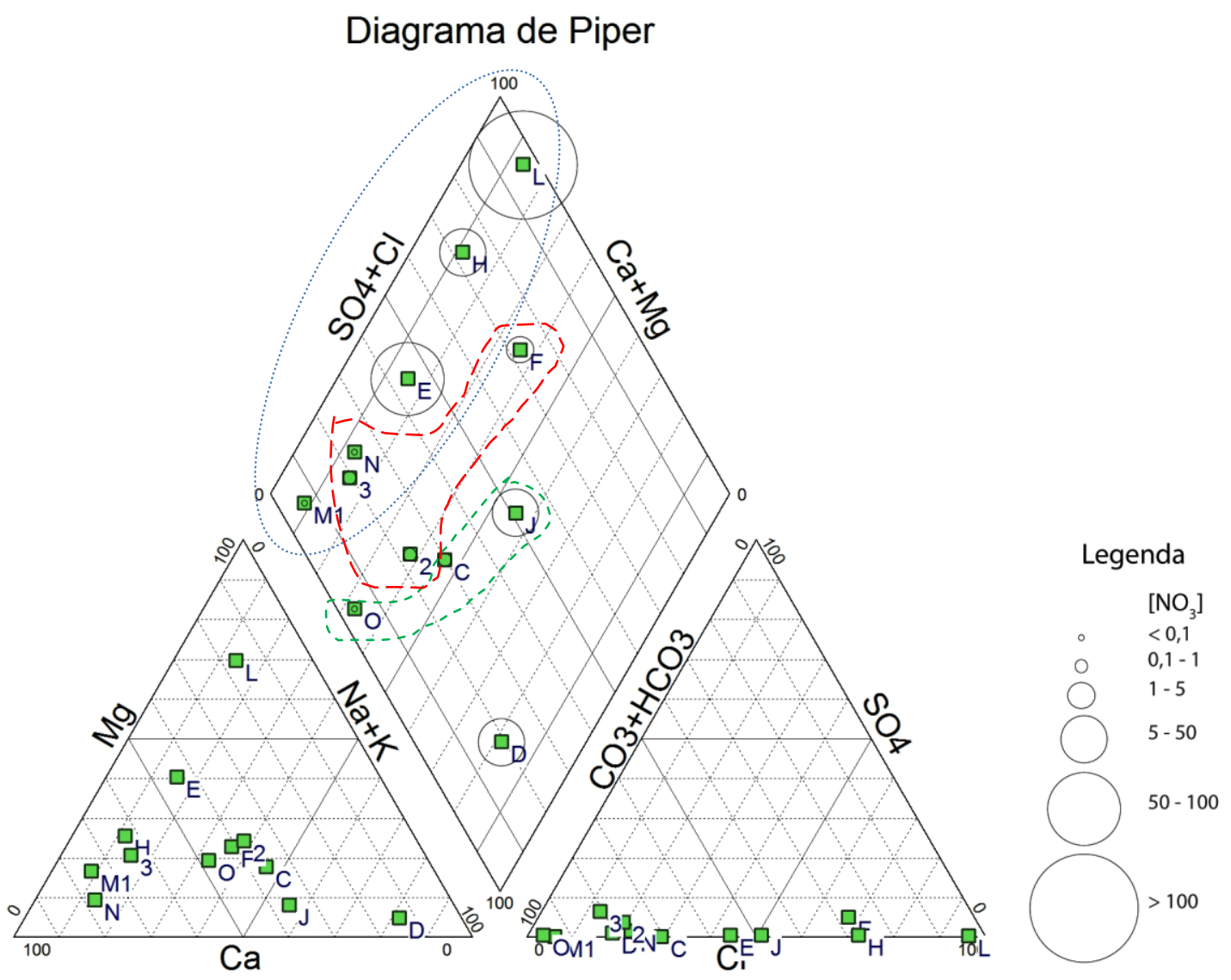

Figura 28. Diagrama de Piper correspondente ao tipo de hidroquímico da Formação Rio Claro em poços de monitoramento. Nota: tracejado azul: cana-de-açúcar; vermelho: lagoa; verde: eucalipto. 


\subsection{Modelo conceitual}

O Aquífero Rio Claro na porção rural apresenta espessura não maior que 30 metros e encontra-se sobre a Formação Corumbataí na área de estudo. Trata-se de um aquífero raso, livre e hidraulicamente ligado à lagoa em cotas entre 618 e 620 m.s.n.m., dependendo do regime de chuvas, e às nascentes, em topografias abaixo de 614 m.s.n.m.

A presença de lagoas é uma característica peculiar dessa formação, que permite que a água se acumule sobre lentes de argila ligadas a eventos de depósitos fluviais argilosos do passado. Essa morfologia permitiu que, atualmente, essas lagoas atuem como zona de descargas associadas às drenagens do local, ao mesmo tempo em que interagem com a água subterrânea de modo influente em épocas úmidas e, algumas vezes, afluente em épocas de estiagem. Na área de estudo, a lagoa (quando com água) é sempre influente ao aquífero e não se encontra suspensa em relação ao mesmo, mas sim diretamente conectada a ele.

Foi possível entender essa característica pelos dados dos ensaios geofísicos, isotópicos e hidráulicos que mostraram o sentido do fluxo da água subterrânea, sempre, independentemente do regime de chuvas, da lagoa para as drenagens próximas. Por outro lado, apesar de a hidroquímica ter apresentado resultados com variações muito grandes, devido principalmente à contaminação das águas subterrâneas associadas à cultura da canade-açúcar, não se observam evoluções químicas importantes nas águas jovens, de rápida circulação, desde a lagoa até a área de descarga.

A precipitação anual calculada, para o período de 2012 e 2013, período de estudo, foi de $1525 \mathrm{~mm}$ e de $1607 \mathrm{~mm}$, respectivamente, apresentando uma distribuição heterogênea, com maiores precipitações no mês de janeiro (362,4 e 256,2mm), contrastando com o mês de agosto $(0,0$ e 4,3 mm). Os valores acumulados entre abril e setembro foram iguais a 456,8 e $460,1 \mathrm{~mm}$, e entre outubro e março iguais a 1163,6 e $1146,9 \mathrm{~mm}$.

A taxa de recarga foi estimada por três metodologias diferentes, chegando aos valores de $885 \mathrm{~mm}$ (úmido) e $590 \mathrm{~mm}$ (seco) com aproximações darcynianas; $520 \mathrm{~mm}$ (ano de 2012) e 595 mm (ano de 2013) com balanço hídrico; e 576 mm com flutuação de nível de 
água. Os dois últimos métodos apresentam melhor aproximação da realidade, entretanto, todos os três mostraram valores altos, entre 520 e 590 mm/a, mas compatíveis entre si.

O modelo conceitual da relação lagoa-aquífero é apresentado nas figuras 28 e 29, que são as seções hidrogeológicas que melhor representam os níveis potenciométricos do aquífero, as relações com a lagoa e as áreas de descarga, junto à drenagem e à nascente. Esse modelo é fortemente apoiado pela distribuição das assinaturas isotópicas das águas da lagoa (evaporadas) em um extremo e das águas de recarga natural pela chuva no outro extremo, uma vez que, à medida que se distanciam da lagoa, observa-se uma sequência de mescla entre as duas águas.

A Figura 28 apresenta o fluxo da água subterrânea em direção ao norte, para áreas de cotas topográficas mais altas que a lagoa. Os níveis na época do aquífero mais elevado e mais baixo são igualmente representados. A outra seção (Figura 29) mostra o fluxo da água dirigindo-se às áreas de descarga a oeste, junto às drenagens superficiais. A carga hidráulica do lago apresenta-se sempre acima da carga hidráulica da nascente tanto em épocas úmidas quanto nas estiagens, de acordo com os mapas potenciométricos das Figuras 14.

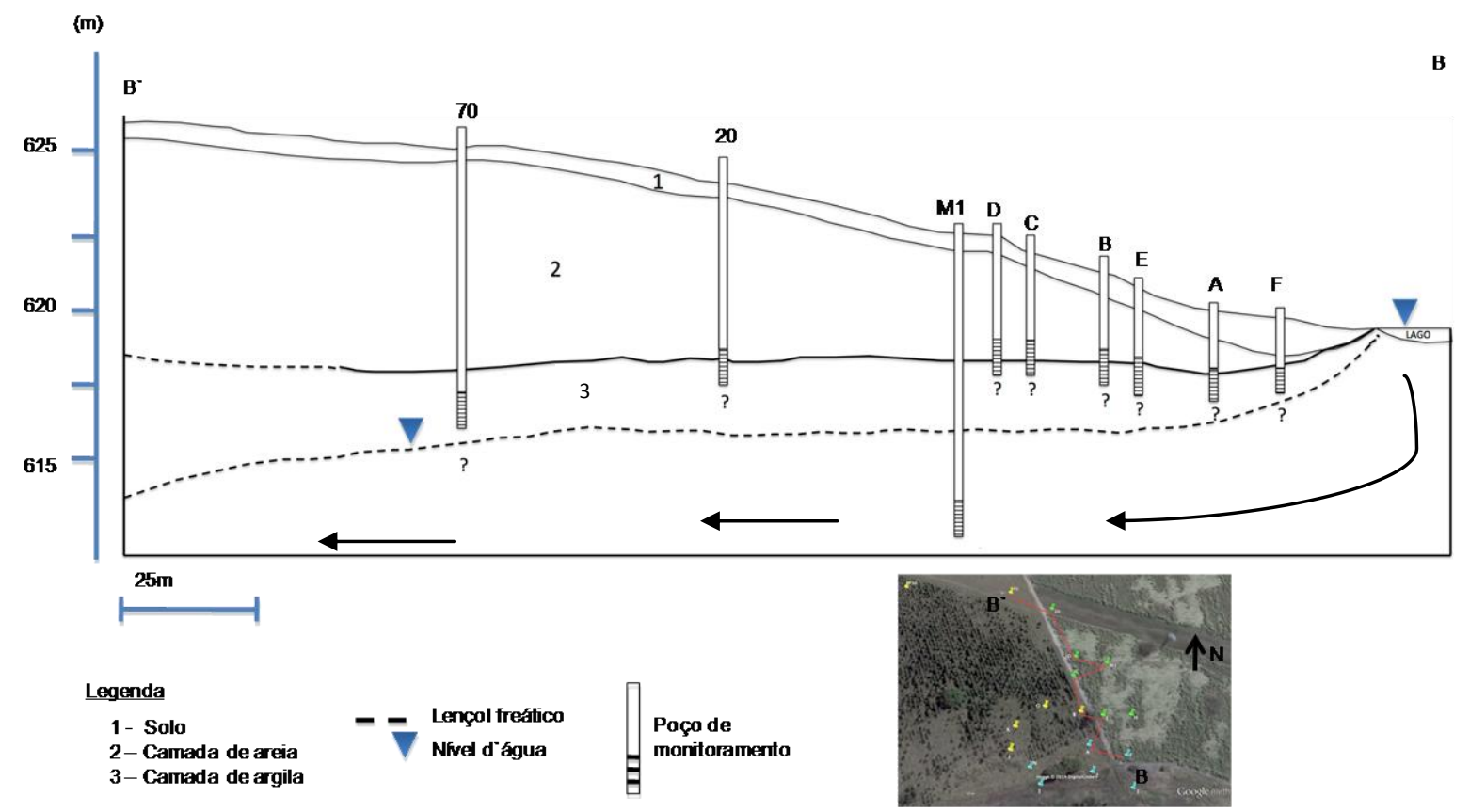

Figura 29. Modelo conceitual da área de estudos - Corte B-B' - nível de água em período de estiagem. 


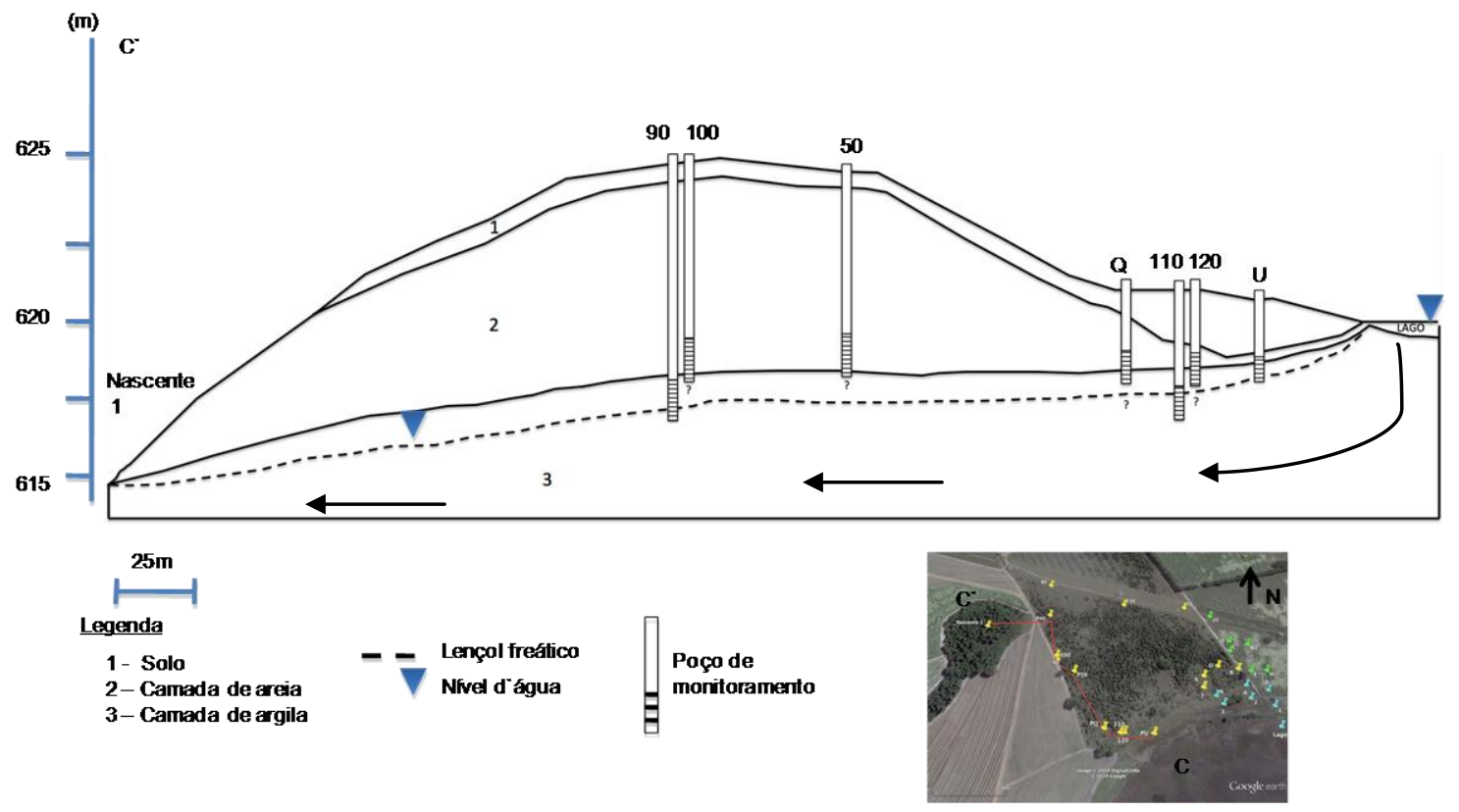

Figura 30. Modelo conceitual da área de estudos - Corte C-C' - nível de água em período de estiagem. 


\section{CONCLUSÃO}

Os pequenos lagos que ocorrem na Formação Rio Claro são feições geomorfológicas bastante comuns dessa formação, encontrando-se, em muitos casos, em topo de pequeno platô, circundados por drenagens de pequeno porte. A origem dessas feições provavelmente está associada a pequenas drenagens que foram entulhadas por sedimentos em seu curso alto ou, que o fluxo de água superficial foi interrompido devido a alguma feição estrutural cenozoica (ZAINE, 1994), sobrepostas por uma camada de baixa condutividade hidráulica. Em uma dessas lagoas, localizada a oeste da cidade de Rio Claro, foi estudado com detalhe a sua relação com o aquífero livre subjacente.

$\mathrm{Na}$ área de estudo, a Formação Rio Claro tem aproximadamente 30 metros de espessura e assenta-se sobre rochas sedimentares de baixa permeabilidade da Formação Corumbataí, com a precipitação e o escoamento superficial como as únicas fontes de alimentação da lagoa. Já a descarga se dá pela evaporação direta e pela recarga ao aquífero livre. Esse mecanismo de recarga do aquífero é comprovado pelos vários mapas potenciométricos traçados ao longo do tempo, que mostram que, independentemente do período do ano, há descarga da lagoa ao aquífero. A lagoa é perene e sensível a períodos de estiagem, mas quando com água, sempre tem característica influente em relação ao aquífero. Ela também se apresenta diretamente conectada ao aquífero e não se encontra suspensa em relação ao aquífero.

Observou-se que o fluxo da água subterrânea é contra a topografia (segue em direção à cota topográfica maior), podendo ser explicado pelos pontos de descarga do aquífero, que se dão nas drenagens que circundam essa feição. Uma dessas manifestações de descarga está associada a uma nascente ao oeste da lagoa (Figura 2).

Os resultados hidrogeoquímicos mostraram que é possível distinguir três grupos de águas, relacionadas diretamente com o tipo de ocupação do terreno.

A ocupação do terreno que circunda o lago dá se pela atividade agrícola das culturas de cana-de-açúcar e de eucalipto. O acompanhamento dos níveis de água subterrânea sob os eucaliptos e a cana-de-açúcar não mostrou variações expressivas entre si ao longo do ano. A geofísica com métodos elétricos mostrou variações significativas do nível de umidade 
da zona não saturada sob os eucaliptos e não acompanharam regime de chuva. É importante ressaltar que as chuvas nesses últimos períodos (e, sobretudo, aqueles na época da geofísica) foram anômalas, e as chuvas do ano anterior não permitiram o preenchimento completo do lago que está seco há, aproximadamente, um ano.

Com relação à estimativa de recarga, foram aplicados três métodos: aproximação darcyniana, balanço hídrico e variação de nível de água. O cálculo da variação de nível de água foi possível apenas para estimativa de recarga anual, devido à falta de dados mensais do nível de água. O método do balanço hídrico apresentou o menor valor e pode ser considerado o mais impreciso de todos, pois se baseia em dados indiretos de evapotranspiração real e não considera possíveis escoamentos superficiais.

A estimativa darcyniana registrou os maiores valores entre os métodos utilizados. Foram considerados os períodos seco e úmido, e o cálculo resultou em diferença de cerca de $20 \%$ em favor do período úmido. Diferentemente dos outros métodos, para a aproximação darcyniana, foi considerado um sistema estacionário, em que a diferença direta das cotas entre a lâmina de água da lagoa e da nascente seria a única responsável pelo fluxo da massa de água.

De acordo com a bibliografia e pelo próprio método, pode-se considerar o mais preciso, pois as obtenções de dados diretos dos níveis de água associam menores erros de procedimento, ajudadas pelas boas respostas do aquífero raso em eventos de chuva. Não foi possível estimar recargas mensais, pois muitos poços secaram durante o monitoramento, no entanto, os valores obtidos nos três métodos acompanharam a mesma ordem de grandeza. Os métodos de balanço hídrico e aproximação darcyniana podem variar bruscamente de acordo com as escolhas de valores para suas variáveis, o que os tornam muito sensíveis às condições de contorno local.

A utilização da técnica isotópica ajudou na definição da direção do fluxo da água subterrânea, uma vez que foi possível observar uma tendência sequencial nas posições relativas dos poços no gráfico de comparação com a reta meteórica, em que os poços mais próximos à lagoa apresentavam águas isotopicamente enriquecidas às águas distantes da lagoa. 


\section{Referências Bibliográficas}

ADEHNSON, L. A. G. 2013. Métodos geoelétricos aplicados à variação dos impactos do eucalipto nas águas subterrâneas. Estudo de caso em Rio Claro (SP). Trabalho de Formatura apresentado no Instituto de Geociências da Universidade de São Paulo USP.

AMORIM, M. C., ROSSATO, L.,TOMASELLA, J. 1999. Determinação da evapotranspiração potencial do Brasil, aplicando o modelo de Thornthwaite a um sistema de informação geográfica. RBRH - Revista Brasileira de Recursos Hídricos v.4 n.3 jul/set 1999, 83-90p.

ARANTES, E. J. 2003. Emprego de infiltrômetros na caracterização da interação rio e aquífero. Dissertação de Mestrado. São Carlos, SHS-EESC-USP.

ASSOCIAÇÃO BRASILEIRA DE PRODUTORES DE FLORESTA PLANTADA - ABRAF. Anuário estatístico da ABRAF 2013, ano base 2012/ABRAF - Brasília: ABRAF:2013.

BARLOW, P.M.; MOENCH, A.F., 1999. WTAQ-A computer program for calculating drawdowns and estimating hydraulic properties for confined and water-table aquifers: U.S. Geological Survey Water-Resources Investigations Report 99-4225, 74 p.

BARRETO, C. E. A. G. 2005. Water balance in the outcrop zone of Guarani Aquifer System through hydrogeologic monitoring in a representative basin. M.Sc. Dissertation. Escola de Engenharia de São Carlos, Universidade de São Paulo, São Carlos.

BAUMHARDT , E.; PAULA, S. C.; MAZIERO, E.; CRUZ, J. C.; SILVÉRIO DA SILVA, J. L. 2012. O uso do Water Table Fluctuation - WTF como estimativa de recarga direta em microbacias sob diferentes usos do solo. In: Anais do XI Simpósio de Recursos Hídricos do Nordeste. ABRH, v.1., 1-17p.

BJÖRNBERG, A. J. S.; LANDIM, P. M. B.; MEIRELLES, G. M. F. 1964a. - Restos de plantas modernas em níveis elevados na região de Rio Claro - São Paulo. Boletim Escola Engenharia de São Carlos, Universidade de São Paulo. Geologia 11: 37-57.

BJÖRNBERG, A. J. S.; MACIEL, A. C.; GANDOLFI, N. 1964b. - Notas sobre os depósitos modernos da região de Rio Claro - São Paulo. Boletim Escola Engenharia de São Carlos, Universidade de São Paulo. Geologia 11: 21-36.

BJÖRNBERG, A. E; LANDIN, P. M. B. 1966. Contribuição ao estudo da Formação Rio Claro (neocenozoicos). Boletim Sociedade Brasileira Geologia, 15 (4): 43-67. 
BOCANEGRA, E.; QUIROZ LONDOÑO, O. M.; MARTínEZ, D. E.; ROMANELLI, A. 2013. Quantification of the water balance and hydrogeological processes of groundwater -lake interactions in the Pampa Plain, Argentina - Environ Earth Sci (2013) 68:23472357.

BONOTTO, D.M. \& MANCINI, L.H. - 1992 - Estudo hidroquímico e isotópico dos aqüíferos de Rio Claro (SP). Geochim. Brasil., 6 (2): 153-167.

BOUWER, H.1989. The Bouwer and Rice slug test. Ground Water, n. 3, p. 304-309.

BOUWER, H.; RICE, R.C. 1989. Effect of water depth in groundwater recharge basins on infiltration rate Journal of Irrigation and Drainage Engineering. Div. Am Soc Civil En: 115(4):556 -568

BRAGA A. C. O. 2006. Métodos da eletrorresistividade e polarização induzida aplicados nos estudos da captação e contaminação de águas subterrâneas: uma abordagem metodológica e prática. 2006. Tese de Livre Docência, Instituto de Geociências e Ciências Exatas, Universidade Estadual Paulista (UNESP), Rio Claro, São Paulo, 121p.

CAINE, G.; CLARK,I. D. 1999. Tracing ground water recharge in an agricultural watershed with isotopes. Ontário, Canadá. Ground Water, Vol. 37, No.1 , January-February 1999.

CLARK, I.; FRITZ, P. 1997. Environmental isotopes in hydrogeology. Lewis Publishers. Boca Raton. 328p.

CETESB - COMPANHIA DE TECNOLOGIA E SANEAMENTO AMBIENTAL DO ESTADO DE SÃO PAULO 1988 Norma CETESB 6410 - Amostragem e monitoramento das águas subterrâneas. São Paulo, 21p.

COTTAS, L. R., 1983. Estudos geológico-geotécnicos aplicados ao planejamento urbano de Rio Claro- SP. São Paulo, SP. 171 p., v.2 (Tese de Doutoramento - Instituto de Geociências/USP).

CRAIG, H. 1961. Standard for reporting concentrations of dueterium and oxygen-18 in natural waters. Science, 133: 1833-1834.

CRAIG, H. 1961. Isotopic variations in meteoric waters. Science, 133: 1702-1703.

CUSTÓDIO, E., LLAMAS, R. 1976. Hidrología subterrânea. Omega S/A, Barcelona.

CUSTÓDIO, E.; LLAMAS, M. R., 1981. Hidrologia subterrânea. 2a ed. Barcelona, Ediciones Omega, v.1, 1157p.

CUSTÓDIO, E. 1998. Recarga a los acuíferos: Aspectos generals sobre el proceso, la evaluacion y la incerdidumbre. Boletin Geológico Y Minero. v. 109-4: 329-346. 
CUSTÓDIO, E. 2002. Aquifer overexplotation: What does it means? Hydrogeology Journal, 10 (2): 254-278.

DAMBRÓS, C. E.; SILVA J. L. S. 2013. Aplicação do método WTF para determinação de estimativas de recarga de aquífero: Comparação entre duas sub-bacias hidrográficas. RBRH - Revista Brasileira de Recursos Hídricos, XX Simpósio Brasileiro de Recursos Hídricos Bento Gonçalves, RS. 17-22 de Nov.2013.

DARLING, W.G.; BATH A.H. 1988. A stable isotope study of recharge process in the English chalk. Journal of Hydrology, 101: 31-46

DAVIDSON, J. 1985. "Setting aside the idea that eucalyptus are always bad". UNDP/ FAO project Bangladesh BGD/79/017, 1985 (Working Paper, 10).

DEVRIES, J. J.; SIMMERS, I. 2002. Groundwater recharge: an overview of processes and challenges. Hydrogeology Journal 10: 5-17.

DEPARTAMENTO DE ÁGUA E ENERGIA ELÉTRICA - DAEE, 1981. Estudo de Águas Subterrâneas, Região Administrativa 5, SP, São Paulo, v.2.

EMPRESA BRASILEIRA DE PESQUISA AGROPECUÁRIA - EMBRAPA, 2006. <http://www.agencia.cnptia.embrapa.br/Repositorio/Cana_irrigada_producao_000 fizvd3t102wyiv802hvm3jlwle6b8.pdf>, acesso em 17/05/2014.

FEITOSA, F.A.C.; Filho,J.M.; Feitosa, E.C.; Demetrio, J.G.A. 2008. Hidrogeologia: Conceitos e Aplicações. 3a ed. rev. e ampl. - Rio de Janeiro: CPRM: LABHID,2008. 812p.

FETTER, C. W. 2001. Applied Hydrogeology. Fourth Edition. Prentice Hall. 598p.

FLORENCE, R. G. 1981. The biology of the eucalypt forest. In: The Biology of Australian Plants. J. S. Pate e A. M. McComb (Ed.). University of Western Australia Press. 147180 .

FOELKEL, C. 2005. Minerais e nutrientes das árvores dos eucaliptos: Aspectos ambientais, fisiológicos, silviculturais e industriais acerca dos elementos inorgânicos presentes nas árvores. Eucaliptus Newsletters, n², out, 2005.

FOLK, R. L. 1968. Petrology of sedimentary rocks. , 182p, 1968.

FRANÇOSO, S. C.; AILLAUD, C.; QUEIROZ NETO, J. P. 1974. Depressões doliniformes do platô de Itapetininga, SP. Tentativa de interpretação. In: CONGRESSO BRASILEIRO DE GEOLOGIA, 28., Porto Alegre, 1974. Anais... Porto Alegre, SBG. v. 1, p. 85-90. 
FREEZE, R.A.; WINTHERSPOON, P.A. 1967. Theoretical analysis of regional groundwater flow, II: effect of table configuration and subsurface permeability variations. Water Resour Res 3(2): 623-634.

FREITAS, R. O.; MEZZALIRA, S.; ODA, G. H.; VIEIRA, P. C.; TORRES, C. C.; HACHIRO, J.; TOMINAGA, L. K.;DEHIRA, L. K.; MASSOLI, M.; AZEVEDO, A. A. B.; PRESSINOTI, M. M. N. 1979. Projeto levantamento geológico de formações superficiais. In: SIMPÓSIO REGIONAL DE GEOLOGIA SBG (2), 263-277p.

FÚLFARO, V. J.; SUGUIO, K. 1968. A Formação Rio Claro (Neocenozoicos) e seu ambiente de deposição. Boletim Instituto Geográfico e Geológico, 20: 45-60.

GALLAS, J. D. F. 2000. Principais métodos geoelétricos e suas aplicações em prospeç̧ão mineral, hidrogeologia, geologia de engenharia e geologia ambiental. Tese de Doutorado, Instituto de Geociências e Ciências Exatas, Universidade Estadual Paulista "Júlio de Mesquita Filho" (UNESP), Rio Claro, 174 p.

GAT, J. R. 1971. Comments on stable isotope method in regional groundwater investigation. Water Resource Research, 7: 980-993.

GEE, G.W.; WIERENGA, P.J.; ANDRASKI, B.J.; YOUNG, M.H.; FAYER, M.J.; AND ROCKHOLD, M.L.; 1994. Variations in water balance and recharge potential at three western desert sites. Soil Sci. Soc. Am. J., 58: 63-71.

GEORGE, R.J.; NULSEN, R.A.;FERDOWSIAN, R.; RAPER, G.P. 1999. Interactions between trees and groundwaters in recharge and discharge areas - a survey of Western Australian sites. J. Ag. Water Man, 39: 91-113.

GIBS, J.; WILD, F.D. 1999. Ground-water sampling: Preparations and purging methods at water-supply wells and monitoring wells. In: Wilde, F.D.; Radtke, D.B.; Gibs, J.; Iwatsubo, R.T. (eds.) National field manual for the collection of water-quality data, USGS.

GRIEVE, B. J. 1956. Studies in the water relations of plants. I- Transpiration of Western Australia (Swan Plain) sclerophylls. Journal of the Royal Society of Western Australia, 40: 15-30.

HALL, D. W.; RISSER, D. W. 1993. Effects of agricultural nutrient management on nitrogen fate and transport in Lancaster county, Pennsylvania. Water Resour Bull 29: 55-76.

HEALY, R. W.; COOK, P. G. 2002. Using ground-water levels to estimate recharge. Hydrogeology Journal. 10 (1): 91-109.

HOEFS, J. 1997. Stable Isotope Geochemistry. Ed. Springer-Verlag, Berlin, $4^{\text {th }}$ ed., 201p. 
HVORSLEV, M. J. 1951. Time lag and soil permeability in ground water observations. Bul. Army Corps of Engineers Waterway Experimentation Station, U. S. n. 36.

IBGE 2010.<http://www.sidra.ibge.gov.br/bda/tabela/listabl.asp?c=1612en=0eu=0ez=peo= 27ei=P $>$, acesso em 03/06/2014.

INSTITUTO DE PESQUISAS TECNOLÓGICAS DO ESTADO DE SÃO PAULO -IPT 1981. Mapa geomorfológico do Estado de São Paulo - escala 1:1000.000. São Paulo. (IPT. Série monografias).

INTERNATIONAL ATOMIC ENERGY AGENCY - IAEA, 2014. IAEA - International Atomic Energy Agency, http://www-naweb.iaea.org/napc/ih/IHS_resources_isohis.html acesso em novembro 2014.

INTERNATIONAL ATOMIC ENERGY AGENCY - IAEA, 2014. Disponível em <www.IAEA.com $\geq$, acesso em fevereiro, 2014.

JACOB, M. R. 1955. Growth Habits of the Eucalypt. Forest and Timber Bureau. Commonwealth of Australia, Camberra. 262pp.

LEE, J.; ROBINSON, C.; COUTURE, R. M. 2014. Effect of groundwater-lake on arsenic enrichment in freshwater beach aquifers. Environmental Science \& Technology. 48, 10174-10181.

LERNER, D. N., 1990. Groundwater recharge in urban areas. Atmospheric Environment. 24B (1): 29-33.

LERNER, D. N. 1997. Groundwater recharge. In: Seather, O.M.; de Carit, P. (eds.). Geochemical processes, weathering and groundwater recharge in catchments. A Bulkma, Rotterdã. p. 109-150.

LERNER, D. N. 2002. Identifying and quantifying urban recharge. A review. Hydrogeology Journal 10: 143-152

LIMA, W.P., 1990. Overland flow and soil and nutrient losses from Eucalyptus plantations. IPEF International, 1: 35-44.

LIMA, J. T.; CHAVES, M. B.; NOBRE, R. C. M. N; NOBRE, M. M. M. 2009. Aplicação da Variação do nível do lençol freático para Estimativa de recarga em Maceió-AL, Brasil. XVIII Simpósio Brasileiro de Recursos Hídricos Campo Grande, MS, 22 a 26 de novembro de 2009.

MARTIN, H.A.; SPECHT, R.L. 1962. Are mesic communities less drought resistant? A study on moisture relationships in dry sclerophyll forest at Inglewood, South Australia. Australian Journal Botany, 10: 106-18, 1962. 
MARTINS, V. T. S. 2008. Aplicação de Isótopos de Pb, Sr, H e O como traçadores da recarga e da contaminação de aquíferos metropolitanos: um exemplo da Bacia do Alto Tietê. Tese de Doutoramento, Instituto de Geociências, Universidade de São Paulo, 220p.

MAZIERO, T. A. 2005. Monitoramento de água subterrânea em Áreas Urbanas: Aspectos Quantitativos - Dissertação de Mestrado. São Carlos, SHS-EESC-USP.

MAZOR, E. 1991. Applied chemical and isotopic groundwater hydrology. Open University Press, Suffolk, Great Britain, 274p.

MILANI, E. J. 2004. Comentários sobre a origem e evolução tectônica da Bacia do Paraná. In: Mantesso Neto V., Bartorelli A., Carneiro C.D.R., Brito Neves B.B. (eds.) Geologia do Continente Sul-Americano: Evolução da Obra de Fernando Flávio Marques de Almeida. São Paulo, Editora Beca, p. 265-279.

MONDIN, M. 2005. Avaliação e quantificação do processo de recarga do aquífero livre e raso no Parque Ecológico do Tietê- SP. Dissertação de Mestrado - Instituto de Geociências da Universidade de São Paulo. Programa de pós-graduação em Recursos Minerais e Hidrogeologia $115 \mathrm{f}$.

MOON S.; WOO, N.C.; LEE, K.S. 2004. Statistical analysis of hydrographs and water-table fluctuation to estimate groundwater recharge. Journal of Hydrology, v.292, 1-4, 15june 2004, p.198-209.

MORA, A. L.; GARCIA C. H. 2000. A cultura do eucalipto no Brasil. Sociedade de Silvicultura. Universidade do Texas, 112p.

NETO, D. C.; CHANG, K.H. 2008. Aplicação do método de flutuação de nível da água para a estimativa de recarga - Exemplo do aquífero Rio Claro. Águas Subterrâneas, v.22, n.01, 39-48p.

NISWONGER. R. G.; ALLANDER, K. K.; JETON, A. E. 2014. Collaborative modelling and integrated decision support system analysis of a developed terminal lake basin. Journal of Hydrogeology 517, 521-537.

NORMA ABNT BR 15495, 2007. Poços de Monitoramento de Águas Subterrâneas em Aquíferos Granulares.

OLIVA, A. 2002. Estudo hidrogeológico da Formação Rio Claro no Município de Rio Claro- SP. Dissertação de Mestrado. Instituto de Geociências e Ciências Exatas - Unesp Rio Claro - SP.

OLIVA, A.; CHANG, H. K.; CAETANO-CHANG, M. R. 2005. Determinação da Condutividade Hidráulica da Formação Rio Claro: Análise Comparativa Através de Análise 
Granulométrica e Ensaios com Permeâmetro Guelph e Testes de Slug. Águas Subterrâneas, v. 19, n. 2 2, 1-18p.

OLIVA A. 2006. Estudo hidrogeológico da Formação Rio Claro no Município de Rio Claro - SP. Tese de Doutorado, Instituto de Geociências e Ciências Exatas, Universidade Estadual Paulista "Júlio de Mesquita Filho" (UNESP), Rio Claro, 196 p. Penteado, M. M. 1976. Geomorfologia do setor centro-ocidental da depressão periférica paulista. Instituto de Geografia - USP. Série Teses e Monografias n222, 86p.

PENTEADO, M. M. 1976. Geomorfologia do Setor Centro-Ocidental da Depressão Periférica Paulista. Tese de Doutoramento. Instituto de Geografia USP. Série Teses e Monografias no 22.

PENTEADO-ORELLANA, M. M. 1981. Estudo geomorfológico do sítio urbano de Rio Claro (SP). Notícia Geomorfológica, Campinas, 21 (42): 23-56.

POORE, M .E. D; FRIES, C. 1985. The ecological effects of eucalyptus. FAO, 1985.

PRYCH, E.A. 1998. Using chloride and chlorine-36 as soil-water tracers to estimate deep percolation at selected locations on the US Department of Energy Hanford Site, Washington. US Geol Surv Water-Supply Pap 2481:67

PRYOR, L. D 1976. The Biology of Eucalypts. The Institute of Biology, Studies in Biology no61.London, Edward Arnold, 80p.

PRADO, H.; OLIVEIRA, J. B.; ALMEIDA, C. L. F. 1981. Levantamento pedológico semidetalhado do Estado de São Paulo. Quadrícula de São Carlos. Escala 1:100.000. Instituto Agronômico de Campinas.

ROSANSKI, K.; ARAGUÁS-ARAGUÁS, L. AND GONFIANTINI, R. (1993). Isotopic patterns in modern global precipitation. In: Continental isotope Indicators of Climate, American Geophysical Union Monograph.

SCANLON, B. R; HEALY, W. H.; COOK, P. G. 2002. Choosing appropriate techniques for quantifying groundwater recharge. Hydrogeology Journal (2002) 10:18-39. SpringerVerlag 2002.

SCHRADER, A.; WINDER, F.; ERARSMUS, E. 2014. Using impacts of deep-level mining to research karst hydrology-a Darcy-based approach to predict the future of dried-up dolomitic springs in the Far West Rand goldfield (South Africa). Part 1: a conceptual model of recharge and inter-compartmental flow. Environmental Earth Sciences. November 2014, . 72, 9, 27 Apr 2014, p. 3549-3565. 
SAMPER, C. F. 1998. Evaluación de la recarga por la lluvia mediante balances de agua: Utilización, calibración e incertidumbres [Groundwater recharge by rainfall from water balances: Usage, Calibration, and uncertainties]. Boletin Geológico y Minero, 109, 347-370.

SANTOS, M. J. Z., 1986. Análise da variabilidade anual das precipitações em Rio Claro (SP). Revista de Geografia, São Paulo, 5/6 29-53p.

SARAIVA, F. A. 2010. Avaliação de métodos geofísicos no comportamento espacial de plumas de necrochorume. Tese de Doutorado, Instituto de Geociências, Universidade de São Paulo (USP), São Paulo, 93 p.

SENA, C.; DE MELO M. T. C. 2012. Groundwater-surface water interactions in a freshwater lagoon vulnerable to anthropogenic pressures (Pateira de Fermentelos, Portugal) Journal of Hydrology 466-467 (2012) 88-102.

SILVA, J. L. S.; FARIAS, P. V. C. 2013. Estimativa de recarga de água subterrânea em microbacia hidrográfica do Rio Vacacaí-Mirim. XX Simpósio Brasileiro de Recursos Hídricos, 2013.

SIMÕES, F. F. L. F.; FERNANDES, H. H.; SANTOS, R. R. SILVA, L. F.; ARAVENA, R.; GODOY, M. L.; PEREIRA FILHO, H.A.F. 2006. Caracterização hidrogeoquímica, avaliação da qualidade e da recarga de aquíferos do semiárido associados à mineração de urânio. (Caetité, BA) XIV Congresso Brasileiro de Águas Subterrâneas, 2006, SP.

SINCLAIR, R. 1980. Water potential and stomatal conductance of three Eucalyptus species in the Mount Lfty Ranges, South Australia: response to Summer drought. Australian Journal of Botany, 28: 499-510.

SOUZA, E. F; BERNARDO, S.; CARVALHO, J. A. 1999. Função de Produção da Cana de açúcar em Relação à Água para Três Cultivares, em Campos dos Goytacazes, RJ. Engenharia Agrícola, Jaboticabal - SP, v.19, n.1, 28-42p.

STRADIOTO, R. M. 2004. Estudo hidroquímico das águas superficiais e de chuva na área de ocorrência da Formação Rio Claro no município de Rio Claro. 59 f. (Trabalho de Formatura) - Instituto de Geociências e Ciências Exatas /Unesp- Rio Claro.

STRADIOTO, M.R.; KIANG, C.H. 2010. Caracterização hidrogeoquímica e isotópica das águas superficiais, pluviais e subterrâneas dos município de Rio Claro/SP. XVI Congresso Brasileiro de Águas Subterrâneas e XVII EncontroNacionande Perfuradores de Poços. 31 de agosto a 3 setembro de 2010. São Luís/MA.

TAKIZAWA, S. 2014. Soil Properties of Coupling Eucalyptus Plantation in Land-Use Sequences in Sao Paulo, Brazil. Master's Tesis. University of Tsukuba,71p. 
THORNTHWAITE, C. W. 1948. An approach towards a rational classification of climate. Geographical Review, New York, v.38, n. 1, 55- 94p.

TROPPMAIR, H. 1972. Atlas da qualidade ambiental e de vida de Rio Claro-SP. Instituto de Geociências e Ciências Exatas/UNESP,72 f.

TYLER, S. W.;CHAPMAM, J.B.;CONRAD, S.H.; HAMMERMEISTER, D.P.; BLOUT,D.O.; MILLER, J.J.; SULLY,M.J.; GINANNI,J.M. 1996. Soil-water flux in the southern Great Basin, United States: temporal and spatial variation over the last 120,000 years. Water Resources 32(6), p. 1481-1499.

US ENVIRONMENTAL PROTECTION AGENCY. 1995. Ground Water Sampling - A Workshop Summary. Proceedings from the Dallas, Texas November 30 - December 2, 1993 Workshop. ORD, Robert S. Kerr Environmental Research Laboratory. EPA/600/R94/205, January.

VASCONCELOS, S. M. S, 1996. Estimativa da Recarga Subterrânea a partir do Balanço Hídrico - Exemplo Fortaleza, CE. Revista de Geologia, v.7, Imp Uni. UFC, Fortaleza, 27-34p.

VASCONCELOS, S. M. S., 1999. Recarga do aquífero Dunas/Paleodunas, Fortaleza-CE. Tese de Doutoramento, Instituto de Geociências da Universidade de São Paulo, SP.

VIVIANI-LIMA, J. B. 2007. Estimativa de recarga em áreas urbanizadas: estudo de caso na bacia do Alto Tietê (SP). Tese de Doutorado IGc-USP, Programa de Recursos Minerais e Hidrogeologia.

WINTER, T. C. ; HARVEY J. W.; FRANKE; O.L. ALLEY; W.M. 1998. Ground water and surface water - A single Resource. U.S. Geological Survey Circular 1139. Denver, Colorado.

WINTER, T. C. 1999. Relation of streams, lakes, and wetlands to groundwater flow systems. Hydrogeol Journal. 1999 7:28-45.

WAHNFRIED, I. E HIRATA, R. 2005. Comparação de Métodos de Estimativa de Recarga de Aquíferos em Uma Planície Aluvionar na Bacia Hidrográfica do Alto Tietê, RBRH Revista Brasileira de Recursos Hídricos, v.10 n.2 Abr/Jun 2005, 15-25p.

WASSENAAR L.I. ATHANASOPOULOS, P., HENDRYB, M.J. 2011. Isotope hydrology of precipitation, surface and ground waters in the Okanagan Valley, British Columbia, Canada Journal of Hydrology, V. 411, 1-2, 6 Dec 2011 37-48

YOULTON, C. 2013. Quantificação experimental da alteração no balanço hídrico e erosão em um Neossolo Quartzarênico devido à substituição de pastagem por cana-de-açúcar. 62f. Tese (Doutorado) - Escola de Engenharia de São Carlos, Departamento de Hidráulica e Saneamento, Universidade de São Paulo, São Carlos. 
ZAINE, J. E. 1994. Geologia da Formação Rio Claro na Folha Rio Claro - SP, 90p. Dissertação de Mestrado - Instituto de Geociências e Ciências Exatas / Unesp-Rio Claro.

ZAINE, J. E. 2000. Mapeamento geológico-geotécnico por meio do método de detalhamento progressivo, ensaio de aplicação na área urbana do município de Rio Claro-SP. 160p. (Tese de Doutoramento - Instituto de Geociências e Ciências Exatas/Unesp-Rio Claro).

ZANETTI, N. 2012. Estimativa da vulnerabilidade natural do aquífero livre no município de Rio Claro/SP / Natália Zanetti. - Rio Claro : [s.n.], 2012 


\section{APÊNDICES}

Apêndice I. Série de Precipitação média coletada no Horto florestal de Rio Claro entre 1954 e 2013.

\begin{tabular}{|c|c|c|c|c|c|c|c|c|c|c|c|c|c|}
\hline & jan & fev & mar & $a b r$ & mai & jun & jul & ago & set & out & nov & dez & Total \\
\hline 1954 & 245,4 & 154,4 & 196,3 & 7,5 & 115,7 & 72,1 & 5,4 & 0,0 & 34,0 & 30,8 & 90,6 & 218,1 & 1170,2 \\
\hline 1955 & 259,2 & 115,6 & 205,2 & 89,0 & 55,0 & 14,0 & 16,3 & 106,7 & 2,1 & 93,1 & 152,9 & 300,2 & 1409,1 \\
\hline 1956 & 170,3 & 382,1 & 108,3 & 56,3 & 216,4 & 33,3 & 88,8 & 33,0 & 88,5 & 85,8 & 61,3 & 118,3 & 1442,3 \\
\hline 1957 & 342,6 & 188,5 & 142,3 & 85,0 & 54,6 & 19,0 & 111,5 & 84,9 & 138,4 & 119,9 & 123,8 & 175,8 & 1586,1 \\
\hline 1958 & 353,3 & 159,8 & 241,4 & 106,9 & 146,9 & 84,8 & 30,2 & 15,2 & 111,5 & 113,3 & 168,2 & 186,5 & 1717,8 \\
\hline 1959 & 215,9 & 194,2 & 195,6 & 69,9 & 41,0 & 17,5 & 9,6 & 63,5 & 14,0 & 122,2 & 115,2 & 191,9 & 1250,4 \\
\hline 1960 & 345,6 & 300,0 & 189,0 & 47,7 & 71,3 & 69,7 & 0,0 & 30,8 & 14,6 & 210,9 & 224,6 & 362,7 & 1866,9 \\
\hline 1961 & 117,3 & 258,8 & 106,5 & 80,2 & 86,4 & 24,4 & 3,8 & 19,8 & 0,8 & 49,8 & 222,4 & 210,6 & 1180,8 \\
\hline 1962 & 116,5 & 221,3 & 381,7 & 77,9 & 29,8 & 43,1 & 19,6 & 56,5 & 111,5 & 228,8 & 111,0 & 280,0 & 1677,7 \\
\hline 1963 & 313,1 & 104,4 & 98,3 & 0,0 & 0,0 & 0,0 & 0,0 & 0,0 & 2,8 & 148,5 & 177,5 & 116,0 & 960,6 \\
\hline 1964 & 116,5 & 173,5 & 28,5 & 11,7 & 63,4 & 12,0 & 68,5 & 14,5 & 112,7 & 152,8 & 114,7 & 323,0 & 1191,8 \\
\hline 1965 & 256,0 & 278,0 & 124,8 & 31,3 & 80,9 & 28,9 & 36,6 & 0,4 & 120,4 & 187,8 & 182,0 & 277,8 & 1604,9 \\
\hline 1966 & 203,0 & 217,3 & 175,2 & 20,8 & 74,9 & 0,0 & 0,2 & 3,5 & 51,3 & 188,2 & 197,4 & 452,3 & 1584,2 \\
\hline 1967 & \begin{tabular}{|l|}
377,7 \\
\end{tabular} & 134,7 & 229,2 & 10,1 & 0,0 & 67,7 & 11,3 & 4,2 & 115,6 & 214,8 & 178,8 & 257,5 & 1601,5 \\
\hline 1968 & 196,5 & 64,2 & 156,7 & 38,5 & 18,3 & 21,0 & 22,9 & 32,3 & 20,4 & 164,2 & 91,7 & 106,0 & 932,7 \\
\hline 1969 & 94,8 & 87,5 & 91,0 & 41,1 & 26,9 & 17,9 & 8,3 & 33,5 & 83,5 & 165,7 & 268,6 & 224,2 & 1143,2 \\
\hline 1970 & 412,5 & 280,8 & 74,3 & 79,8 & 62,7 & 57,1 & 21,4 & 108,8 & 101,5 & 75,2 & 224,2 & 168,1 & 1666,3 \\
\hline 1971 & 118,8 & 106,1 & 166,0 & 98,5 & 101,9 & 97,3 & 28,5 & 14,0 & 92,5 & 94,7 & 105,8 & 145,0 & 1169,2 \\
\hline 1972 & 325,6 & 189,8 & 101,7 & 48,3 & 50,8 & 2,7 & 133,1 & 86,9 & 100,6 & 210,2 & 174,6 & 102,7 & 1527,1 \\
\hline 1973 & 77,7 & 224,4 & 164,2 & 116,7 & 39,0 & 27,5 & 46,4 & 21,3 & 62,1 & 107,3 & 102,8 & 575,4 & 1564,6 \\
\hline
\end{tabular}




\begin{tabular}{|c|c|c|c|c|c|c|c|c|c|c|c|c|c|}
\hline & jan & fev & mar & $a b r$ & mai & jun & jul & ago & set & out & nov & dez & Total \\
\hline 1974 & 240,9 & 52,3 & 335,7 & 21,3 & 11,5 & 150,0 & 0,0 & 0,4 & 28,8 & 113,8 & 131,9 & 367,1 & 1453,5 \\
\hline 1975 & 131,3 & 239,2 & 57,7 & 35,8 & 14,6 & 0,3 & 43,4 & 0,0 & 74,5 & 99 & 298,8 & 296,7 & 1291,1 \\
\hline 1976 & 340,2 & 406,9 & 231,5 & 93,3 & 160,2 & 85,4 & 148,8 & 95,4 & 167,3 & 120,4 & 103,8 & 220,2 & 2173,3 \\
\hline 1977 & 291,3 & 18,8 & 152,9 & 107,7 & 6,3 & 53,5 & 10,2 & 49,8 & 140,0 & 49,2 & 227,1 & 473,1 & 1579,8 \\
\hline 1978 & 215,0 & 109,0 & 76,0 & 20,4 & 83,5 & 25,4 & 121,0 & 4,0 & 52,3 & 97,9 & 241,3 & 290,6 & 1336,5 \\
\hline 1979 & 95,6 & 257,9 & 85,6 & 95,0 & 181,9 & 0,0 & 38,8 & 48,3 & 108,5 & 131,3 & 209,6 & 221,7 & 1474,2 \\
\hline 1980 & 265,4 & 313,3 & 88,8 & \begin{tabular}{|l|}
137,7 \\
\end{tabular} & 13,3 & 164,4 & 0,0 & 20,2 & 95,4 & 83,8 & 308,5 & 206,3 & 1697,1 \\
\hline 1981 & 446,9 & 85,4 & 140,0 & 55,0 & 27,9 & 120,8 & 0,0 & 6,5 & 7,1 & 370,4 & 189,6 & 214,4 & 1664,0 \\
\hline 1982 & 312,3 & 180,0 & 290,0 & 19,6 & 92,9 & 164,4 & 30,0 & 15,0 & 20,8 & 265,4 & 171,3 & 227,3 & 1788,9 \\
\hline 1983 & 525,2 & 352,5 & 189,0 & 179,2 & 299,4 & 140,0 & 31,7 & 0,0 & 243,1 & 169,2 & 226,5 & 314,6 & 2670,2 \\
\hline 1984 & \begin{tabular}{|l|}
174,4 \\
\end{tabular} & 76,7 & 32,1 & 69,6 & 75,7 & 0,0 & 7,1 & 159,4 & 58,3 & 40 & 260,2 & 190,6 & 1144,1 \\
\hline 1985 & 293,8 & 104,0 & 240,2 & 138,3 & 55,2 & 32,3 & 0,0 & 25,8 & 60,0 & 17,9 & 108,3 & 113,1 & 1189,0 \\
\hline 1986 & 185,8 & 280,7 & 225,8 & 65,2 & 92,9 & 0,0 & 36,3 & 150,8 & 33,3 & 64,6 & 130,2 & 401,5 & 1667,1 \\
\hline 1987 & 314,8 & 180,2 & 82,7 & 74,4 & 201,5 & 47,5 & 17,7 & 7,3 & 104,8 & 122,7 & 200,6 & 239,2 & 1593,3 \\
\hline 1988 & 315,6 & 273,1 & 156,0 & 99,6 & 112,9 & 9,2 & 0,0 & 0,0 & 3,8 & 188,5 & 127,3 & 203,1 & 1489,2 \\
\hline 1989 & 270,4 & 453,1 & 172,9 & 40,4 & 78,3 & 70,8 & 92,1 & 16,7 & 90,2 & 65,0 & 137,7 & 370,6 & 1858,3 \\
\hline 1990 & 349,4 & 130,5 & 277,8 & 139,3 & 34,0 & 6,1 & 99,0 & 61,8 & 72,6 & 146,9 & 162,6 & 233,4 & 1713,4 \\
\hline 1991 & 150,6 & 236,1 & 512,0 & \begin{tabular}{|l|}
173,4 \\
\end{tabular} & 49,4 & 21,1 & 18,7 & 0,0 & 88,5 & 121,1 & 96,5 & 332,5 & 1799,9 \\
\hline 1992 & 78,3 & 55,1 & 228,3 & 75,9 & 110,8 & 0,0 & 52,2 & 16,8 & 107,3 & 119,6 & 183,3 & 125,5 & 1153,1 \\
\hline 1993 & 307,5 & 404,5 & 99,4 & 95,0 & 67,3 & 37,9 & 8,2 & 37,9 & 239,8 & 103,8 & 134,0 & 196,6 & 1731,9 \\
\hline 1994 & 172,4 & 190,2 & 154,7 & 55,9 & 88,5 & 35,7 & 15,6 & 0,0 & 3,2 & 124,4 & 221,6 & 259,1 & 1321,3 \\
\hline 1995 & 350,8 & 631,5 & 256,7 & 192,3 & 81,9 & 19,9 & 31,5 & 2,0 & 32,7 & 215,4 & 209,8 & 200,5 & 2225,0 \\
\hline 1996 & 489,8 & 247,1 & 273,7 & 149,7 & 86,4 & 20,1 & 0,3 & 40,8 & 267,7 & 183,7 & 242,9 & 211,4 & 2213,6 \\
\hline 1997 & 263,3 & 101,4 & 58,2 & 30,1 & 91,2 & 230,8 & 29,8 & 2,0 & 62,9 & 96,2 & 286,7 & 206,1 & 1458,7 \\
\hline
\end{tabular}




\begin{tabular}{|c|c|c|c|c|c|c|c|c|c|c|c|c|c|}
\hline & jan & fev & mar & $a b r$ & mai & jun & jul & ago & set & out & nov & dez & Total \\
\hline 1998 & 195,5 & 309,4 & 152,8 & 65,1 & 80,7 & 13,3 & 4,2 & 22,2 & 58,8 & 121,3 & 28,1 & 237,3 & 1288,7 \\
\hline 1999 & 485,2 & 335,6 & 210,5 & 56,6 & 34,4 & 80,3 & 0,7 & 0,0 & 100,3 & 50,8 & 77,6 & 169,7 & 1601,7 \\
\hline 2000 & 323,8 & 219,4 & 214,1 & 8,6 & 2,7 & 12,6 & 49,3 & 64,1 & 118,6 & 69,3 & 230,9 & 219,3 & 1532,7 \\
\hline 2001 & 110,8 & 236,0 & 102,6 & 33,1 & 61,5 & 11,6 & 13,3 & 56,1 & 78,3 & 182,6 & 70,2 & 230,3 & 1186,4 \\
\hline 2002 & 285,9 & 278,4 & 94,9 & 4,1 & 93,9 & 0,0 & 5,6 & 125,8 & 38,7 & 62,4 & 288,2 & 256,2 & 1534,1 \\
\hline 2003 & 411,2 & 113,3 & 96,9 & 42,3 & 45,8 & 15,6 & 3,5 & 16,3 & 25,6 & 109,2 & 229,0 & 227,5 & 1336,2 \\
\hline 2004 & 351,4 & 314,4 & 199,0 & 175,3 & 94,7 & 50,9 & 97,9 & 0,0 & 11,0 & 113,2 & 192,3 & 142,3 & 1742,4 \\
\hline 2005 & 482,2 & 72,6 & 167,5 & 32,6 & 93,6 & 48,1 & 3,9 & 19,3 & 81,1 & 79,7 & 142,5 & 175,5 & 1398,6 \\
\hline 2006 & 158,2 & 268,9 & 145,6 & 94,5 & 7,2 & 4,3 & 22,0 & 14,5 & 68,6 & 152,3 & 161,7 & 256,5 & 1354,3 \\
\hline 2007 & 364,9 & 183,3 & 123,9 & 41,1 & 62,2 & 15,5 & 168,8 & 0,0 & 0,6 & 134,7 & 119,7 & 218,6 & 1433,3 \\
\hline 2008 & 175,3 & 141,1 & 168,0 & 106,5 & 33,2 & 53,4 & 0,0 & 54,4 & 36,5 & 113,6 & 86,5 & 224,4 & 1192,9 \\
\hline 2009 & 286,6 & 225,3 & 157,8 & 25,3 & 43,4 & 28,7 & 42,9 & 85,0 & 131,3 & 116,8 & 168,2 & 332,3 & 1643,6 \\
\hline 2010 & 519,9 & 183,4 & 205,3 & 48,6 & 17,5 & 21,3 & 27,8 & 0,0 & 45,9 & 71,6 & 63,8 & 273,5 & 1478,6 \\
\hline 2011 & 569,2 & 241,5 & 203,5 & 196,1 & 10,9 & 41,5 & 1,6 & 9,6 & 18,0 & 222,6 & 188,3 & 193,9 & 1896,7 \\
\hline 2012 & 362,4 & 223,7 & 73,1 & 132,2 & 61,0 & 166,2 & 52,0 & 0,0 & 45,4 & 122,6 & 92,5 & 267,5 & 1598,6 \\
\hline 2013 & 256,2 & 197,4 & 124,6 & 142,6 & 139,5 & 81,9 & 49,7 & 4,3 & 42,1 & 96,8 & 0,0 & 0,0 & 1135,1 \\
\hline MÉDIA & 276,3 & 212,6 & 167,2 & 74,8 & 72,3 & 46,5 & 34,0 & 32,7 & 74,0 & 128,2 & 164,0 & 238,9 & 1521,5 \\
\hline
\end{tabular}


Apêndice II. Temperatura de 1994 a 2013 no Horto Rio Claro

\begin{tabular}{|c|c|c|c|c|c|c|c|c|c|c|c|c|}
\hline Ano/Mês & jan & fev & mar & $a b r$ & mai & jun & jul & ago & set & out & nov & dez \\
\hline 1994 & 24,90 & 23,08 & 23,41 & 21,86 & 20,09 & 16,28 & 18,38 & 19,92 & 23,17 & 24,69 & 24,25 & 24,90 \\
\hline 1995 & 25,00 & 23,86 & 23,55 & 21,95 & 18,86 & 18,15 & 19,25 & 21,69 & 21,75 & 22,49 & 23,90 & 24,12 \\
\hline 1996 & 24,88 & 24,48 & 23,96 & 22,35 & 18,64 & 17,44 & 16,83 & 19,87 & 20,69 & 22,87 & 23,16 & 24,43 \\
\hline 1997 & 23,76 & 24,86 & 23,43 & 21,68 & 19,20 & 17,28 & 18,43 & 19,84 & 22,83 & 23,58 & 24,73 & 25,21 \\
\hline 1998 & 25,69 & 24,83 & 25,03 & 22,48 & 18,71 & 17,13 & 18,20 & 21,35 & 21,96 & 21,86 & 23,70 & 24,65 \\
\hline 1999 & 24,54 & 23,97 & 24,63 & 21,91 & 18,71 & 17,47 & 19,08 & 19,56 & 21,78 & 22,36 & 22,97 & 24,68 \\
\hline 2000 & 24,46 & 24,18 & 23,80 & 22,34 & 19,51 & 19,08 & 16,93 & 19,66 & 21,30 & 25,42 & 23,89 & 24,25 \\
\hline 2001 & 25,35 & 25,28 & 25,07 & 23,79 & 19,35 & 18,46 & 18,79 & 20,87 & 22,22 & 23,58 & 24,82 & 24,02 \\
\hline 2002 & 24,03 & 23,37 & 25,74 & 24,85 & 20,48 & 20,12 & 18,19 & 22,01 & 21,14 & 26,88 & 24,39 & 25,22 \\
\hline 2003 & 24,36 & 26,34 & 24,23 & 22,81 & 18,98 & 19,79 & 19,05 & 18,89 & 22,61 & 23,92 & 23,67 & 24,87 \\
\hline 2004 & 23,69 & 23,56 & 23,20 & 22,65 & 18,38 & 17,69 & 17,72 & 19,85 & 24,48 & 21,97 & 23,79 & 24,17 \\
\hline 2005 & 24,35 & 25,14 & 24,58 & 23,63 & 20,95 & 19,33 & 18,12 & 21,22 & 21,31 & 24,50 & 23,87 & 23,86 \\
\hline 2006 & 25,28 & 24,23 & 24,64 & 22,28 & 18,35 & 18,33 & 18,99 & 21,38 & 21,41 & 23,82 & 23,85 & 24,86 \\
\hline 2007 & 24,31 & 25,45 & 25,58 & 23,68 & 19,25 & 19,07 & 17,95 & 20,69 & 24,14 & 25,71 & 23,53 & 24,87 \\
\hline 2008 & 23,74 & 24,61 & 23,79 & 22,22 & 18,94 & 18,80 & 18,48 & 21,18 & 21,06 & 24,28 & 24,21 & 23,90 \\
\hline 2009 & 23,97 & 24,76 & 25,02 & 22,63 & 20,97 & 16,78 & 18,79 & 19,72 & 22,41 & 23,27 & 25,92 & 24,64 \\
\hline 2010 & 24,81 & 25,85 & 24,97 & 22,57 & 19,40 & 17,84 & 19,66 & 20,22 & 23,04 & 22,74 & 24,01 & 25,06 \\
\hline 2011 & 24,00 & 24,01 & 22,50 & 21,60 & 17,50 & 15,40 & 17,80 & 19,50 & 20,40 & 22,20 & 21,80 & 23,10 \\
\hline 2012 & 21,80 & 24,40 & 23,20 & 22,00 & 18,10 & 18,00 & 17,00 & 19,00 & 21,10 & 24,10 & 23,30 & 25,00 \\
\hline 2013 & 22,80 & 23,50 & 23,00 & 20,60 & 17,90 & 16,50 & 17,80 & 20,40 & & & & \\
\hline MÉDIA & 24,3 & 24,5 & 24,2 & 22,5 & 19,1 & 17,9 & 18,3 & 20,3 & 22,0 & 23,7 & 23,9 & 24,5 \\
\hline
\end{tabular}


Apêndice III. Série temporal da variação do nível d'água

\begin{tabular}{|l|l|l|l|l|l|l|l|l|l|l|l|l|l|}
\hline Datas & A & B & C & D & E & F & G & H & I & J & K & L & M \\
\hline $28 / 11 / 2011$ & 2,35 & 3,30 & 5,2 & 3,51 & 3,1 & 2,47 & - & - & - & - & - & - & - \\
\hline $17 / 02 / 2012$ & 1,57 & 2,93 & 4,46 & 5,73 & 2,37 & 1,19 & - & - & - & - & - & - & - \\
\hline $15 / 3 / 2012$ & 3,07 & 3,73 & 6,2 & 5,65 & 4,62 & 1,17 & - & - & - & - & - & - & - \\
\hline $4 / 4 / 2012$ & 2,355 & 3,47 & 4,72 & 6,71 & 2,9 & 1,545 & - & - & - & - & - & - & - \\
\hline $5 / 7 / 2012$ & 2,04 & 3,13 & 4,74 & 5,535 & 2,55 & 1,26 & $-0,7$ & 3,02 & 1,86 & 3,78 & 2,47 & 2,81 & 5,345 \\
\hline $10 / 8 / 2012$ & 2,31 & 3,46 & 4,71 & 5,86 & 2,88 & 1,49 & 3,45 & 3,35 & $-s$ & 4,12 & 2,81 & 3,13 & 5,59 \\
\hline $5 / 11 / 2012$ & 3,21 & 4,40 & 5,65 & 6,78 & 3,81 & 2,12 & $-0,7$ & 4,17 & $-s$ & 5,06 & 3,75 & 4,04 & 6,48 \\
\hline $16 / 4 / 2013$ & 3,31 & 4,66 & 6,00 & 7,22 & 4,04 & 2,47 & $-0,7$ & 4,17 & $-s$ & 5,51 & 3,75 & 4,29 & 6,96 \\
\hline $15 / 3 / 2013$ & 4,2 & 4,98 & 6,22 & 7,41 & 4,35 & 2,72 & $-0,7$ & 4,17 & $-s$ & 5,51 & 4,13 & 4,85 & 6,96 \\
\hline $26 / 9 / 2013$ & - & - & - & - & - & - & - & - & - & - & - & - & - \\
\hline $17 / 12 / 2013$ & 4,18 & 5,56 & 6,62 & 7,57 & 4,35 & 3,03 & 5,3 & $-s$ & $-s$ & $-s$ & 4,33 & 4,69 & 7,62 \\
\hline $12 / 6 / 2014$ & 4,24 & 6,34 & 6,64 & 7,61 & 5,75 & 3,36 & $-s$ & $-s$ & $-s$ & $-s$ & $-s$ & $-s$ & 8,535 \\
\hline $22 / 6 / 2014$ & - & & & & $-s$ & $-s$ & $-s$ & $d$ & $d$ & $d$ & $d$ & $d$ & \\
\hline $15 / 07 / 2014$ & - & & & & $-s$ & $-s$ & $-s$ & $d$ & $d$ & $d$ & $d$ & $d$ & \\
\hline
\end{tabular}

\begin{tabular}{|l|l|l|l|l|l|l|l|l|l|l|l|l|l|}
\hline Datas & N & O & Q & R & S & U & 1 & 2 & 3 & 20 & 30 & 40 & 50 \\
\hline $28 / 11 / 2011$ & - & - & - & - & - & - & - & - & - & - & - & - & - \\
\hline $17 / 02 / 2012$ & - & - & - & - & - & - & - & - & - & - & - & - & - \\
\hline $15 / 3 / 2012$ & - & - & - & - & - & - & - & - & - & - & - & - & - \\
\hline $4 / 4 / 2012$ & - & - & - & - & - & - & - & - & - & - & - & - & - \\
\hline $5 / 7 / 2012$ & 1,00 & 4,08 & - & - & - & - & - & - & - & - & - & - & - \\
\hline $10 / 8 / 2012$ & 1,28 & 4,62 & - & - & - & - & 0,13 & 0,28 & 0,26 & - & - & - & - \\
\hline $5 / 11 / 2012$ & -5 & 5,64 & - & - & - & - & 0,71 & 0,96 & 0,46 & - & - & - & - \\
\hline
\end{tabular}




\begin{tabular}{|l|l|l|l|l|l|l|l|l|l|l|l|l|l|}
\hline Datas & N & O & Q & $R$ & S & U & 1 & 2 & 3 & 20 & 30 & 40 & 50 \\
\hline $16 / 4 / 2013$ & $-s$ & 6,03 & - & - & - & - & 0,67 & 0,61 & $-s$ & - & - & - & - \\
\hline $15 / 3 / 2013$ & $-s$ & 6,18 & - & - & - & - & 0,83 & 0,63 & $-s$ & - & - & - & - \\
\hline $26 / 9 / 2013$ & $-s$ & & 3,16 & 1,89 & 2,03 & 1,84 & $-s$ & $-s$ & $-s$ & 10,69 & 14,55 & 10,08 & 8,02 \\
\hline $17 / 12 / 2013$ & $-s$ & 6,76 & 3,88 & 2,06 & 2,29 & 1,57 & $-s$ & $-s$ & $-s$ & 10,84 & 15,88 & $-s$ & 8,98 \\
\hline $12 / 6 / 2014$ & $-s$ & 7,5 & 5,15 & d & d & 2,97 & $-s$ & $-s$ & $-s$ & 10,83 & 15,87 & $-s$ & 9,58 \\
\hline $22 / 6 / 2014$ & $-s$ & $-s$ & $-s$ & d & d & & $-s$ & $-s$ & $-s$ & - & - & $-s$ & $-s$ \\
\hline $15 / 07 / 204$ & $-s$ & $-s$ & 4,76 & d & d & 3,03 & $-s$ & $-s$ & $-s$ & 10,80 & $-s$ & $-s$ & 10,79 \\
\hline
\end{tabular}

\begin{tabular}{|c|c|c|c|c|c|c|c|}
\hline Datas & 60 & 70 & 80 & 90 & 110 & 120 & 130 \\
\hline $28 / 11 / 2011$ & - & - & - & - & - & - & - \\
\hline $17 / 02 / 2012$ & - & - & - & - & - & - & - \\
\hline $15 / 3 / 2012$ & - & - & - & - & - & - & - \\
\hline $4 / 4 / 2012$ & - & - & - & - & - & - & - \\
\hline $5 / 7 / 2012$ & - & - & - & - & - & - & - \\
\hline $10 / 8 / 2012$ & - & - & - & - & - & - & - \\
\hline $5 / 11 / 2012$ & - & - & - & - & - & - & - \\
\hline $16 / 4 / 2013$ & - & - & - & - & - & - & - \\
\hline $15 / 3 / 2013$ & - & - & - & - & - & - & - \\
\hline $26 / 9 / 2013$ & 5,53 & - & - & - & - & - & - \\
\hline $17 / 12 / 2013$ & $-s$ & - & - & - & - & - & - \\
\hline $12 / 6 / 2014$ & $-s$ & - & - & - & - & - & - \\
\hline $22 / 6 / 2014$ & $-s$ & 13,07 & 16,795 & 11,4 & 11,33 & 3,50 & 3,50 \\
\hline $15 / 07 / 204$ & $-s$ & 13,05 & 16,91 & 11,53 & 11,47 & 3,79 & 3,80 \\
\hline
\end{tabular}

d = destruídos ; - = não existe ; -s = secos

Apêndice IV. Tabela de resultados químicos 


\begin{tabular}{|c|c|c|c|c|c|c|c|c|c|c|c|c|c|c|c|c|c|c|c|c|}
\hline & data & $\begin{array}{l}\text { temp } \\
\text { (oC) }\end{array}$ & $\begin{array}{l}\text { EC } \\
\text { (uS/cm) }\end{array}$ & $\mathrm{pH}$ & $\mathrm{O} 2(\%)$ & $\begin{array}{l}\text { ORP } \\
(\mathrm{mV})\end{array}$ & $\begin{array}{l}\mathrm{Na}^{+} \\
(\mathrm{mg} / \mathrm{L})\end{array}$ & $\begin{array}{l}\mathrm{K}^{+} \\
(\mathrm{mg} / \mathrm{L}) \\
\end{array}$ & $\begin{array}{l}\mathrm{Ca}^{2+} \\
(\mathrm{mg} / \mathrm{L})\end{array}$ & $\begin{array}{l}\mathrm{Mg}^{2+} \\
(\mathrm{mg} / \mathrm{L})\end{array}$ & $\begin{array}{l}\mathrm{Mn}^{2+} \\
(\mathrm{mg} / \mathrm{L})\end{array}$ & $\begin{array}{l}\mathrm{Fe} \\
(\mathrm{mg} / \mathrm{L})\end{array}$ & $\begin{array}{l}\mathrm{F}^{-} \\
(\mathrm{mg} / \mathrm{L})\end{array}$ & $\begin{array}{l}\mathrm{Cl}^{-} \\
(\mathrm{mg} / \mathrm{L})\end{array}$ & $\begin{array}{l}\mathrm{NO}_{2}^{-} \\
(\mathrm{mg} / \mathrm{L})\end{array}$ & $\begin{array}{l}\mathrm{Br}^{-} \\
(\mathrm{mg} / \mathrm{L})\end{array}$ & $\begin{array}{l}\mathrm{NO}_{3}^{-} \\
(\mathrm{mg} / \mathrm{L})\end{array}$ & $\begin{array}{l}\mathrm{HPO}_{4}{ }^{2-} \\
(\mathrm{mg} / \mathrm{L})\end{array}$ & $\begin{array}{l}\mathrm{SO}_{4}{ }^{2-} \\
(\mathrm{mg} / \mathrm{L})\end{array}$ & $\begin{array}{l}\mathrm{HCO}_{3}^{-} \\
(\mathrm{mg} / \mathrm{L}) \\
\end{array}$ \\
\hline A & $\begin{array}{l}\text { nov/ } \\
11\end{array}$ & 26,20 & 122,20 & 5,13 & 57,00 & - & 0,60 & 1,20 & 1,80 & 0,30 & 0,20 & 0,73 & 0,08 & 3,00 & 0,00 & 0,01 & 2,60 & 0,13 & 2,30 & \\
\hline B & $\begin{array}{l}\text { nov/ } \\
11\end{array}$ & 26,30 & 117,20 & 4,89 & 34,00 & - & 3,20 & 0,40 & 2,40 & 0,10 & 0,00 & 1,42 & 0,08 & 4,30 & 0,01 & 0,01 & 0,40 & 0,05 & 0,30 & \\
\hline C & $\begin{array}{l}\text { nov/ } \\
11 \\
\end{array}$ & 24,50 & 39,00 & 4,99 & 45,00 & - & 6,30 & 0,40 & 1,40 & 0,10 & 0,00 & 0,18 & 0,09 & 5,30 & 0,01 & 0,01 & 6,50 & 0,04 & 0,20 & \\
\hline D & $\begin{array}{l}\text { nov/ } \\
11 \\
\end{array}$ & 28,50 & 72,70 & 5,64 & 37,00 & - & 3,50 & 0,30 & 8,90 & 0,40 & 0,00 & 0,10 & 0,09 & 1,70 & 0,01 & 0,00 & 5,40 & 0,14 & 0,50 & \\
\hline $\mathrm{E}$ & $\begin{array}{l}\text { nov/ } \\
11 \\
\end{array}$ & 26,30 & 338,00 & 5,48 & 31,00 & - & 3,70 & 6,80 & 20,80 & 9,20 & 0,20 & 0,15 & 0,13 & 20,60 & 0,06 & 0,02 & 120,60 & 0,03 & 1,10 & \\
\hline $\mathrm{F}$ & $\begin{array}{l}\text { nov/ } \\
11 \\
\end{array}$ & 24,10 & 180,00 & 5,51 & 39,00 & - & 6,80 & 3,00 & 15,70 & 1,60 & 0,10 & 0,13 & 0,57 & 13,20 & 0,04 & 0,04 & 44,80 & 0,05 & 2,00 & \\
\hline A & $\begin{array}{l}\text { mar/ } \\
12\end{array}$ & 24,00 & 59,60 & 5,87 & 3,51 & 115,60 & 1,00 & 0,20 & 1,60 & 0,14 & 0,05 & 0,15 & 0,02 & 1,36 & 0,01 & 0,00 & 0,96 & 0,00 & 1,67 & 0,00 \\
\hline B & $\begin{array}{l}\text { mar/ } \\
12\end{array}$ & 23,30 & 59,10 & 5,75 & 2,60 & 136,00 & 5,00 & 0,90 & 1,33 & 0,11 & 0,03 & 2,61 & 0,03 & 6,85 & 0,01 & 0,00 & 0,97 & 0,03 & 0,11 & 0,00 \\
\hline C & $\begin{array}{l}\text { mar/ } \\
12 \\
\end{array}$ & 23,60 & 19,60 & 5,49 & 1,40 & 153,30 & 6,20 & 0,20 & 2,50 & 0,11 & 0,04 & 2,36 & 0,03 & 4,51 & 0,01 & 0,00 & 7,23 & 0,00 & 0,03 & 0,00 \\
\hline D & $\begin{array}{l}\text { mar/ } \\
12\end{array}$ & 24,10 & 19,90 & 7,35 & 5,28 & 123,60 & 4,90 & 1,10 & 5,61 & 0,42 & 0,05 & 0,55 & 0,12 & 2,84 & 0,01 & 0,00 & 2,60 & 0,02 & 0,09 & 0,00 \\
\hline $\mathrm{E}$ & $\begin{array}{l}\text { mar/ } \\
12 \\
\end{array}$ & & & & & & 2,40 & 7,60 & 11,63 & 11,69 & 0,21 & 1,21 & 0,11 & 21,58 & 0,03 & 0,01 & 90,27 & 0,05 & 0,06 & 0,00 \\
\hline $\mathrm{F}$ & $\begin{array}{l}\text { mar/ } \\
12 \\
\end{array}$ & 24,00 & 207,30 & 6,64 & 3,70 & 102,50 & 2,10 & 2,40 & 24,37 & 7,07 & 0,75 & 16,83 & 0,07 & 8,87 & 0,06 & 0,07 & 1,48 & 0,01 & 0,29 & 0,00 \\
\hline A & $\begin{array}{l}\text { abr/ } \\
12 \\
\end{array}$ & 24,40 & 170,00 & 6,59 & 2,90 & 115,60 & 4,60 & 4,10 & 5,67 & 0,48 & 0,09 & 2,02 & 0,05 & 7,51 & 0,01 & 0,04 & 0,17 & 0,03 & 0,92 & 19,25 \\
\hline B & $\begin{array}{l}a b r / \\
12 \\
\end{array}$ & 24,00 & 48,00 & 6,15 & 1,90 & 136,00 & 5,10 & 2,00 & 6,28 & 0,86 & 0,21 & 1,13 & 0,04 & 4,49 & 0,01 & 0,01 & 1,41 & 0,01 & 0,39 & 33,25 \\
\hline $\mathrm{C}$ & $\begin{array}{l}\text { abr/ } \\
12 \\
\end{array}$ & 24,10 & 76,90 & 6,21 & 3,70 & 153,30 & 7,00 & 3,50 & 9,30 & 2,98 & 0,15 & 1,79 & 2,30 & 7,64 & 0,04 & 0,02 & 2,50 & 0,02 & 0,35 & \begin{tabular}{|l}
44,07 \\
\end{tabular} \\
\hline D & $\begin{array}{l}a b r / \\
12 \\
\end{array}$ & 24,50 & 23,90 & 6,12 & 5,90 & 123,60 & 3,60 & 0,70 & 3,39 & 0,16 & 0,02 & 0,07 & 0,03 & 1,44 & 0,02 & 0,01 & 3,99 & 0,02 & 0,04 & 10,22 \\
\hline E & $\begin{array}{l}\mathrm{abr} / \\
12\end{array}$ & 24,30 & 344,30 & 6,53 & 3,50 & & 2,20 & 7,20 & 37,54 & 11,98 & 0,89 & 0,89 & 0,09 & 23,03 & 0,13 & 0,03 & 62,31 & 0,01 & 1,96 & 90,40 \\
\hline $\mathrm{F}$ & $\begin{array}{l}a b r / \\
12 \\
\end{array}$ & 24,40 & 49,70 & 5,78 & 4,00 & 102,50 & 1,80 & 1,00 & 7,90 & 2,08 & 7,26 & 4,26 & 0,06 & 9,25 & 0,02 & 0,03 & 5,66 & 0,02 & 0,19 & 20,58 \\
\hline A & jul/12 & 21,40 & 18,50 & 5,20 & 3,49 & 266,30 & & & & & & & & & & & & & & 12,74 \\
\hline $\mathrm{B}$ & $\mathrm{jul} / 12$ & & & & & & & & & & & & & & & & & & & 0,00 \\
\hline C & $\mathrm{jul} / 12$ & 22,70 & 25,00 & 5,81 & 1,87 & 186,80 & 5,00 & 1,30 & 3,93 & 1,17 & 0,12 & 5,41 & 0,06 & 6,89 & 0,01 & 0,02 & 0,21 & 0,04 & 0,06 & 28,41 \\
\hline $\mathrm{D}$ & $\mathrm{jul} / 12$ & 23,00 & 22,30 & 5,26 & 3,40 & 222,80 & 3,70 & 0,10 & 0,55 & 0,12 & 0,01 & 0,26 & 0,07 & 0,59 & 0,01 & 0,01 & 6,16 & 0,08 & 0,05 & 4,51 \\
\hline$E$ & jul/12 & 23,80 & 216,60 & 6,25 & 1,12 & 127,20 & 1,30 & 8,80 & 16,00 & 8,88 & 0,31 & 0,64 & 0,11 & 16,61 & 0,06 & 0,01 & 58,62 & 0,02 & 0,26 & 36,04 \\
\hline $\mathrm{F}$ & jul/12 & 22,60 & 36,40 & 4,95 & 0,26 & 164,60 & 1,40 & 0,70 & 1,79 & 0,60 & 0,02 & 0,40 & 0,07 & 4,26 & 0,02 & 0,03 & 3,05 & 0,02 & 0,43 & 2,97 \\
\hline $\mathrm{G}$ & $\mathrm{jul} / 12$ & & & & & & & & & & & & & & & & & & & \\
\hline $\mathrm{H}$ & $\mathrm{jul} / 12$ & 24,40 & 100,50 & 5,40 & 2,91 & 124,00 & 1,90 & 0,40 & 10,28 & 2,53 & 0,07 & 0,13 & 0,13 & 6,24 & 0,02 & 0,00 & 41,76 & 0,02 & \begin{tabular}{|l|}
0,07 \\
\end{tabular} & 4,12 \\
\hline 1 & $\mathrm{jul} / 12$ & & & & & & & & & & & & & & & & & & & \\
\hline J & $\mathrm{jul} / 12$ & 21,50 & 99,20 & 5,96 & 1,52 & 178,80 & 2,10 & 14,20 & 5,85 & 0,81 & 0,11 & 0,16 & 0,06 & 8,09 & 0,03 & 0,00 & 26,04 & 0,03 & 0,09 & 13,41 \\
\hline $\begin{array}{l}\mathrm{K} \\
\mathrm{L}\end{array}$ & $\begin{array}{l}\mathrm{jul} / 12 \\
\mathrm{jul} / 12\end{array}$ & 22,40 & 574,00 & 4,50 & 0,70 & 246,20 & 2,60 & 12,40 & 10,67 & 26,81 & 0,40 & 0,07 & 0,56 & 34,75 & 0,08 & 0,02 & 272,64 & 0,02 & 0,19 & 2,19 \\
\hline M1 & $\mathrm{jul} / 12$ & 2,20 & 120,80 & 7,41 & 0,30 & 22,90 & 0,90 & 2,30 & 17,01 & 2,28 & 0,10 & 2,25 & 0,23 & 2,21 & 0,01 & 0,00 & 0,03 & 0,02 & 0,06 & 57,61 \\
\hline M2 & jul/12 & & & & & & & & & & & & & & & & & & & \\
\hline $\mathrm{N}$ & $\mathrm{jul} / 12$ & 19,60 & 22,50 & 5,26 & 0,86 & 213,50 & 0,60 & 0,10 & 3,40 & 0,25 & 0,09 & 0,22 & 0,03 & 1,59 & 0,01 & 0,02 & 0,04 & 0,02 & 0,16 & 9,49 \\
\hline 0 & $\mathrm{jul} / 12$ & & & & & & 7,40 & 1,80 & 10,85 & 2,63 & 0,29 & 8,82 & 0,13 & 1,31 & 0,01 & 0,01 & 0,01 & 0,03 & 0,26 & 64,38 \\
\hline 1 & $\mathrm{jul} / 12$ & & & & & & & & & & & & & & & & & & & \\
\hline 2 & $\mathrm{jul} / 12$ & 19,40 & 37,60 & 6,02 & 0,20 & 101,00 & 0,40 & \begin{tabular}{|l|}
4,00 \\
\end{tabular} & 2,39 & 0,93 & 0,20 & 2,18 & 0,12 & 1,80 & 0,01 & 0,02 & 0,11 & 0,04 & 0,48 & 12,48 \\
\hline 3 & $\mathrm{jul} / 12$ & 18,00 & 27,50 & 5,33 & 0,37 & 159,50 & 0,30 & 1,70 & 4,76 & 0,93 & 0,28 & 1,19 & 0,08 & 1,14 & 0,01 & 0,02 & 0,12 & 0,02 & 0,77 & 12,21 \\
\hline $\mathrm{A}$ & $\begin{array}{l}\text { nov/ } \\
12 \\
\end{array}$ & 22,10 & 39,20 & 4,80 & 3,70 & 466,00 & 0,40 & 0,50 & 0,71 & 0,16 & 0,01 & 0,07 & 0,11 & 1,48 & 0,01 & 0,13 & 0,68 & 0,04 & 1,62 & 0,00 \\
\hline B & $\begin{array}{l}\text { nov/ } \\
12 \\
\end{array}$ & & & & & & 5,00 & 0,40 & 1,35 & 0,13 & 0,01 & 0,03 & 0,05 & 2,16 & 0,01 & 0,01 & 4,71 & 0,23 & 0,38 & 0,00 \\
\hline C & $\begin{array}{l}\text { nov/ } \\
12\end{array}$ & & & 5,50 & & & & & & & & & & & & & & & & \\
\hline D & $\begin{array}{l}\text { nov/ } \\
12\end{array}$ & 24,00 & 26,80 & 4,82 & 4,91 & 447,50 & 4,90 & 0,10 & 0,68 & 0,06 & & 0,11 & 0,07 & 0,50 & 0,01 & 0,01 & 8,43 & 0,05 & 0,05 & 3,08 \\
\hline $\mathrm{E}$ & $\begin{array}{l}\text { nov/ } \\
12\end{array}$ & 24,60 & 153,90 & 5,18 & 5,37 & 428,40 & 1,10 & 8,40 & 10,37 & 6,56 & 0,18 & 0,23 & 0,17 & 11,21 & 0,03 & 0,01 & 61,54 & 0,03 & 0,18 & 4,58 \\
\hline $\mathrm{F}$ & $\begin{array}{l}\text { nov/ } \\
12 \\
\end{array}$ & 22,80 & 24,20 & 4,50 & 0,88 & 443,20 & 1,00 & 0,40 & 1,16 & 0,36 & 0,01 & 0,70 & 0,07 & 2,29 & 0,01 & 0,04 & 0,44 & 0,06 & 0,35 & 0,00 \\
\hline $\mathrm{J}$ & $\begin{array}{l}\text { nov/ } \\
12\end{array}$ & 22,60 & 0,70 & 5,65 & 4,00 & 414,01 & 0,40 & 1,70 & 9,16 & 0,67 & 0,02 & 0,07 & 0,04 & 1,90 & 0,01 & 0,00 & 1,05 & 0,03 & 0,13 & 5,98 \\
\hline $\mathrm{K}$ & $\begin{array}{l}\text { nov/ } \\
12 \\
\end{array}$ & 21,70 & 105,00 & 5,49 & 3,04 & 395,80 & 0,60 & 0,10 & 10,17 & 0,86 & 0,02 & 0,10 & 0,02 & 0,11 & 0,01 & 0,01 & 0,25 & 0,02 & 0,14 & 5,36 \\
\hline
\end{tabular}




\begin{tabular}{|c|c|c|c|c|c|c|c|c|c|c|c|c|c|c|c|c|c|c|c|c|}
\hline & data & $\begin{array}{l}\text { temp } \\
\left({ }^{\circ} \mathrm{C}\right)\end{array}$ & $\begin{array}{l}\text { EC } \\
(\mathrm{uS} / \mathrm{cm})\end{array}$ & $\mathrm{pH}$ & $02(\%)$ & $\begin{array}{l}\text { ORP } \\
(\mathrm{mV})\end{array}$ & $\begin{array}{l}\mathrm{Na}^{+} \\
(\mathrm{mg} / \mathrm{L})\end{array}$ & $\begin{array}{l}\mathrm{K}^{+} \\
(\mathrm{mg} / \mathrm{L})\end{array}$ & $\begin{array}{l}\mathrm{Ca}^{2+} \\
(\mathrm{mg} / \mathrm{L}) \\
\end{array}$ & $\begin{array}{l}\mathrm{Mg}^{2+} \\
(\mathrm{mg} / \mathrm{L}) \\
\end{array}$ & $\begin{array}{l}\mathrm{Mn}^{2+} \\
(\mathrm{mg} / \mathrm{L}) \\
\end{array}$ & $\begin{array}{l}\mathrm{Fe} \\
(\mathrm{mg} / \mathrm{L})\end{array}$ & $\begin{array}{l}\mathrm{F}^{-} \\
(\mathrm{mg} / \mathrm{L})\end{array}$ & $\begin{array}{l}\mathrm{Cl}^{-} \\
(\mathrm{mg} / \mathrm{L})\end{array}$ & $\begin{array}{l}\mathrm{NO}_{2}^{-} \\
(\mathrm{mg} / \mathrm{L})\end{array}$ & $\begin{array}{l}\mathrm{Br}^{-} \\
(\mathrm{mg} / \mathrm{L})\end{array}$ & $\begin{array}{l}\mathrm{NO}_{3}^{-} \\
(\mathrm{mg} / \mathrm{L})\end{array}$ & $\begin{array}{l}\mathrm{HPO}_{4}{ }^{2-} \\
(\mathrm{mg} / \mathrm{L}) \\
\end{array}$ & $\begin{array}{l}\mathrm{SO}_{4}{ }^{2-} \\
(\mathrm{mg} / \mathrm{L})\end{array}$ & $\begin{array}{l}\mathrm{HCO}_{3}{ }^{-} \\
(\mathrm{mg} / \mathrm{L})\end{array}$ \\
\hline L & $\begin{array}{l}\text { nov/ } \\
12 \\
\end{array}$ & & & & & & & & & & & & & & & & & & & 0,00 \\
\hline M1 & $\begin{array}{l}\text { nov/ } \\
12 \\
\end{array}$ & 23,70 & 113,40 & 6,05 & 0,64 & 271,10 & 1,50 & 1,90 & 16,86 & 2,50 & 0,14 & 0,79 & 0,08 & 2,23 & 0,01 & 0,01 & 0,13 & 0,01 & 0,14 & 55,58 \\
\hline M2 & $\begin{array}{l}\text { nov/ } \\
12 \\
\end{array}$ & & & & & & & & & & & & & & & & & & & \\
\hline $\mathrm{N}$ & $\begin{array}{l}\text { nov/ } \\
12 \\
\end{array}$ & & & & & & & & & & & & & & & & & & & \\
\hline 0 & $\begin{array}{l}\text { nov/ } \\
12\end{array}$ & 22,70 & 114,90 & 6,04 & 0,41 & 299,30 & 12,60 & 2,00 & 11,01 & 2,37 & 0,36 & 0,79 & 0,17 & 1,59 & 0,01 & 0,00 & 0,23 & 0,02 & 0,59 & 58,23 \\
\hline 1 & $\begin{array}{l}\text { nov/ } \\
12 \\
\end{array}$ & 25,10 & 34,10 & 4,89 & 3,70 & 400,40 & 0,30 & 0,60 & 2,82 & 0,53 & 0,03 & 3,41 & 0,05 & 0,32 & 0,01 & 0,00 & 0,23 & 0,01 & 0,37 & 0,00 \\
\hline 2 & $\begin{array}{l}\text { nov/ } \\
12\end{array}$ & & & & & & & & & & & & & & & & & & & \\
\hline 3 & $\begin{array}{l}\text { nov/ } \\
12\end{array}$ & & & & & & & & & & & & & & & & & & & \\
\hline
\end{tabular}




\section{Apêndice V.Teste de confiabilidade}

Para análise de confiabilidade foi utilizado o software Acquachem, versão 2011.1.

\begin{tabular}{|c|c|c|c|c|c|c|c|}
\hline \multicolumn{8}{|l|}{ nov/11 } \\
\hline Check & limites & $A$ & $B$ & C & D & $E$ & $F$ \\
\hline Balance $(C-A) /(C+A) * 100$ & $<10 \%$ & $-0,06$ & 33,46 & 15,82 & 61,84 & $-8,93$ & 5,05 \\
\hline $\mathrm{K}+/(\mathrm{Na}++\mathrm{K}+)$ & $<20 \%$ & 54 & 7 & 7 & 5 & 52 & 21 \\
\hline $\mathrm{Mg}++/(\mathrm{Ca}+++\mathrm{Mg}++)$ & $<40 \%$ & 22 & 6 & 6 & 7 & 42 & 14 \\
\hline $\mathrm{Ca}++/(\mathrm{Ca}+++\mathrm{SO} 4--)$ & $>50 \%$ & 65 & 95 & 95 & 98 & 98 & 95 \\
\hline $\mathrm{Na}+/(\mathrm{Na}++\mathrm{Cl}-)$ & $>50 \%$ & 24 & 53 & 53 & 76 & 22 & 44 \\
\hline \multicolumn{8}{|l|}{$\mathrm{mar} / 12$} \\
\hline Balance $(C-A) /(C+A) * 100$ & $<10 \%$ & 36,99 & 55,6 & 47,26 & 82,09 & 44,37 & 45,14 \\
\hline $\mathrm{K}+/(\mathrm{Na}++\mathrm{K}+)$ & $<20 \%$ & 37 & 4 & 2 & 4 & 38 & 14 \\
\hline $\mathrm{Mg}++/(\mathrm{Ca}+++\mathrm{Mg}++)$ & $<40 \%$ & 27 & 12 & 19 & 10 & 55 & 22 \\
\hline $\mathrm{Ca}++/(\mathrm{Ca}+++\mathrm{SO} 4--)$ & $>50 \%$ & 81 & 97 & $n / a$ & 99 & 99 & 98 \\
\hline $\mathrm{Na}+/(\mathrm{Na}++\mathrm{Cl}-)$ & $>50 \%$ & 37 & 64 & 74 & 82 & 30 & 56 \\
\hline$a b r / 12$ & & A & $B$ & $C$ & D & $E$ & $F$ \\
\hline Balance $(C-A) /(C+A) * 100$ & $<10 \%$ & 6,62 & $-2,91$ & 0,09 & 13,05 & $-0,17$ & 14,51 \\
\hline $\mathrm{K}+/(\mathrm{Na}++\mathrm{K}+)$ & $<20 \%$ & 34 & 19 & 23 & 10 & 66 & 25 \\
\hline $\mathrm{Mg}++/(\mathrm{Ca}+++\mathrm{Mg}++)$ & $<40 \%$ & 12 & 18 & 35 & 7 & 34 & 30 \\
\hline $\mathrm{Ca}++/(\mathrm{Ca}+++\mathrm{SO} 4--)$ & $>50 \%$ & 94 & 97 & 98 & 100 & 98 & 99 \\
\hline $\mathrm{Na}+/(\mathrm{Na}++\mathrm{Cl}-)$ & $>50 \%$ & 49 & 64 & 59 & 79 & 13 & 23 \\
\hline & & & & & & & \\
\hline
\end{tabular}




\begin{tabular}{|c|c|c|c|c|c|c|c|}
\hline jul/12 & & P2 & P3 & C & $\mathrm{D}$ & $\mathrm{E}$ & $\mathrm{F}$ \\
\hline Balance $(C-A) /(C+A) * 100$ & $<10 \%$ & 8,24 & 19,84 & $-9,91$ & 1,62 & $-5,05$ & 8,95 \\
\hline $\mathrm{K}+/(\mathrm{Na}++\mathrm{K}+)$ & $<20 \%$ & 85 & 77 & 13 & 2 & 80 & 23 \\
\hline $\mathrm{Mg}++/(\mathrm{Ca}+++\mathrm{Mg}++)$ & $<40 \%$ & 39 & 24 & 33 & 26 & 48 & 36 \\
\hline $\mathrm{Ca}++/(\mathrm{Ca}+++\mathrm{SO} 4--)$ & $>50 \%$ & 92 & 94 & 99 & 96 & 99 & 91 \\
\hline \multirow[t]{2}{*}{$\mathrm{Na}+/(\mathrm{Na}++\mathrm{Cl}-)$} & $>50 \%$ & 26 & 29 & 53 & 91 & 11 & 34 \\
\hline & & $\mathrm{H}$ & $\mathrm{J}$ & $L$ & M1 & $N$ & 0 \\
\hline Balance $(C-A) /(C+A) * 100$ & $<10 \%$ & $-6,24$ & $-3,31$ & $-25,92$ & 5,45 & 3,73 & 1,42 \\
\hline $\mathrm{K}+/(\mathrm{Na}++\mathrm{K}+)$ & $<20 \%$ & 11 & 80 & 74 & 60 & 9 & 13 \\
\hline $\mathrm{Mg}++/(\mathrm{Ca}+++\mathrm{Mg}++)$ & $<40 \%$ & 29 & 19 & 81 & 18 & 11 & 29 \\
\hline $\mathrm{Ca}++/(\mathrm{Ca}+++\mathrm{SO} 4--)$ & $>50 \%$ & 100 & 99 & 99 & 100 & 98 & 99 \\
\hline $\mathrm{Na}+/(\mathrm{Na}++\mathrm{Cl}-)$ & $>50 \%$ & 32 & 29 & 10 & 39 & 37 & 90 \\
\hline nov/12 & & P1 & $A$ & $B$ & $D$ & $E$ & $F$ \\
\hline Balance $(C-A) /(C+A) * 100$ & $<10 \%$ & 80,52 & $-8,51$ & 10,69 & $-2,57$ & 26 & 53,6 \\
\hline $\mathrm{K}+/(\mathrm{Na}++\mathrm{K}+)$ & $<20 \%$ & 54 & 42 & 1 & 82 & 19 & 71 \\
\hline $\mathrm{Mg}++/(\mathrm{Ca}+++\mathrm{Mg}++)$ & $<40 \%$ & 24 & 27 & 13 & 51 & 34 & 11 \\
\hline $\mathrm{Ca}++/(\mathrm{Ca}+++\mathrm{SO} 4--)$ & $>50 \%$ & 95 & 51 & 97 & 99 & 89 & 99 \\
\hline \multirow[t]{2}{*}{$\mathrm{Na}+/(\mathrm{Na}++\mathrm{Cl}-)$} & $>50 \%$ & 59 & 29 & 94 & 13 & 40 & 25 \\
\hline & & $\mathrm{J}$ & K & M1 & 0 & & \\
\hline Balance $(C-A) /(C+A) * 100$ & $<10 \%$ & 71,96 & 8,51 & 13,97 & 80,52 & & \\
\hline $\mathrm{K}+/(\mathrm{Na}++\mathrm{K}+)$ & $<20 \%$ & 9 & 43 & 9 & 54 & & \\
\hline $\mathrm{Mg}++/(\mathrm{Ca}+++\mathrm{Mg}++)$ & $<40 \%$ & 12 & 20 & 26 & 24 & & \\
\hline $\mathrm{Ca}++/(\mathrm{Ca}+++\mathrm{SO} 4--)$ & $>50 \%$ & 99 & 100 & 98 & 95 & & \\
\hline $\mathrm{Na}+/(\mathrm{Na}++\mathrm{Cl}-)$ & $>50 \%$ & 89 & 51 & 92 & 59 & & \\
\hline
\end{tabular}


Apêndice VI. Descrição da litologia observada nas sondagens.

\begin{tabular}{|c|c|}
\hline \multicolumn{2}{|l|}{ Poço A } \\
\hline Profundidade $(\mathrm{m})$ & Descrição \\
\hline $0,00-1,00$ & Presença de matéria orgânica, mal selecionado, cor preto \\
\hline $1,00-2,00$ & Presença de menos matéria orgânica, presença de areia fina \\
\hline $2,00-4,00$ & Material arenoso e argiloso, marrom/ocre \\
\hline $4,00-4,20$ & Material arenoso e argiloso/siltoso \\
\hline
\end{tabular}

\begin{tabular}{|c|c|}
\hline \multicolumn{2}{|l|}{ Poço B } \\
\hline Profundidade $(\mathrm{m})$ & Descrição \\
\hline $0,00-1,00$ & Presença de matéria orgânica, mal selecionado, cor preto \\
\hline $1,00-3,00$ & Presença de menos matéria orgânica, presença de areia fina \\
\hline $3,00-4,00$ & Material arenoso, marrom/ocre \\
\hline $4,00-5,00$ & Material arenoso e argiloso, marrom/ocre \\
\hline $5,00-6,40$ & Material arenoso e argiloso/ siltoso \\
\hline
\end{tabular}

\begin{tabular}{|c|c|}
\hline \multicolumn{2}{|l|}{ Poço C } \\
\hline Profundidade $(\mathrm{m})$ & Descrição \\
\hline $0,00-1,00$ & Presença de matéria orgânica, mal selecionado, cor preto \\
\hline $1,00-3,00$ & Presença de menos matéria orgânica, presença de areia fina \\
\hline $3,00-4,00$ & Material arenoso, marrom/ocre \\
\hline $4,00-5,00$ & Material arenoso e argiloso, marrom/ocre \\
\hline $5,00-6,60$ & Material arenoso e argiloso/ siltoso \\
\hline
\end{tabular}

\begin{tabular}{|l|l|l|}
\cline { 2 - 3 } \multicolumn{2}{|l|}{} & \multicolumn{2}{l|}{ Poço D } & \multicolumn{2}{l|}{ Descrição } \\
\cline { 2 - 3 } \multicolumn{1}{l|}{} & Profundidade $(\mathrm{m})$ & $\begin{array}{l}\text { Presença de matéria orgânica, mal selecionado, cor marrom escuro } \\
- \text { misturado pelo arado para plantação de cana-de-açúcar }\end{array}$ \\
\hline & $0,00-1,00$ & Presença de menos matéria orgânica, presença de areia fina \\
\hline $1,00-3,00$ & Material arenoso, marrom/ocre \\
\hline $3,00-4,00$ & Material arenoso e argiloso, marrom/ocre \\
\hline $4,00-5,00$ & Material arenoso e argiloso/ siltoso ligeiramente compacto \\
\hline $5,00-7,50$ &
\end{tabular}




\begin{tabular}{|c|c|}
\hline \multicolumn{2}{|l|}{ Poço E } \\
\hline Profundidade (m) & Descrição \\
\hline $0,00-1,00$ & Presença de matéria orgânica, mal selecionado, cor preto \\
\hline $1,00-3,00$ & Presença de menos matéria orgânica, presença de areia fina \\
\hline $3,00-4,00$ & Presença de material arenoso, marrom/ocre \\
\hline $4,00-5,75$ & Material arenoso e argiloso/ siltoso, marrom/ocre \\
\hline
\end{tabular}

\begin{tabular}{|c|c|}
\hline \multicolumn{2}{|l|}{ Poço F } \\
\hline Profundidade (m) & Descrição \\
\hline $0,00-1,00$ & Presença de matéria orgânica, mal selecionado, cor preto \\
\hline $1,00-3,74$ & Material arenoso e argiloso/ siltoso \\
\hline
\end{tabular}

\begin{tabular}{|l|l|l|}
\cline { 2 - 3 } \multicolumn{1}{l|}{} & \multicolumn{2}{l|}{ Poço G } \\
\cline { 2 - 3 } \multicolumn{1}{l|}{} & Profundidade $(\mathrm{m})$ & Descrição \\
\hline & $0,00-1,00$ & Presença de matéria orgânica, mal selecionado, cor preto \\
\hline $1,00-4,00$ & Presença de menos matéria orgânica, presença de areia fina \\
\hline $4,00-5,00$ & Material arenoso e argiloso, marrom/ocre \\
\hline $5,00-6,20$ & Material arenoso e argiloso/ siltoso \\
\hline
\end{tabular}

\begin{tabular}{|l|l|l|}
\cline { 2 - 3 } \multicolumn{1}{l|}{} & \multicolumn{2}{l|}{ Poço H } \\
\cline { 2 - 3 } \multicolumn{1}{l|}{} & Profundidade $(\mathrm{m})$ & Descrição \\
\hline & $0,00-1,00$ & $\begin{array}{l}\text { Presença de matéria orgânica, areia fina e média com grânulos, cor } \\
\text { marrom escuro }\end{array}$ \\
\hline $1,00-3,00$ & $\begin{array}{l}\text { Presença de menos matéria orgânica, presença de areia fina a } \\
\text { grossa, marrom escuro }\end{array}$ \\
\hline & $3,00-4,00$ & Material arenoso, marrom/ocre \\
\hline & $4,00-6,00$ & Material arenoso ocre e argiloso/ siltoso claro. \\
\hline
\end{tabular}

\begin{tabular}{|c|c|}
\hline \multicolumn{2}{|l|}{ Poçol } \\
\hline Profundidade $(\mathrm{m})$ & Descrição \\
\hline $0,00-1,00$ & Presença de matéria orgânica, mal selecionado, cor marrom \\
\hline $1,00-2,10$ & Material arenoso e argiloso/ siltoso \\
\hline
\end{tabular}




\begin{tabular}{|c|c|}
\hline \multicolumn{2}{|l|}{ Poço J e K } \\
\hline Profundidade (m) & Descrição \\
\hline $0,00-1,00$ & Presença de matéria orgânica, mal selecionado, cor marrom \\
\hline $1,00-3,00$ & $\begin{array}{l}\text { Presença de menos de matéria orgânica, presença de areia média a } \\
\text { fina }\end{array}$ \\
\hline $3,00-4,00$ & Material arenoso fino, marrom/ocre \\
\hline $4,00-5,51$ & Material arenoso e argiloso/ siltoso, marrom/ocre, molhado \\
\hline
\end{tabular}

\begin{tabular}{|c|c|}
\hline \multicolumn{2}{|l|}{ Poço L } \\
\hline Profundidade $(\mathrm{m})$ & Descrição \\
\hline $0,00-1,00$ & Presença de matéria orgânica, mal selecionado, cor marrom/ cinza \\
\hline $1,00-2,00$ & $\begin{array}{l}\text { Presença de menos matéria orgânica, presença de areia fina, } \\
\text { média e grossa }\end{array}$ \\
\hline $2,00-3,00$ & Presença de material arenoso, marrom/ocre \\
\hline $3,00-4,00$ & Material arenoso e siltoso, \\
\hline $4,00-4,90$ & Material arenoso e siltoso/argiloso claro \\
\hline
\end{tabular}

\begin{tabular}{|c|c|}
\hline \multicolumn{2}{|l|}{ Poço N, R e S } \\
\hline Profundidade (m) & Descrição \\
\hline $0,00-2,00$ & $\begin{array}{l}\text { Presença de matéria orgânica, mal selecionado areia fina média e } \\
\text { grossa, presença de silte/argila, cor cinza escuro/ preto }\end{array}$ \\
\hline
\end{tabular}

\begin{tabular}{|c|c|}
\hline \multicolumn{2}{|l|}{ Poços 1,2 e 3} \\
\hline Profundidade $(\mathrm{m})$ & Descrição \\
\hline $0,00-2,00$ & $\begin{array}{l}\text { Presença de matéria orgânica, mal selecionado areia fina média e } \\
\text { grossa, presença de silte/argila, cor cinza escuro/ preto }\end{array}$ \\
\hline
\end{tabular}

\begin{tabular}{|c|c|}
\hline \multicolumn{2}{|l|}{ Poço 70} \\
\hline Profundidade $(\mathrm{m})$ & Descrição \\
\hline $0,00-2,00$ & $\begin{array}{l}\text { Presença de silte, pouca areia, preto, presença restos vegetais e } \\
\text { matéria orgânica }\end{array}$ \\
\hline
\end{tabular}




\begin{tabular}{|l|l|l|}
\hline $2,00-12,00$ & presença de silte / areia fina \\
\hline $12,00-13,50$ & $\begin{array}{l}\text { Argila cinza plástica, com pequenos bolsões/ veios de areia fina/ } \\
\text { folheada }\end{array}$ \\
\hline $15,50-16,50$ & $\begin{array}{l}\text { Argila plástica, pouca areia fina, bolsões pequenos de coloração } \\
\text { avermelhada, ocre e cinza claro, compacta. }\end{array}$ \\
\hline
\end{tabular}

\begin{tabular}{|c|c|}
\hline \multicolumn{2}{|l|}{ Poço 80} \\
\hline Profundidade $(\mathrm{m})$ & Descrição \\
\hline $0,00-2,00$ & $\begin{array}{l}\text { Presença de silte, pouca areia, presença restos vegetais e matéria } \\
\text { orgânica }\end{array}$ \\
\hline $2,00-11,00$ & Presença de silte/areia fina \\
\hline $11,00-14,00$ & $\begin{array}{l}\text { Presença de pedregulhos centimétricos (aprox. } 3 \mathrm{~cm} \text { ) cor ocre, } \\
\text { desagregado. }\end{array}$ \\
\hline $14,00-16,50$ & Silte, argila vermelha a ocre, presença de areia média branca \\
\hline $16,50-17,50$ & $\begin{array}{l}\text { Argila vermelha plástica folheada, com pequenos bolsões de } \\
\text { silte/areia ocre a branca, bolsões de argila branca }\end{array}$ \\
\hline 18,00 & $\begin{array}{l}\text { Argila plástica, pouca areia fina, bolsões pequenos de coloração } \\
\text { avermelhada, ocre e cinza claro, compacta }\end{array}$ \\
\hline
\end{tabular}

\begin{tabular}{|l|l|l|}
\cline { 2 - 3 } \multicolumn{2}{|l|}{} & \multicolumn{2}{l|}{ Poço 90 e 100} & Descrição \\
\cline { 2 - 3 } & Profundidade $(\mathrm{m})$ & Presença de silte e de areia; cor branca/creme \\
\hline $0,00-2,00$ & $\begin{array}{l}\text { Presença de silte, argila vermelho escuro com pequenas porções } \\
\text { brancas e ocre }\end{array}$ \\
\hline $10-11$ & $\begin{array}{l}\text { Presença de pedregulhos centimétricos (aprox. } 3 \mathrm{~cm} \text { ) cor ocre, } \\
\text { desagregado }\end{array}$ \\
\hline $11-11,50$ & Silte, argila vermelha a ocre, presença de areia média branca \\
\hline $11,50-12,00$ & Argila vermelha plástica folheada, com pequenos bolsões de \\
\hline
\end{tabular}




\begin{tabular}{|l|l|l|}
\hline & & silte/areia ocre a branca; bolsões de argila branca \\
\hline 14 e 12 & $\begin{array}{l}\text { Argila plástica, pouca areia fina, bolsões pequenos de coloração } \\
\text { avermelhada, ocre e cinza claro, compacta }\end{array}$ \\
\hline
\end{tabular}

\begin{tabular}{|l|l|l|}
\hline \multicolumn{2}{|l|}{ Poço 110 e 120} & Descrição \\
\cline { 2 - 3 } & Profundidade $(\mathrm{m})$ & $\begin{array}{l}\text { Presença de silte, pouca areia, preto, presença restos vegetais e } \\
\text { matéria orgânica }\end{array}$ \\
\hline $0,00-2,00$ & $\begin{array}{l}\text { Argila cinza plástica, com pequenos bolsões/ veios de areia fina/ } \\
\text { folheada }\end{array}$ \\
\hline $7,00-4,00$ & $\begin{array}{l}\text { Argila plástica, pouca areia fina, bolsões pequenos de coloração } \\
\text { avermelhada, compacta. }\end{array}$ \\
\hline
\end{tabular}

\begin{tabular}{|l|l|l|}
\hline \multicolumn{2}{|l|}{ Poço U } & \multicolumn{2}{l|}{ Descrição } \\
\cline { 2 - 3 } & Profundidade $(\mathrm{m})$ & $\begin{array}{l}\text { Presença de silte, pouca areia, preto, presença restos vegetais e } \\
\text { matéria orgânica }\end{array}$ \\
\hline $0,00-2,00$ & Presença de silte/ areia fina / argila/ silte \\
\hline
\end{tabular}

\begin{tabular}{|l|l|l|}
\hline \multicolumn{2}{|l|}{ Poço Q } \\
\cline { 2 - 3 } & Profundidade $(\mathrm{m})$ & Descrição \\
\hline $0,00-2,00$ & $\begin{array}{l}\text { Presença de silte, pouca areia, preto, presença restos vegetais e } \\
\text { matéria orgânica }\end{array}$ \\
\hline $2,00-5,70$ & Presença de silte/ areia fina / argila/ silte \\
\hline
\end{tabular}




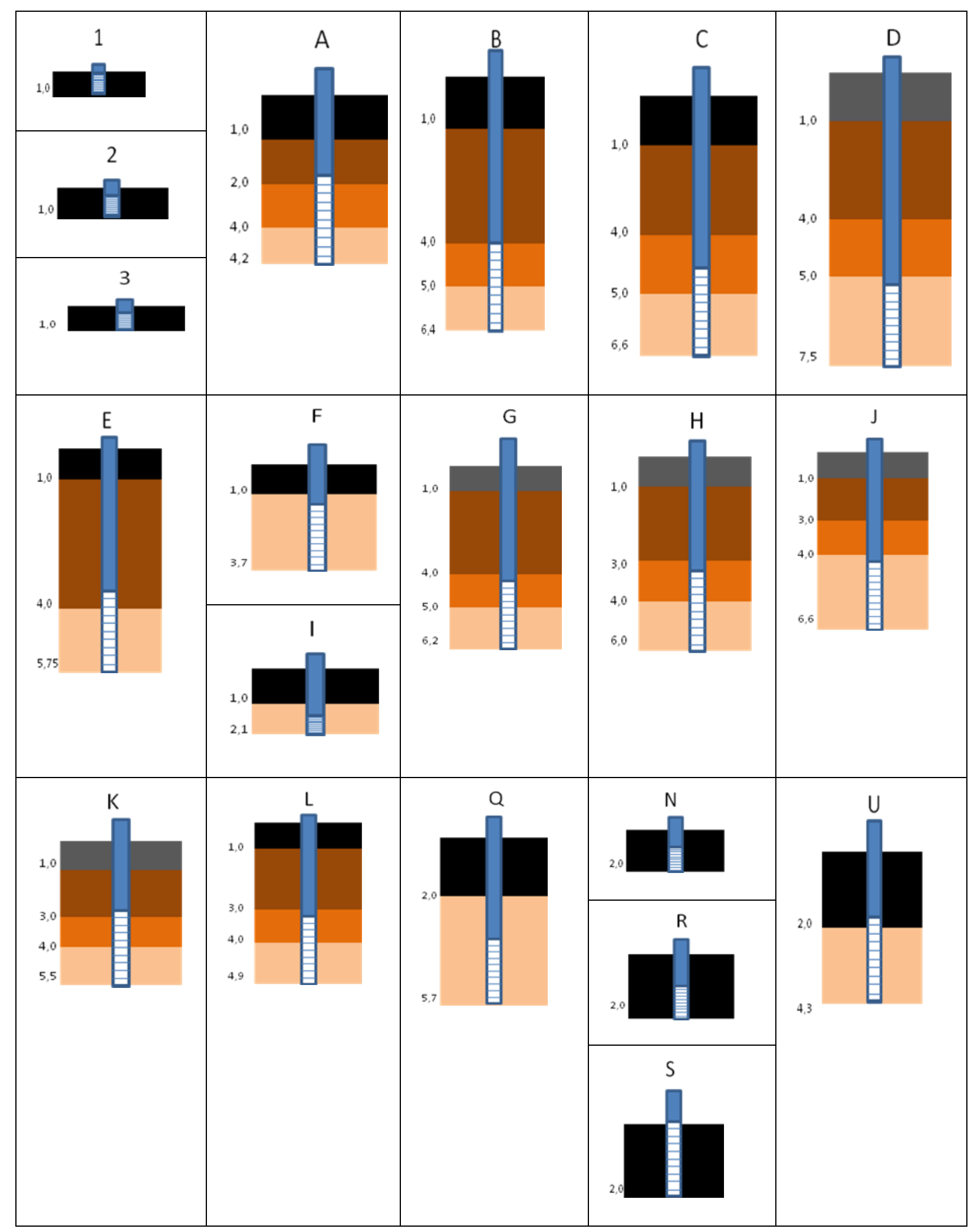




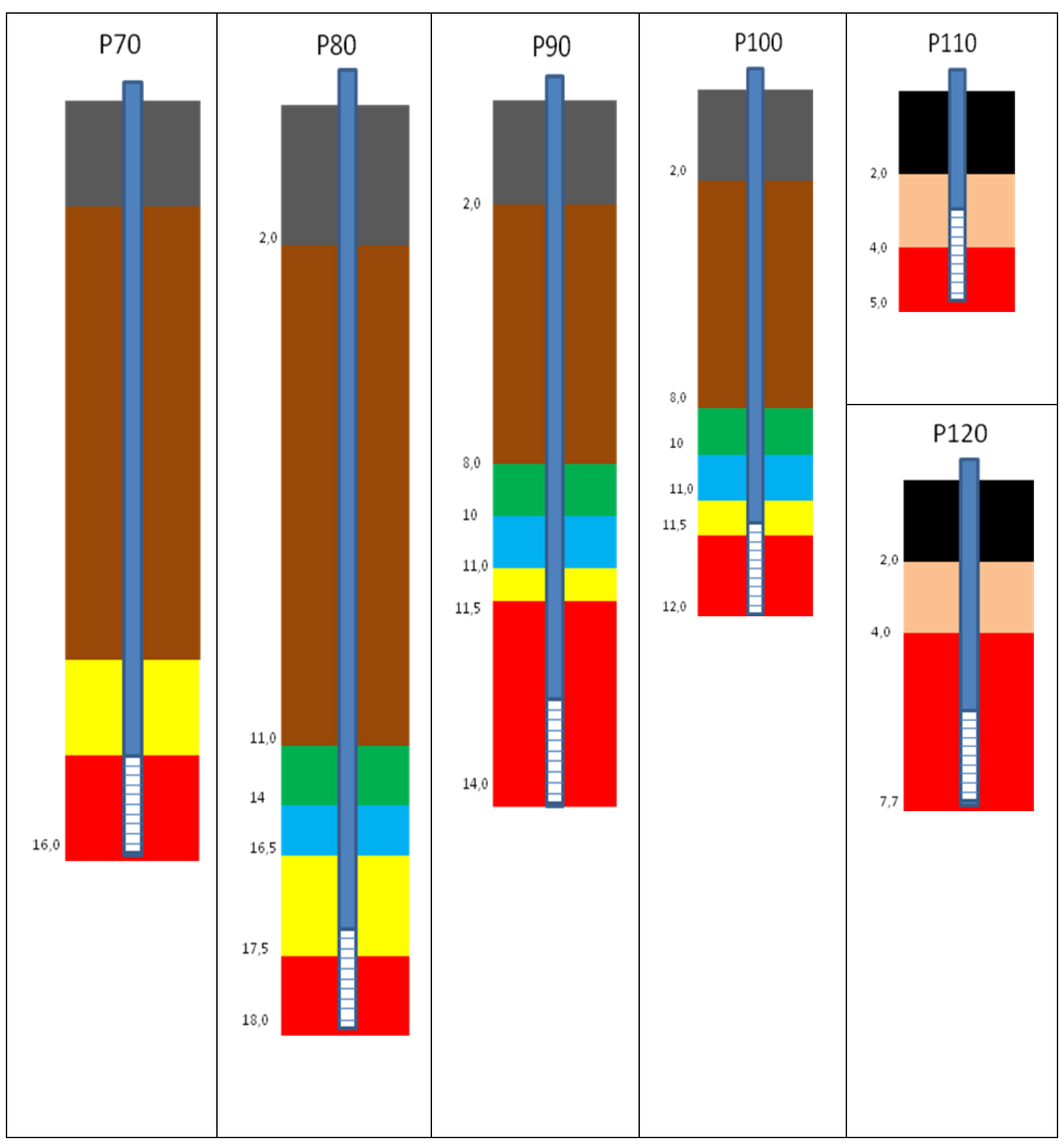


Apêndice VII. Dados de slug test

Poço P130

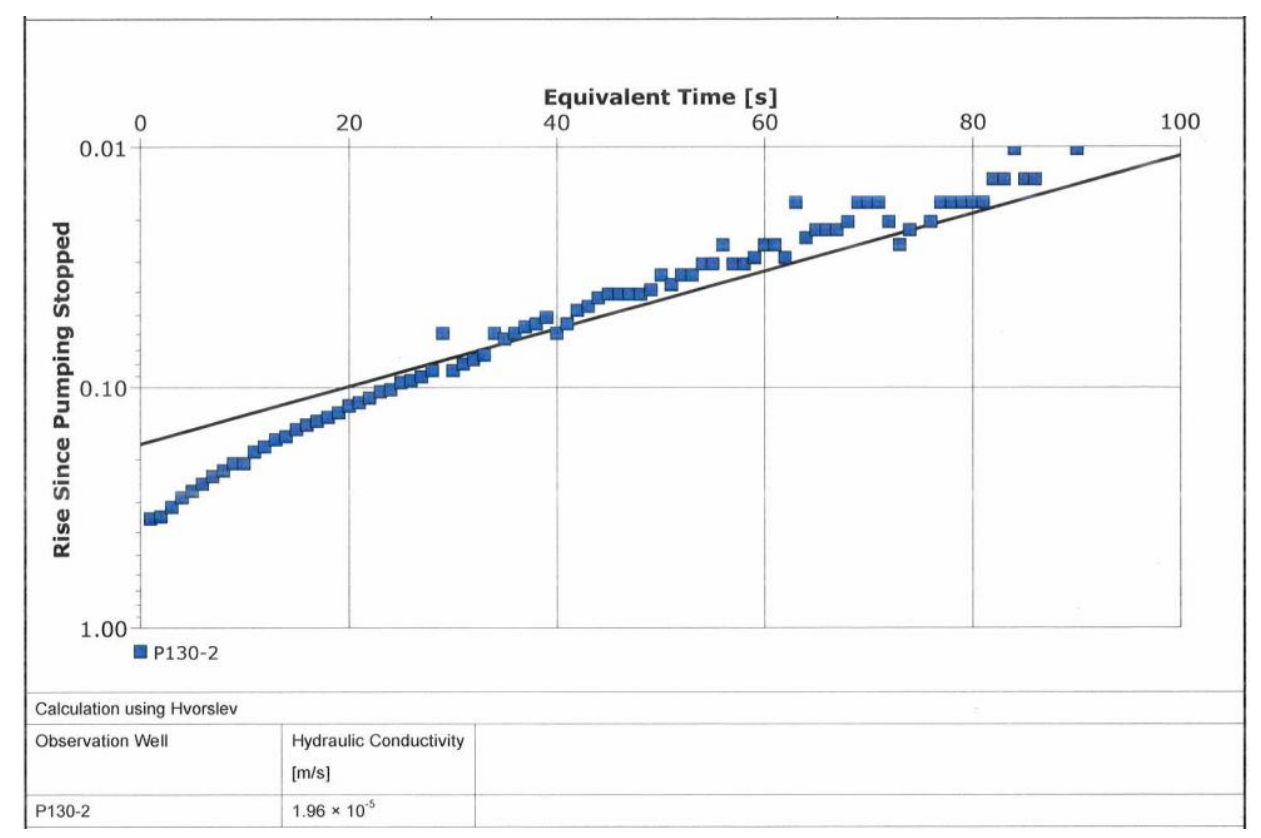

Poço P90

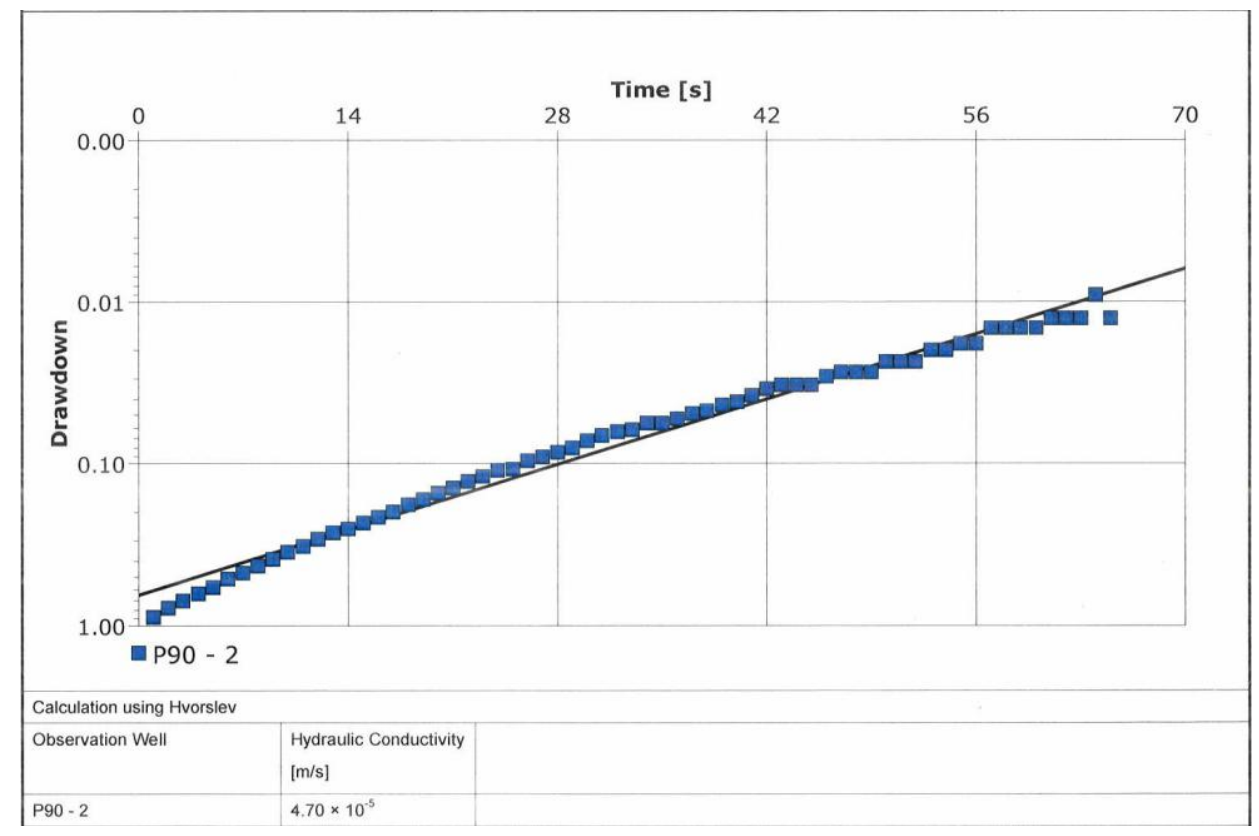

103 
Dados temporais do Slug test dos poços P130 e P90

\begin{tabular}{|c|c|c|c|c|c|c|c|c|}
\hline tempo & P130 & P90 & 43 & 4,907 & 13,54 & 86 & 4,888 & 13,275 \\
\hline 1 & 5,086 & 13,49 & 44 & 4,905 & 13,537 & 87 & 4,888 & 13,296 \\
\hline 2 & 5,083 & 13,523 & 45 & 4,904 & 13,535 & 88 & 4,875 & 13,312 \\
\hline 3 & 5,065 & 13,515 & 46 & 4,904 & 13,533 & 89 & 4,883 & 13,328 \\
\hline 4 & 5,049 & 13,512 & 47 & 4,904 & 13,525 & 90 & 4,883 & 13,343 \\
\hline 5 & 5,038 & 13,508 & 48 & 4,904 & 13,527 & 91 & 4,885 & 13,351 \\
\hline 6 & 5,028 & 13,505 & 49 & 4,903 & 13,525 & 92 & 4,886 & 13,362 \\
\hline 7 & 5,018 & 13,51 & 50 & 4,9 & 13,523 & 93 & 4,885 & 13,372 \\
\hline 8 & 5,01 & 13,505 & 51 & 4,902 & 13,522 & 94 & 4,885 & 13,38 \\
\hline 9 & 5,002 & 13,503 & 52 & 4,9 & 13,52 & 95 & 4,885 & 13,391 \\
\hline 10 & 5,002 & 13,502 & 53 & 4,9 & 13,525 & 96 & 4,885 & 13,398 \\
\hline 11 & 4,989 & 13,503 & 54 & 4,898 & 13,522 & 97 & 4,885 & 13,406 \\
\hline 12 & 4,984 & 13,977 & 55 & 4,898 & 13,518 & 98 & 4,885 & 13,412 \\
\hline 13 & 4,977 & 14,076 & 56 & 4,895 & 13,517 & 99 & 4,885 & 13,419 \\
\hline 14 & 4,974 & 13,696 & 57 & 4,898 & 13,492 & 100 & 4,885 & 13,424 \\
\hline 15 & 4,968 & 13,693 & 58 & 4,898 & 13,494 & 101 & 4,885 & 13,429 \\
\hline 16 & 4,964 & 13,675 & 59 & 4,897 & 13,492 & 102 & 4,885 & 13,43 \\
\hline 17 & 4,961 & 13,659 & 60 & 4,895 & 13,492 & 103 & 4,886 & 13,437 \\
\hline 18 & 4,958 & 13,648 & 61 & 4,895 & 13,492 & 104 & 4,885 & 13,44 \\
\hline 19 & 4,955 & 13,638 & 62 & 4,897 & 13,492 & 105 & 4,886 & 13,443 \\
\hline 20 & 4,95 & 13,628 & 63 & 4,89 & 13,492 & 106 & 4,885 & 13,446 \\
\hline 21 & 4,948 & 13,62 & 64 & 4,894 & 13,492 & 107 & 4,885 & 13,45 \\
\hline 22 & 4,945 & 13,612 & 65 & 4,893 & 13,492 & 108 & 4,885 & 13,453 \\
\hline 23 & 4,941 & 13,612 & 66 & 4,893 & 13,492 & 109 & 4,885 & 13,455 \\
\hline 24 & 4,94 & 13,599 & 67 & 4,893 & 13,494 & 110 & 4,885 & 13,456 \\
\hline 25 & 4,936 & 13,594 & 68 & 4,892 & 13,492 & 111 & 4,885 & 13,459 \\
\hline 26 & 4,935 & 13,587 & 69 & 4,89 & 13,492 & 112 & 4,885 & 13,459 \\
\hline 27 & 4,933 & 13,584 & 70 & 4,89 & 13,492 & 113 & 4,885 & 13,461 \\
\hline 28 & 4,93 & 13,578 & 71 & 4,89 & 13,492 & 114 & 4,885 & 13,463 \\
\hline 29 & 4,915 & 13,574 & 72 & 4,892 & 13,492 & 115 & 4,885 & 13,464 \\
\hline 30 & 4,93 & 13,571 & 73 & 4,895 & 13,494 & 116 & 4,885 & 13,466 \\
\hline 31 & 4,927 & 13,568 & 74 & 4,893 & 13,492 & 117 & 4,885 & 13,467 \\
\hline 32 & 4,925 & 13,565 & 75 & 4,877 & 13,492 & 118 & 4,885 & 13,469 \\
\hline 33 & 4,923 & 13,56 & 76 & 4,892 & 13,492 & 119 & 4,885 & 13,471 \\
\hline 34 & 4,915 & 13,558 & 77 & 4,89 & 12,94 & 120 & 4,885 & 13,472 \\
\hline 35 & 4,917 & 13,555 & 78 & 4,89 & 13,003 & 121 & 4,885 & 13,472 \\
\hline 36 & 4,915 & 13,551 & 79 & 4,89 & 13,06 & 122 & 4,883 & 13,472 \\
\hline 37 & 4,913 & 13,55 & 80 & 4,89 & 13,103 & 123 & 4,882 & 13,474 \\
\hline 38 & 4,912 & 13,546 & 81 & 4,89 & 13,139 & 124 & 4,882 & 13,475 \\
\hline 39 & 4,91 & 13,545 & 82 & 4,888 & 13,171 & 125 & 4,884 & 13,475 \\
\hline 40 & 4,915 & 13,543 & 83 & 4,89 & 13,207 & 126 & 4,884 & 13,475 \\
\hline 41 & 4,912 & 13,54 & 84 & 4,888 & 13,23 & 127 & 4,884 & 13,477 \\
\hline 42 & 4,908 & 13,525 & 85 & 4,886 & 13,255 & 128 & 4,882 & 13,477 \\
\hline
\end{tabular}




\begin{tabular}{|lll|}
\hline 129 & 4,884 & 13,477 \\
130 & 4,882 & 13,479 \\
131 & 4,882 & 13,479 \\
132 & 4,884 & 13,48 \\
133 & 4,882 & 13,48 \\
134 & 4,882 & 13,482 \\
135 & 4,882 & 13,482 \\
136 & 4,882 & 13,482 \\
137 & 4,882 & 13,482 \\
138 & 4,882 & 13,483 \\
139 & 4,882 & 13,483 \\
140 & 4,884 & 13,483 \\
141 & 4,884 & 13,485 \\
142 & 4,884 & 13,483 \\
143 & 4,884 & \\
144 & 4,882 & \\
145 & 4,884 & \\
146 & 4,882 & \\
147 & 4,882 & \\
148 & 4,882 & \\
149 & 4,882 & \\
150 & 4,882 & \\
151 & 4,882 & \\
152 & 4,882 & \\
153 & 4,882 & \\
154 & 4,884 & \\
155 & 4,882 & \\
156 & 4,882 & \\
157 & 4,882 & \\
158 & 4,882 & \\
159 & 4,882 & \\
160 & 4,884 & \\
161 & 4,882 & \\
162 & 4,882 & \\
163 & 4,882 & \\
& & \\
\hline
\end{tabular}




\section{ANEXOS}

Anexo I. Mapa Geológico - Folha Rio Claro.

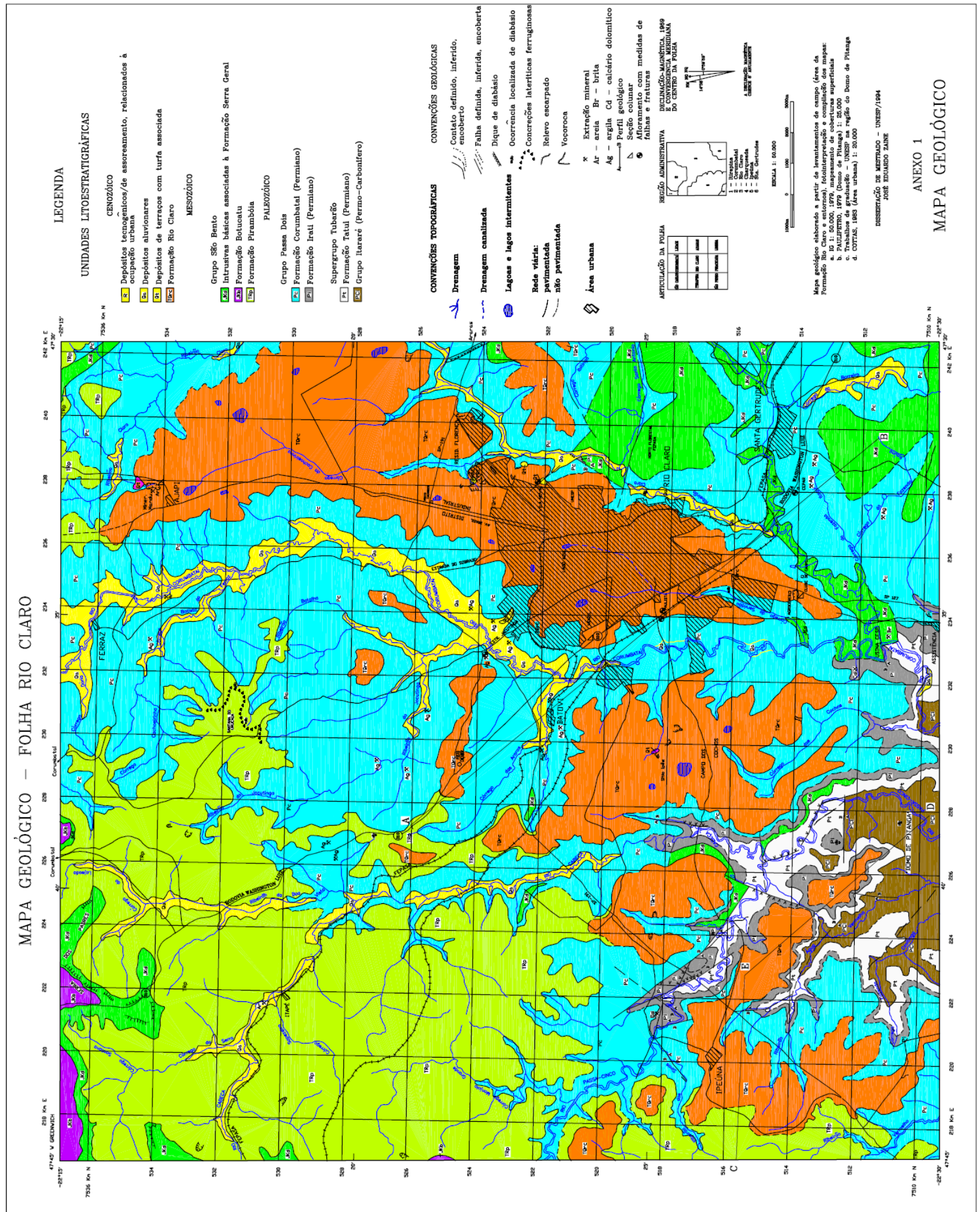


Anexo II. MApa topográfico - Rio claro, sp.
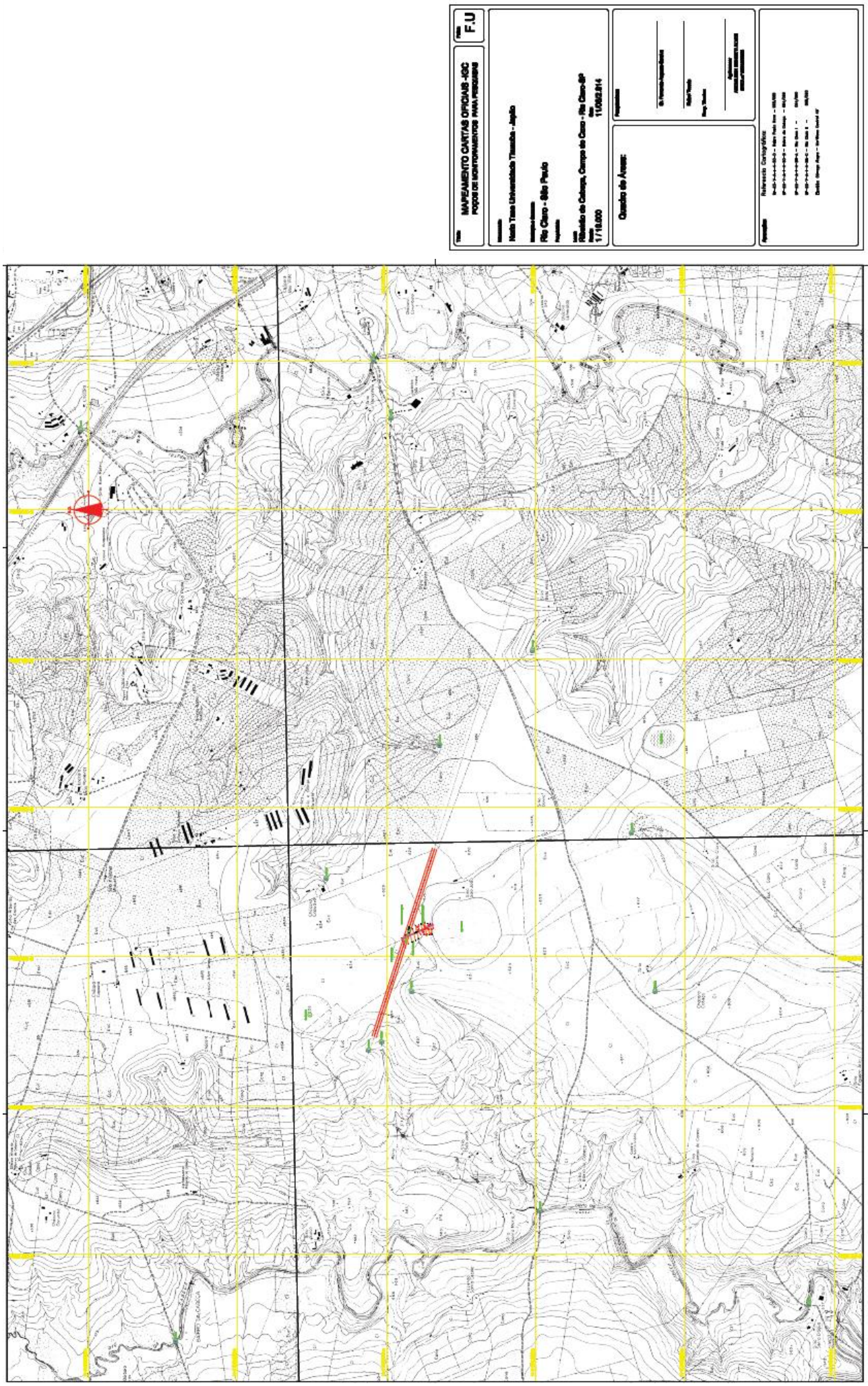
Anexo III. Localização dos poços de monitoramento

Localização dos poços na área de cana-de-açúcar

\begin{tabular}{|l|l|l|l|l|l|}
\hline Poço & Latitude & Longitude & Cota (m) & Prof. (m) & Filtro (m) \\
\hline C & E 7517752,01 & 23 K229168,73 & 624,22 & 6,63 & $6,02-4,02$ \\
\hline D & E 7517775,99 & 23 K229173,99 & 625,26 & 7,49 & $7,32-5,32$ \\
\hline E & E 7517729,14 & 23 K229188,40 & 622,50 & 5,74 & $5,40-3,40$ \\
\hline H & E 7517745,43 & 23 K229202,97 & 622,77 & 5,17 & $2,67-0,67$ \\
\hline L & E 7517726,11 & 23 K229185,39 & 622,69 & 4,90 & $4,95-3,95$ \\
\hline M1 & E 7517783,04 & 23 K229189,31 & 624,99 & 17,09 & $19,79-17,79$ \\
\hline M2 & E 7517783,11 & 23 K229192,68 & 625,06 & 6,88 & $6,41-4,41$ \\
\hline
\end{tabular}

Localização dos poços na lagoa

\begin{tabular}{|l|l|l|l|l|l|}
\hline Poço & Latitude & Longitude & Cota (m) & Prof. (m) & Filtro (m) \\
\hline 1 & E 7517689,55 & 23 K229206,35 & 619,55 & 0,71 & $0,88-0,00$ \\
\hline 2 & E 7517682,97 & 23 K229177,98 & 620,41 & 0,96 & $1,03-0,00$ \\
\hline 3 & E 7517683,97 & 23 K229139,83 & 621,02 & 0,97 & $0,98-0,00$ \\
\hline Lago & E 7517970,81 & 23 K229323,66 & 619,14 & 2,00 & $2,00-1,00$ \\
\hline I & E 7517705,66 & 23 K229168,89 & 621,73 & 2,10 & $2,20-1,20$ \\
\hline A & E 7517707,61 & 23 K229176,00 & 621,96 & 4,20 & $4,15-2,15$ \\
\hline F & E 7517693,49 & 23 K229203,32 & 621,36 & 3,72 & $3,67-2,67$ \\
\hline
\end{tabular}

Localização dos poços na área de eucaliptos

\begin{tabular}{|l|l|l|l|l|l|}
\hline Poço & Latitude & Longitude & Cota (m) & Prof. (m) & Filtro (m) \\
\hline B & E 7517735,00 & 23 K229178,08 & 623,03 & 6,40 & $5,81-3,81$ \\
\hline G & E 7517731,78 & 23 K229137,27 & 623,73 & 6,20 & $6,30-4,30$ \\
\hline J & E 7517746,65 & 23 K229156,41 & 623,62 & 5,51 & $5,36-4,36$ \\
\hline
\end{tabular}




\begin{tabular}{|l|l|l|l|l|l|}
\hline K & E 7517714,52 & 23 K229140,31 & 622,43 & 4,43 & $4,49-2,99$ \\
\hline N & E 7517694,07 & 23 K229134,74 & 621,10 & 1,60 & $1,56-0,56$ \\
\hline O & E 7517753,13 & 23 K229135,71 & 623,73 & 18,38 & $18,79-16,79$ \\
\hline P20 & E 7517891,20 & 23 K229133,10 & 628,17 & 10,69 & $10,60-9,60$ \\
\hline P30 & E 7517692,29 & 23 K229091,30 & 632,44 & 16,00 & $15,90-14,90$ \\
\hline P40 & E 7517608,72 & 23 K229161,27 & 626,26 & 11,12 & $11,00-10,00$ \\
\hline P50 & - & - & - & 10,34 & $10,30-9,30$ \\
\hline P60 & - & - & - & 6,96 & $6,50-5,50$ \\
\hline P70 & E 7517839,79 & 23 K229115,81 & 629,41 & 16,05 & $13,00-16,00$ \\
\hline P80 & E 7517616,42 & 23 K229068,88 & 632,46 & 19,17 & $16,00-19,00$ \\
\hline P90 & E 7517659,43 & 23 K229271,25 & 627,39 & 14,05 & $12,00-14,00$ \\
\hline P100 & E 7517660,48 & 23 K229271,05 & 627,41 & 11,98 & $8,00-10,00$ \\
\hline P110 & E 7517749,15 & 23 K229362,00 & 621,27 & 4,99 & $4,00-5,00$ \\
\hline P120 & E 7517748,70 & 23 K229362,09 & 621,27 & 7,70 & $6,00-8,00$ \\
\hline PQ & E 7517721,41 & 23 K229367,92 & 621,33 & 5,78 & $5,60-4,60$ \\
\hline PR & - & - & - & 2,54 & $2,50-1,50$ \\
\hline PS & - & - & - & 2,79 & $2,70-1,70$ \\
\hline PU & E 7517809,35 & 23 K229.331,82 & 620,78 & 4,36 & $4,30-3,30$ \\
\hline & & & & & \\
\hline
\end{tabular}


Anexo IV. Descrição do material pedológico

Descrição do material pedológico/geológico próximo à lagoa

\begin{tabular}{|l|l|l|l|}
\hline Camada & Profundidade (m) & $\begin{array}{l}\text { Tipo de } \\
\text { material }\end{array}$ & Descrição \\
\hline 1 & $0-2$ & Areia & $\begin{array}{l}\text { Escura, fina, presença de argila e calcário, } \\
\text { matéria orgânica }\end{array}$ \\
\cline { 2 - 4 } & $2-3$ & $\begin{array}{l}\text { Areia/ } \\
\text { argila }\end{array}$ & $\begin{array}{l}\text { Marrom, solta, presença de argila, } \\
\text { plasticidade média }\end{array}$ \\
\hline 3 & $3-4$ & $\begin{array}{l}\text { Areia/ } \\
\text { argila }\end{array}$ & $\begin{array}{l}\text { Alto conteúdo de argila com plasticidade } \\
\text { média, marrom claro }\end{array}$ \\
\hline 3 & $4-5$ & Argila & Argila clara, marrom claro/cinza \\
\hline
\end{tabular}

Descrição do material pedológico/geológico da sondagem do poço 70

\begin{tabular}{|l|l|}
\hline Poço 70/Profundidade (m) & Descrição \\
\hline $0,00-2,00$ & $\begin{array}{l}\text { Solo bem desenvolvido, preto, com presença de silte, pouca } \\
\text { areia, presença de restos vegetais e matéria orgânica }\end{array}$ \\
\hline $2,00-12,00$ & $\begin{array}{l}\text { Presença de silte/ areia fina, vermelho escuro com pequenas } \\
\text { porções brancas e ocre }\end{array}$ \\
\hline $12-13,50$ & $\begin{array}{l}\text { Argila cinza plástica, com pequenos bolsões/veios de areia } \\
\text { fina/ folheada }\end{array}$ \\
\hline $13,50-16,50$ & $\begin{array}{l}\text { Argila plástica, pouca areia fina, bolsões pequenos de } \\
\text { coloração avermelhada, ocre e cinza claro, compacta }\end{array}$ \\
\hline
\end{tabular}

Descrição do material pedológico/geológico da sondagem do poço 80

\begin{tabular}{|l|l|}
\hline Poço 80/Profundidade (m) & Descrição \\
\hline $0,00-2,00$ & $\begin{array}{l}\text { Solo bem desenvolvido, presença de silte, pouca areia, } \\
\text { preto, presença restos vegetais e matéria orgânica }\end{array}$ \\
\hline $2,00-11,00$ & $\begin{array}{l}\text { Presença de silte/areia fina, vermelho escuro com pequenas } \\
\text { porções brancas e ocre }\end{array}$ \\
\hline
\end{tabular}




\begin{tabular}{|l|l|}
\hline $11-14$ & Cascalho (aprox. $3 \mathrm{~cm}$ ) de cor ocre, desagregado. \\
\hline $14-16,50$ & Silte, argila vermelha a ocre, presença de areia média branca \\
\hline $16,50-17,50$ & $\begin{array}{l}\text { Argila vermelha plástica folheada, com pequenos bolsões de } \\
\text { silte/areia ocre a branca, bolsões de argila branca }\end{array}$ \\
\hline 18,00 & $\begin{array}{l}\text { Argila plástica, pouca areia fina, bolsões pequenos de } \\
\text { coloração avermelhada, ocre e cinza claro, compacta }\end{array}$ \\
\hline
\end{tabular}

Descrição do material pedológico/geológico da sondagem do poço 90 e 100

\begin{tabular}{|l|l|}
\hline $\begin{array}{l}\text { Poço } \mathbf{9 0} \text { e 100/Profundidade } \\
\text { (m) }\end{array}$ & Descrição \\
\hline $0-2$ & Silte e areia de cor branca/creme \\
\hline $\begin{array}{l}2-8 \text { presença de silte/ areia } \\
\text { fina }\end{array}$ & $\begin{array}{l}\text { Silte e argila, de cor vermelha escura, com pequenas porções } \\
\text { brancas e ocre }\end{array}$ \\
\hline $10-11$ & Cascalho (aprox. $3 \mathrm{~cm}$ ) de cor ocre, desagregado \\
\hline $11-12$ & Silte, argila vermelha a ocre, presença de areia média branca \\
\hline 14 e 12 & $\begin{array}{l}\text { Argila vermelha plástica folheada, com pequenos bolsões de } \\
\text { silte/areia ocre a branca; bolsões de argila branca }\end{array}$ \\
\hline & $\begin{array}{l}\text { Argila plástica, pouca areia fina, bolsões pequenos de } \\
\text { coloração avermelhada, ocre e cinza claro, compacta }\end{array}$ \\
\hline
\end{tabular}

Descrição do material pedológico/geológico da sondagem do poço 110 e 120

\begin{tabular}{|l|l|}
\hline $\begin{array}{l}\text { Poço } 110 \text { e 120/ Profundidade } \\
\text { (m) }\end{array}$ & Descrição \\
\hline $0,00-2,00$ & $\begin{array}{l}\text { Presença de silte, pouca areia, preto, presença restos } \\
\text { vegetais e matéria orgânica }\end{array}$ \\
\hline $\begin{array}{l}\text { Poço } 110 \text { e 120/ Profundidade } \\
\text { (m) }\end{array}$ & Descrição \\
\hline $2,00-8,00$ & $\begin{array}{l}\text { Presença de silte/ areia fina, vermelho escuro com pequenas } \\
\text { porções brancas e ocre }\end{array}$ \\
\hline
\end{tabular}




\begin{tabular}{|l|l|}
\hline $8,50-9,50$ & $\begin{array}{l}\text { Argila cinza plástica, com pequenos bolsões/ veios de areia } \\
\text { fina/ folheada }\end{array}$ \\
\hline $9,50-10,50$ & $\begin{array}{l}\text { Argila plástica, pouca areia fina, bolsões pequenos de } \\
\text { coloração avermelhada, compacta }\end{array}$ \\
\hline
\end{tabular}

